\title{
Sequence Stratigraphic, Lithostratigraphic and Stable Isotope Analysis of the Minto Inlet Formation and Kilian Formation, of the Shaler Supergroup, Northwest Territories
}

by

\author{
John K. G. Prince
}

A thesis submitted to the Faculty of Graduate and Postdoctoral Affairs in partial fulfillment of the requirements for the degree of

\author{
Master of Science
}

in

Earth Sciences

Carleton University

Ottawa, Ontario

(C) 2014

John Prince 


\section{Abstract:}

The Minto Inlet Formation ( $<891 \mathrm{Ma} ;>762 \mathrm{Ma}$ ) is a $300 \mathrm{~m}$ thick unit of predominantly claystone, siltstone, carbonate rock and sulphate evaporite rock. Three informal, regionally extensive members are defined: the lower evaporite, carbonate and upper evaporite members. The Kilian Formation ( $<795 \mathrm{Ma} ;>723 \mathrm{Ma}$ ) is a $>500 \mathrm{~m}$ thick succession that is compositionally similar to the Minto Inlet Formation, and is here subdivided into 4 third-order depositional sequences and their respective systems tracts. Both formations reflect deposition on a subtidal to supratidal ramp, influenced by siliciclastic supply, arid climate and tectono-eustasy.

Sulphate samples from the Minto Inlet Formation are characterized by low average $\delta^{34} S(\sim 17 \%$ ) with little secular variability $(\sigma=1.36 \%$ o, $n=67)$, whereas samples from the Kilian Formation show high average $\delta^{34} S$ ( 26\%) and high secular variability $(\sigma=8.63 \%, n=67)$. Biogeochemical models indicate that a temporary reorganization of the sulphur flux out of the ocean, characterized by an initial decrease in the pyrite burial fraction $\left(f_{p}\right)$ from $\sim 1$ to $\sim 0.3$, was initiated prior to the deposition of the Minto Inlet Formation, and a return of $f_{p}$ values near 1 (recorded in the Kilian Formation), is inferred to have occurred during deposition of the intervening Wynniatt Formation. These changes are interpreted to be the result of widespread and thick (basin-scale) evaporite deposition during the middle Neoproterozoic, possibly driven by the migration of Rodinia and the multiple intracratonic basins which it hosted across low latitude arid climate belts. 


\section{Acknowledgements:}

I would like to thank my supervisors Rob Rainbird and George Dix for allowing me to attempt a project of this scale. Thanks to Rob for initially taking me on to the Victoria Island project, his patience and his faith in me and my work have been infinite. Thank you to Boz Wing for all his multiple, multiple sulphur isotope consultations and allowing me to use lab space at McGill for the very messy and long process of carbonate associated sulphate. I would like to thank Jean Bedard for putting me up in his home both before and after my first field season and for all of the "safety meetings" while in the field. Thank you to Etienne Girard for taking time to introduce me to Arc GIS and for sacrificing the bones of his ankle for our field internet connection. Thank you to Sharon, Rosanda and Susie for the gourmet all-you-can-eat meals every night in the field. Gilly, Durbano, Ben, Chuck, Adam, Nicole, Jeff, Kat, Jordan, Danielle, Trent and Charlie are all gratefully acknowledged for their partial insanity, safety meeting contributions and union support. Special thanks to Gilly for making sure that I made my flight out of Yellowknife when I was in no state to be concerned with such things. Our Helicopter Pilots; Gary, Kyle, Greg and Darcy must be thanked for their efforts in getting every one of us back to camp every night, even if it meant flying through fog to find us. The local camp staff and wildlife monitors; Noah, Bryan, Jack and Derek are gratefully acknowledged for their expert advice and anecdotes. Special thanks to Isaac for his advice and wisdom on the lay of the land. Thank you to Bryan Krapez for never-ending entertainment. Thank you to my examiners, Don Cummings and Keiko Hattori, for their constructive comments and suggestions. Thanks to Andre Pellerin, Thi Hao Bui for their helpful discussions on laboratory protocol. Thank you to my family for their financial and emotional support through my career as a student. Finally thank you to Suzie, for the patience, encouragement and steady supply of lunches through thick and thin. 


\section{Table of Contents:}

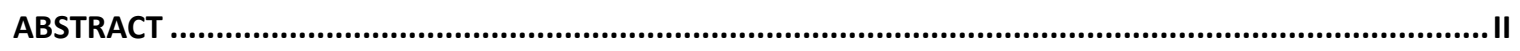

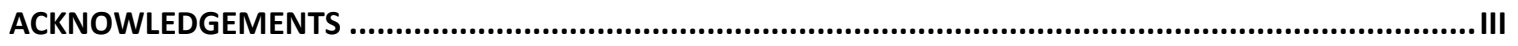

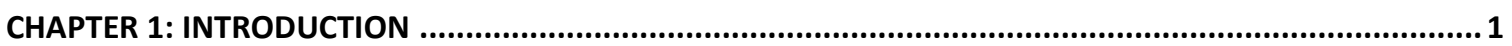

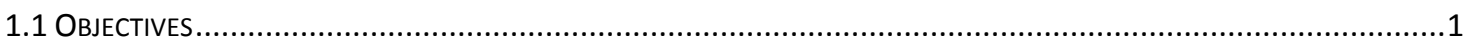

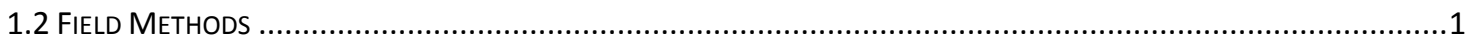

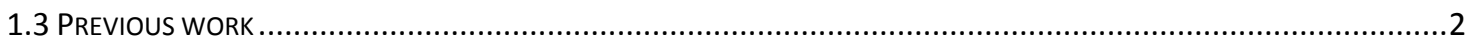

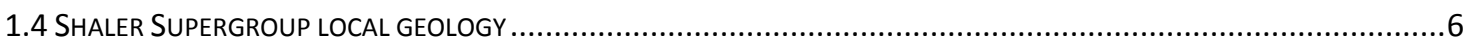

\section{CHAPTER 2: LITHOSTRATIGRAPHY AND SEQUENCE STRATIGRAPHY OF EVAPORITIC UNITS IN THE}

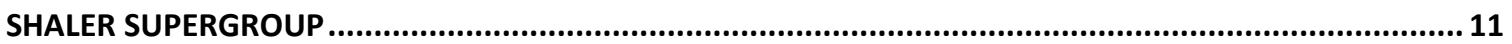

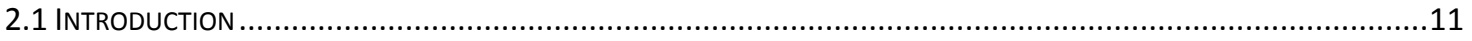

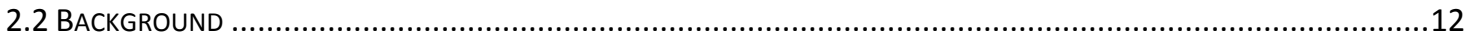

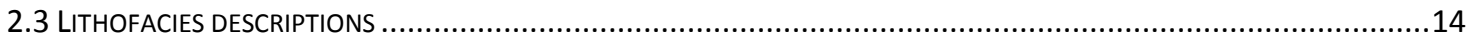

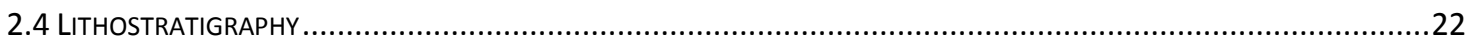

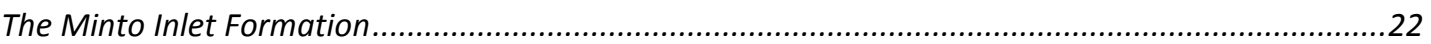

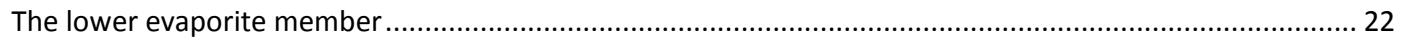

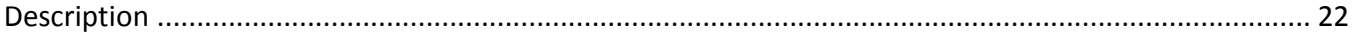

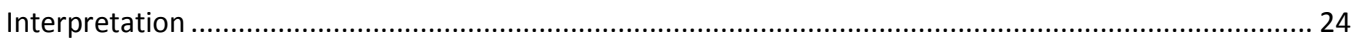

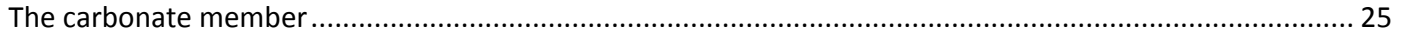

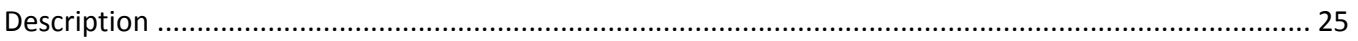

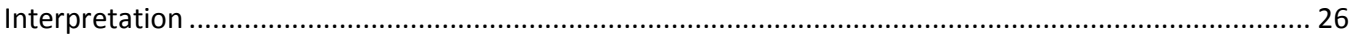

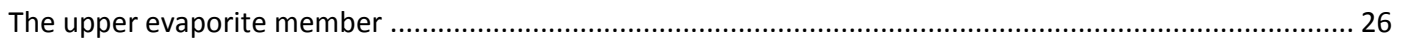

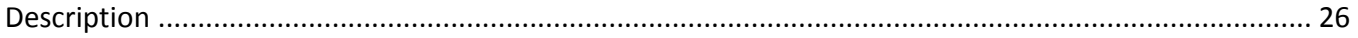

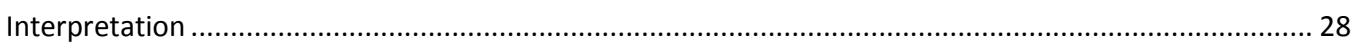

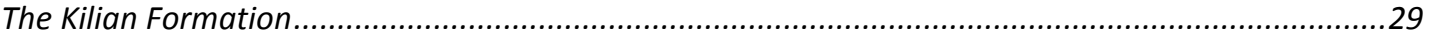

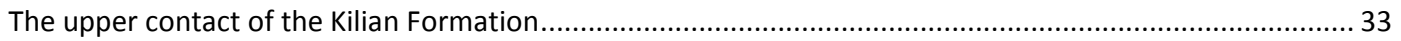

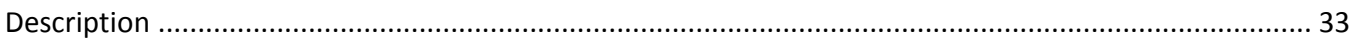

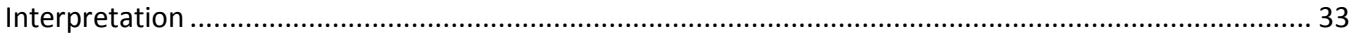




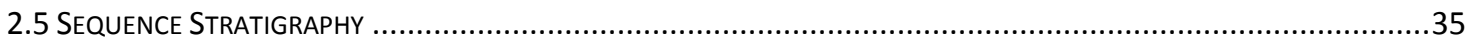

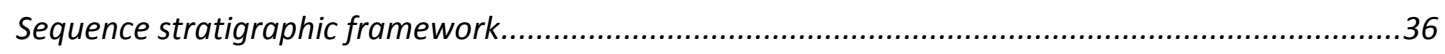

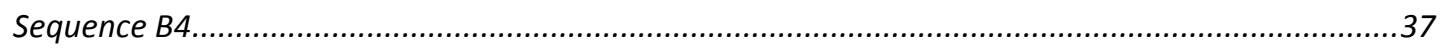

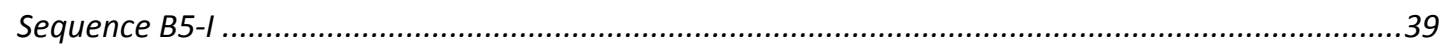

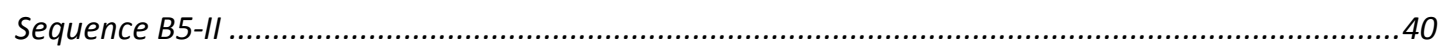

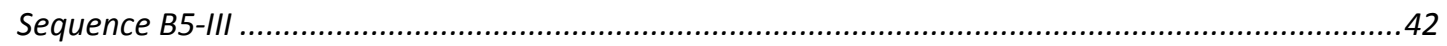

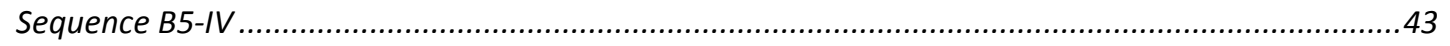

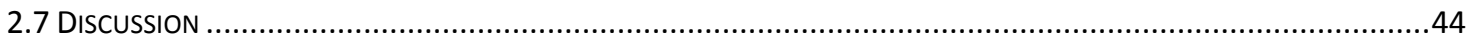

Sequence stratigraphic evolution of the Minto Inlet Formation ................................................44

Sequence stratigraphic evolution of the Kilian Formation ....................................................4

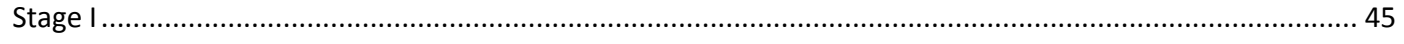

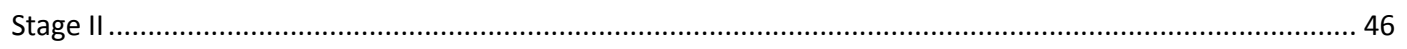

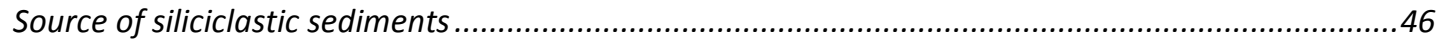

\section{CHAPTER 3: THE BIOGEOCHEMICAL CYCLING OF SULPHUR AND CARBON DURING THE LOWER TO}

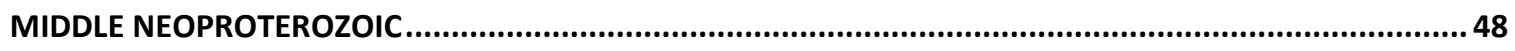

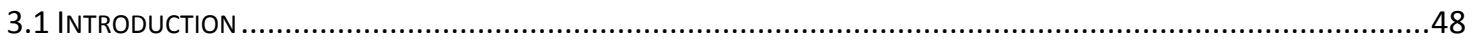

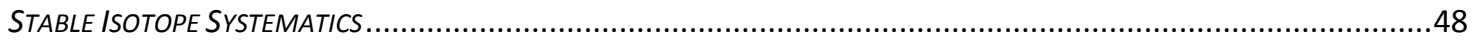

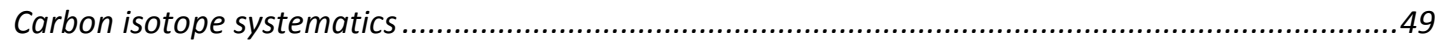

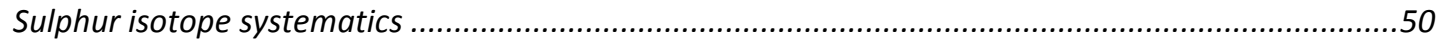

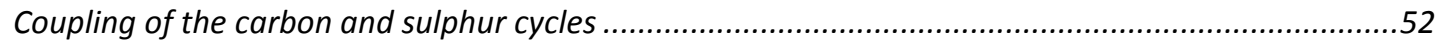

3.2 CURRENT UNDERSTANDING OF THE NEOPROTEROZOIC CYCLES OF CARBON AND SULPHUR.................................54

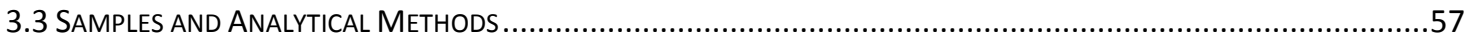

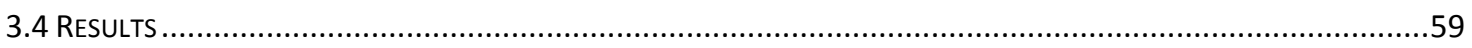

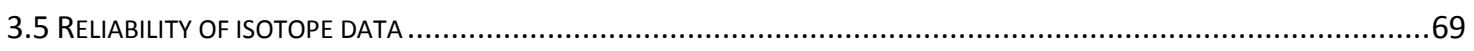

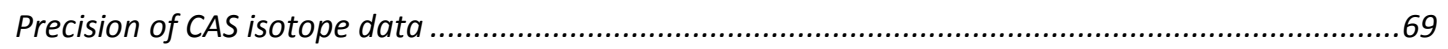

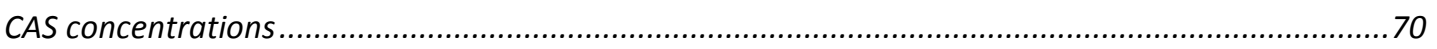

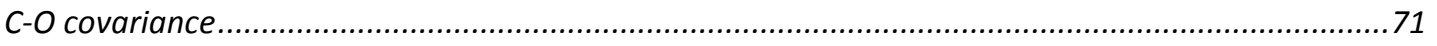




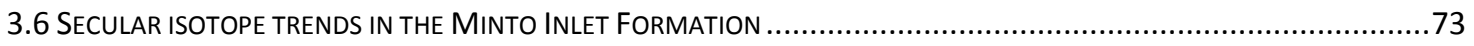

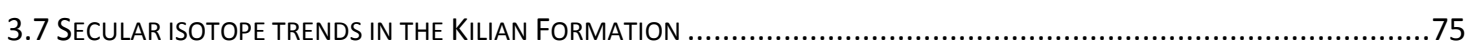

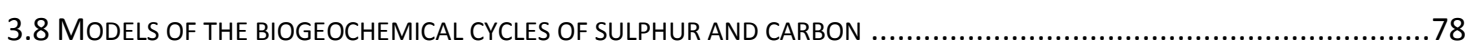

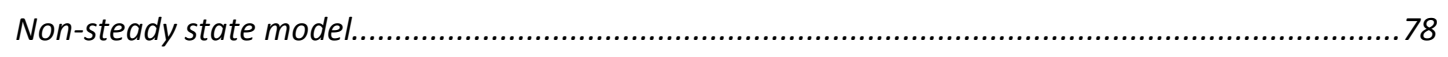

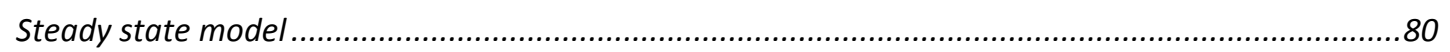

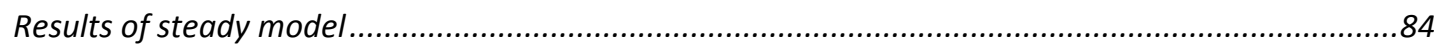

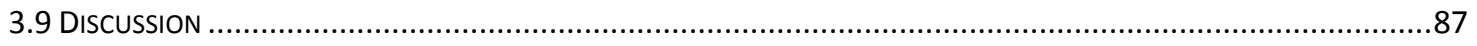

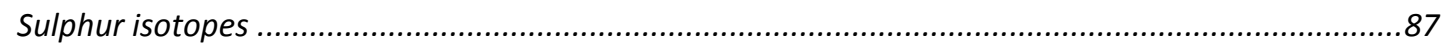

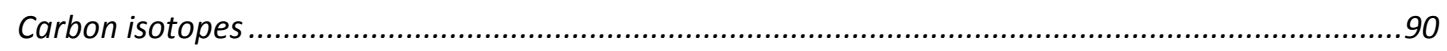

Implied changes to the biogeochemical cycling of Sulphur and Carbon........................................90

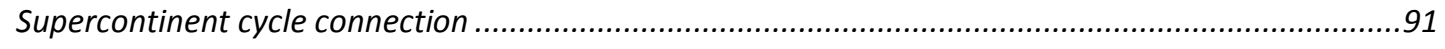

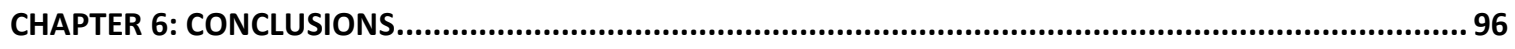

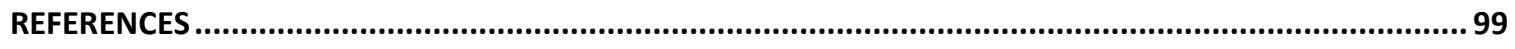

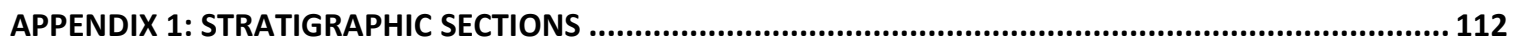

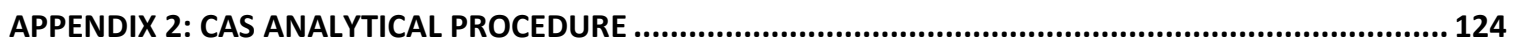




\section{LIST OF FIGURES}

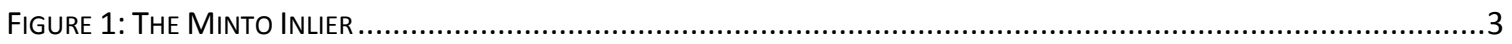

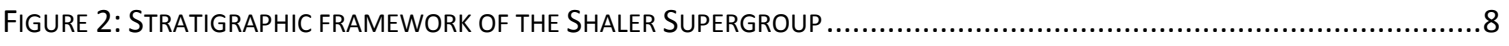

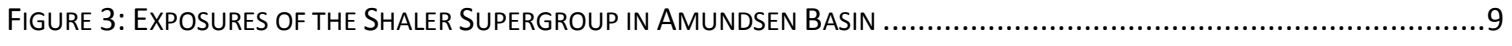

FIGURE 4: EXPOSURES OF THE SHALER SUPERGROUP ON THE SOUTH SHORE OF MINTO INLET ...................................10

FIGURE 5: FIELD SITE LOCATIONS OF STRATIGRAPHIC SECTIONS AND IMPORTANT STATIONS .....................................14

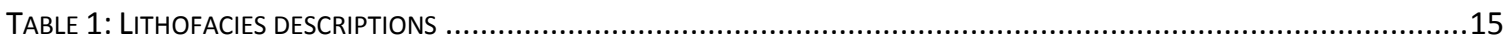

FIGURE 6: BLOCK DIAGRAM OF DEPOSITIONAL ENVIRONMENTS THROUGH THE KILIAN FORMATION.................................17

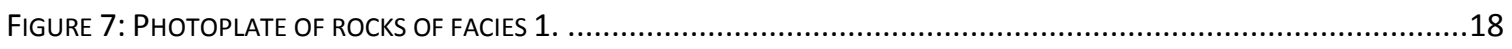

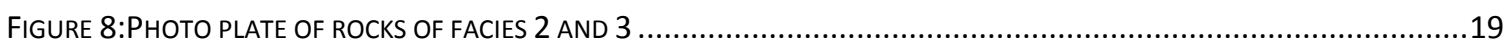

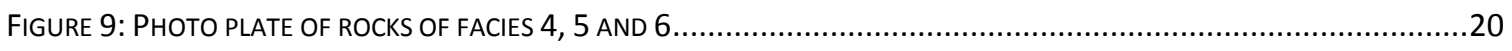

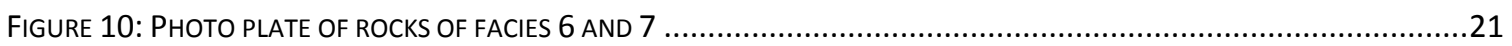

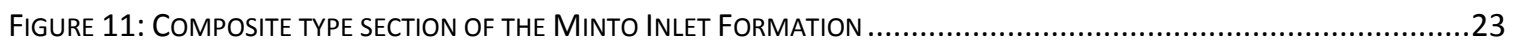

FiguRE 12: PHOTO PLATE OF EXPOSURES OF THE UPPER EVAPORITE MEMBER OF THE MINTO INLET FORMATION .................27

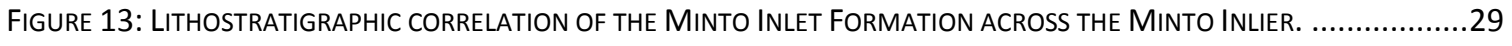

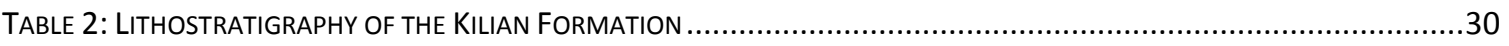

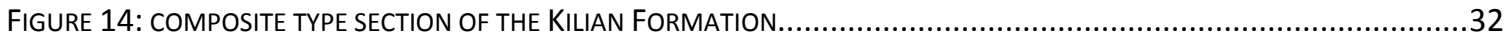

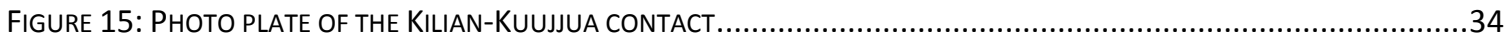

FIGURE 16: RELATIVE SEA LEVEL CURVE WITH RELEVENCE TO SYSTEMS TRACTS................................................36

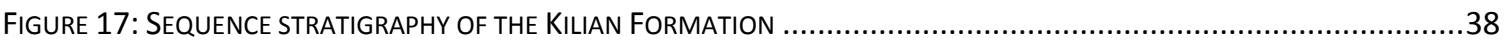

FIGURE 18: PHOTO PLATE OF IMPORTANT SEQUENCE STRATIGRAPHIC SURFACES. .................................................4 41

FIGURE 19: SIMPLE SULPHUR ISOTOPE SCHEMATIC FOR A CLOSED SYSTEM IN STEADY STATE.........................................51

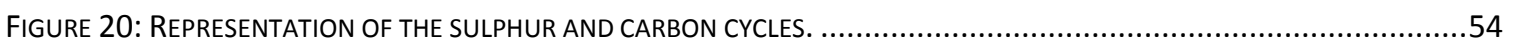

FIGURE 21: STABLE ISOTOPE RECORD OF ${ }^{13}$ C THROUGH THE NEOPROTEROZOIC .....................................................55 
TABLE 3: MULTIPLE SULPHUR ISOTOPE COMPOSITION OF Minto INLET FORMATION SAMPLES

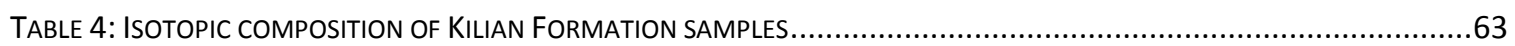

TABLE 5: KILIAN FORMATION CAS CONCENTRATION AND MULTIPLE SULPHUR ISOTOPIC COMPOSITION ............................67

FIGURE 22: SULPHUR ISOTOPE DATA FROM THE MINTO INLET AND KILIAN FORMATIONS...........................................

FIGURE 23: CAS CONCENTRATION VS CAS SULPHUR ISOTOPE COMPOSITION OF KILIAN FORMATION SAMPLES .....................71

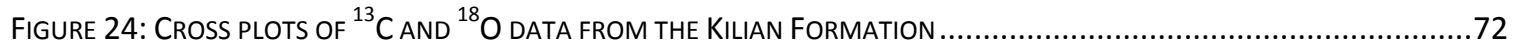

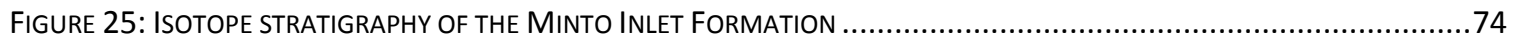

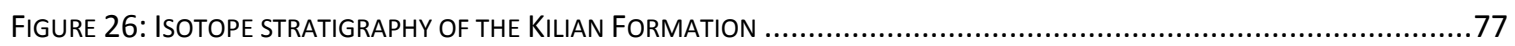

FIGURE 27: ISOTOPIC SENSITIVITY OF THE DIC AND SEAWATER SULPHATE RESERVOIRS AS A FUNCTION OF RESERVOIR SIZE......79

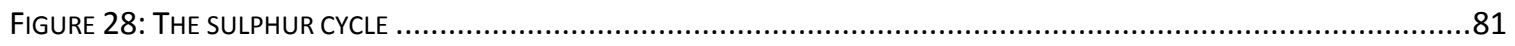

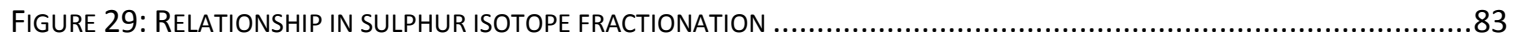

FIgURE 30: PYRITE BURIAL fRACTION OF Minto INLET AND KILIAN FORMATION SAMPLES ........................................84

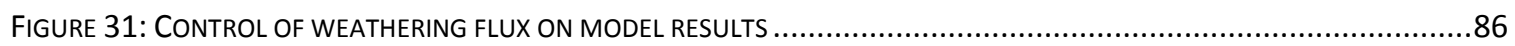

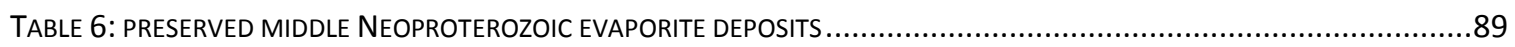

FIGURE 32: SUPER CONTINENT CYCLE AND ITS CONNECTION WITH BASIN-SCALE EVAPORITE DEPOSITION ..........................93

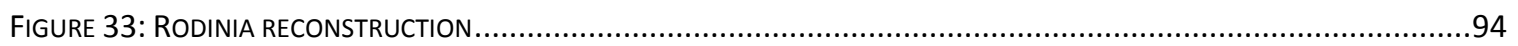

FIGURE 34: SEAWATER CHEMISTRY AND THE SUPERCONTINENT CYCLE .........................................................95 


\section{Chapter 1: Introduction}

\subsection{Objectives:}

The objectives of this study are

1) to employ lithostratigraphic and sequence stratigraphic frameworks to deduce environmental conditions in the Amundsen Basin during deposition of the Minto Inlet and Kilian formations of the upper Shaler Supergroup, 910Ma - 723Ma;

2) to measure and interpret the stable isotope geochemistry of the Minto Inlet and Kilian formations using models of the biogeochemical cycles of carbon and sulfur; and

3) to link lithostratigraphic, sequence stratigraphic and chemostratigraphic data to better interpret the geological evolution of the Amundsen Basin, and the biogeochemical cycles of carbon and sulphur during deposition of the Minto Inlet and Kilian formations.

\subsection{Field Methods}

This work relies on interpretations and field observations made by the author during the summer field seasons of 2010 and 2011 and was made possible by the Geological Survey of Canada (Geomapping for Energy and Minerals Program, Victoria Island project). The field area is within the Minto Inlier, located in the western Canadian Arctic on Victoria Island (Figure 1). Personnel, gear and supplies were transported to 
Ulukhaktok by barge or by commercial flight and subsequently flown into base camp by Twin Otter (DHC6) with service provided by Kenn Borek Air Ltd. During the field season personnel were transported from base camp to their respective field sites by two Bell 206L Helicopters provided by Trinity Helicopters Ltd. (now Summit Helicopters) and Helicopter Transport Company (HTC). Field observations and samples were collected from a total of 3 stratigraphic sections and 1 drill core through the Minto Inlet Formation and 6 stratigraphic sections through the Kilian Formation in the Southwest Domain of the Minto Inlier (Figure 1). Each of these sections was measured using a graduated staff with the aid of field assistants. Samples of fresh rock were collected at 3 $m$ intervals for stable isotope analysis of sulphur carbon and oxygen. Sampling targets were sulphate evaporites for the measurement of multiple sulphur isotopes and carbonate rocks for measurement of stable inorganic carbon and oxygen. Only a few intervals within the Kilian Formation are rich in sulphate minerals, so in the absence of gypsum and/or anhydrite phases limestone or dolostone samples were collected for the measurement of carbonate-associated sulphate (CAS).

\subsection{Previous work}

Early investigations of the geology of Victoria Island are included in the reports of O'Neill (1924) and Washburn (1947) after their respective scientific expeditions to the Arctic. A much more extensive investigation of the geology of Victoria Island was carried out by Thorsteinsson and Tozer (1962) during a 1959 expedition to Victoria, Banks and Stevenson islands. The authors, along with R.L. Christie and J.G. Fyles and two light- 
weight Piper Cub (PA-18) aircraft outfitted with Phipps tundra tires, quite accurately mapped the Minto Inlier at a 1:1,000,000 scale. In their report, Thorsteinsson and Tozer (1962) described the early and late Precambrian, Paleozoic, Mesozoic and Cenozoic geology of the three Arctic islands. The late Precambrian succession was named the Shaler Group and subdivided into 5 formations. In stratigraphic order those were Glenelg, Reynolds Point, Minto Inlet, Wynniatt and Kilian formations. This was the stratigraphic framework upon which all subsequent work in the area has been built.

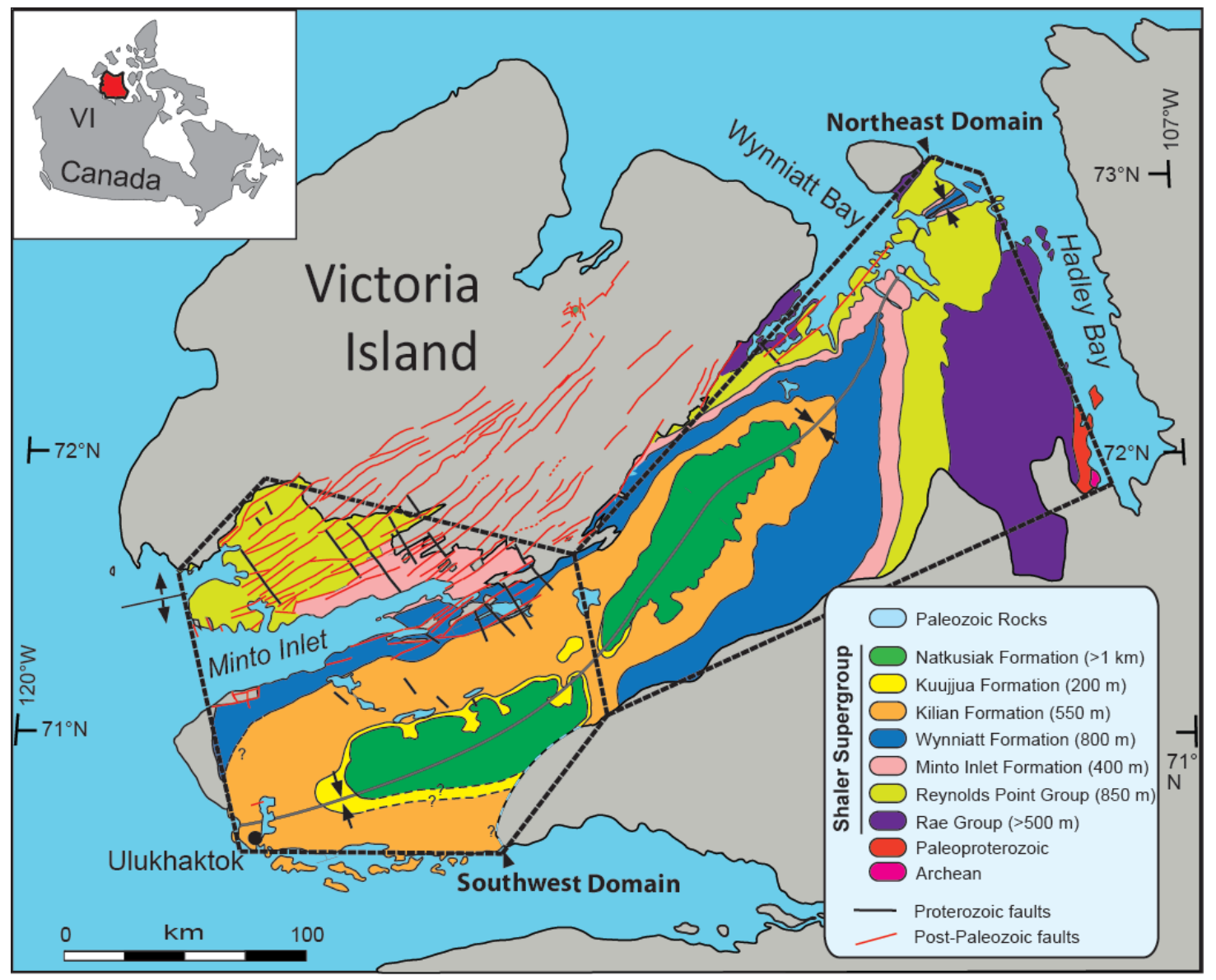

Figure 1: The Minto Inlier after Thorsteinsson and Tozer (1962) Rainbird (1991) and Bedard et al. (2012). For descriptive purposes it is divided into Northeast and Southwest Domains. 
In the 1970s, detailed work was conducted on the individual formations of the lower Shaler Group (see Young, 1974; Young and Jefferson, 1975; Young and Long, 1976; Young and Long, 1977a; Young and Long 1977b; Young et al., 1979). Among the many scientific contributions included in these works was the interpretation of a NE-SW paleo-shoreface orientation (present compass points), with the basin open to the northwest (Young, 1974; Young and Jefferson, 1975), as well as the subdivision of the strata in the Proterozoic sedimentary basins of northwestern Laurentia into three unconformitybound sequences, A, B and C (Young et al., 1979). This work included lithologic interpretations and important correlations between individual formations of the Shaler Group and the Mackenzie Mountains Supergroup.

In the 1980s, the first detailed descriptions of the formations of the upper Shaler Group including the Kilian, Kuujjua and Natkusiak formations were published (see Jefferson, 1985; Jefferson et al., 1985), including definition of the Kuujjua Formation (Jefferson, 1985), previously considered a member of the upper Kilian Formation. Young (1981) offered comprehensive descriptions and interpretations of the Shaler Supergroup along with definition of the Amundsen Embayment, now referred to as the Amundsen Basin, where deposition of the Shaler Supergroup occurred.

The first chemostratigraphic study of the Shaler Group was published by Asmerom et al. (1991). In total 17 samples through the Reynolds Point, Minto Inlet and Wynniatt formations were analyzed for ${ }^{87} \mathrm{Sr} /{ }^{86} \mathrm{Sr}, \delta^{13} \mathrm{C}_{\mathrm{carb}}$ and $\delta^{18} \mathrm{O}$. Although significant variability was observed in the $\delta^{13} \mathrm{C}$ values, the strontium isotopes were the primary 
focus of the paper. Heaman et al. (1992) dated the sills and dykes which intrude the Shaler Supergroup at $723+4 /-2 \mathrm{Ma}(\mathrm{U}-\mathrm{Pb})$ which provided a lower age limit for the deposition. Detailed sedimentological studies of the Kilian and Kuujjua formations are offered in Rainbird (1991), Rainbird (1992) and Rainbird (1993) which are focussed on the lithostratigraphy, fluvial architecture and evidence for mantle plume derived uplift, respectively. A proposed reorganization of the stratigraphy of the Shaler Group was published by Rainbird et al. (1994), who elevated the lower two formations to groups and the Shaler Group to Supergroup status. The name Glenelg was abandoned for the Rae Group, which was subdivided into the Escape Rapids, Mikkelsen Islands, Nelson Head and Aok formations. The Reynolds Point Group was subdivided into the Grassy Bay, Boot Inlet and Jago Bay formations (Figure 2). An expansion of the sequence stratigraphic framework of Young (1979), including detailed correlations, between the rocks of the Ogilvie, Wernecke and Mackenzie Mountains and those of Amundsen Basin was proposed by Rainbird et al. (1996). These authors also proposed correlations with rocks of similar age in the Centralian Superbasin of central Australia.

More recently Long et al. (2008) further subdivided sequence B of Young et al. (1979) and Rainbird et al. (1996) into 5 second-order sequences (sequences B1- B5). Jones et al. (2010) published a high resolution $\delta^{13} C_{\text {carb }}$ curve spanning much of the Shaler Supergroup including the Aok, Boot Inlet, Wynniatt and Kilian formations. The authors proposed an alternative correlation between the Shaler Supergroup and the Mackenzie Mountains Supergroup, based upon chemostratigraphy rather than 
lithostratigraphic similarities, upon which previous correlation schemes had been constructed.

\subsection{Shaler Supergroup local geology}

The Shaler Supergroup is a greater than $4 \mathrm{~km}$ thick succession of siltstone, sandstone, carbonate and evaporite rocks, deposited within an intra-cratonic basin or embayment near the north-western margin of Laurentia (Young, 1981; Rainbird et al., 1994; Rainbird et al., 1996). Paleomagnetic constraints place the Laurentian craton at equatorial latitudes for much of the Neoproterozoic (Heaman et al., 1992; Kirschvink, 1992; Park, 1994; Li et al., 2008), including the depositional window of the Shaler Supergroup, $\leq 1151 \mathrm{Ma}$ (U/Pb detrital zircons) (Rayner and Rainbird, 2013) to $\geq 723+4 /-2$ Ma (U/Pb baddeleyite) (Heaman et al., 1992). The Shaler Supergroup unconformably overlies rocks of the Paleoproterozoic Goulburn Supergroup on Victoria Island (Campbell, 1985; Rainbird et al., 1996), which in turn overlie Archean granodiorites (Thorsteinsson and Tozer, 1962). The entire Precambrian succession is unconformably overlain by flat lying Cambro-Ordovician sandstone and carbonate rocks (Thorsteinsson and Tozer, 1962).

Rocks of the Shaler Supergroup are best exposed in the Minto Inlier on Victoria Island, NWT, but have been documented in the Cape Lambton, Brock and Duke of York inliers as well as in the Coppermine region (Cook and Aitken, 1969; Figure 3; Baragar and Donaldson, 1973; Young, 1981; Rainbird et al., 1994). The Shaler Supergroup is subdivided into 13 formations (Figure 2), in ascending order they are: Escape Rapids, 
Mikkelsen Island, Nelson Head, Aok, Grassy Bay, Boot Inlet, Fort Collinson, Jago Bay, Minto Inlet, Wynniatt, Kilian, Kuujjua and Natkusiak formations. Strata of the Shaler Supergroup are intruded by more than $20,1-50 \mathrm{~m}$ thick gabbroic sills and dykes of the $723+4 /$-2 Ma Franklin large igneous province (LIP) (Heaman et al., 1992; Macdonald et al., 2010). The sills and dykes are considered to be the plumbing or feeder system for the Natkusiak Formation flood basalts which cap the sedimentary units (Baragar, 1976; Jefferson et al., 1985).

The outcrop belt, referred to as Minto Inlier (Fortier et al., 1954), trends roughly NE-SW across the north-western portion of Victoria Island. The rocks dip shallowly ( 5$\left.10^{\circ}\right)$, their attitude structurally controlled by the Holman Island syncline on the south and the Walker Bay anticline on the north of Minto Inlet (Figure 2). There are two sets of sub vertical faults and fractures that cut the Shaler Supergroup: a roughly north-west set, which only cuts Proterozoic strata and typically has limited offset, and a roughly northeast set, which is parallel to fold axes, and has significant offset (up to $200 \mathrm{~m}$ ) that affects both Paleozoic and Proterozoic rocks. 


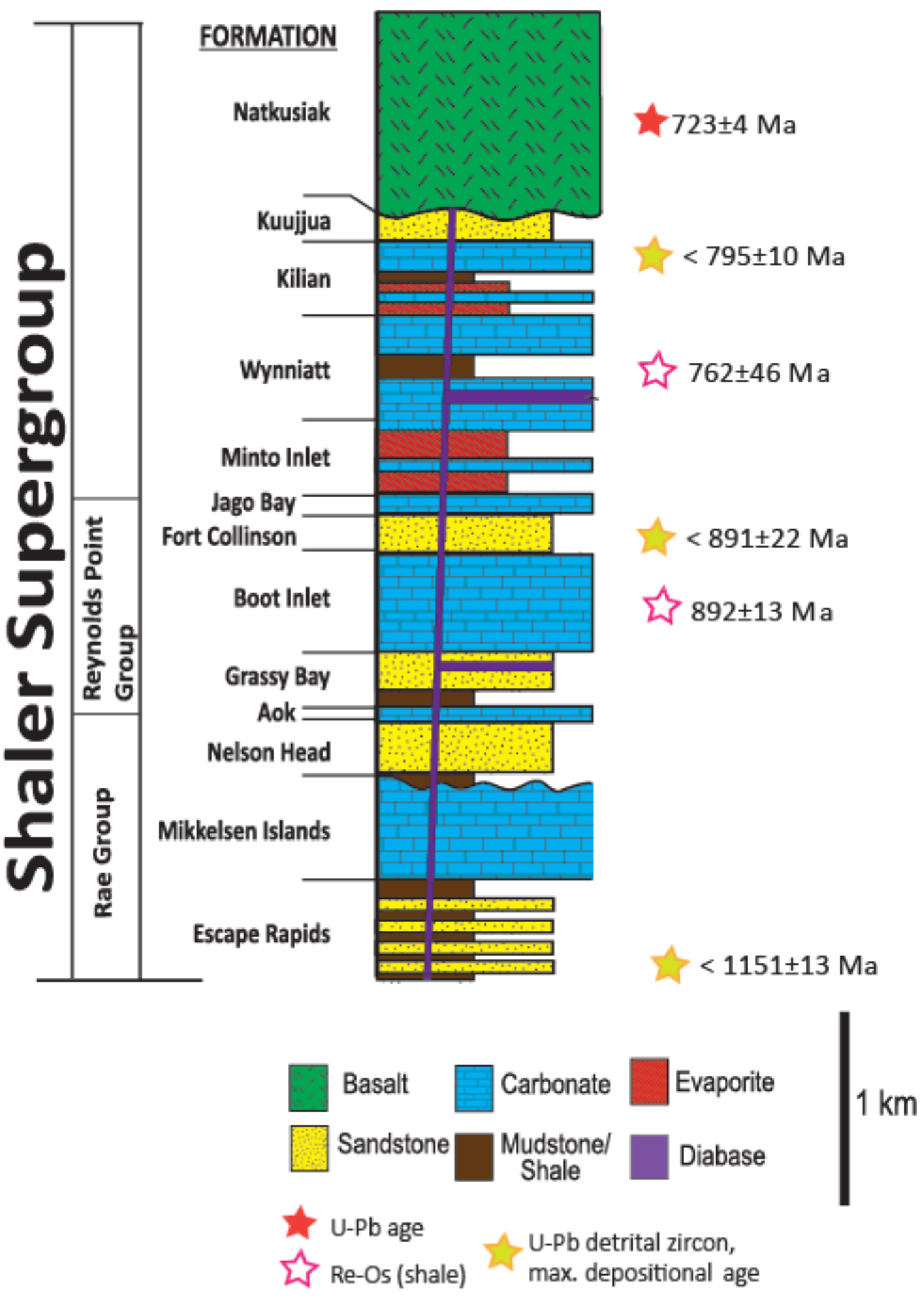

Figure 2: Stratigraphic framework of the Shaler Supergroup after Rainbird et al. (1994). Age constraints from Heaman et al. (1992), Rayner and Rainbird (2013) and van Acken et al. (2012). 


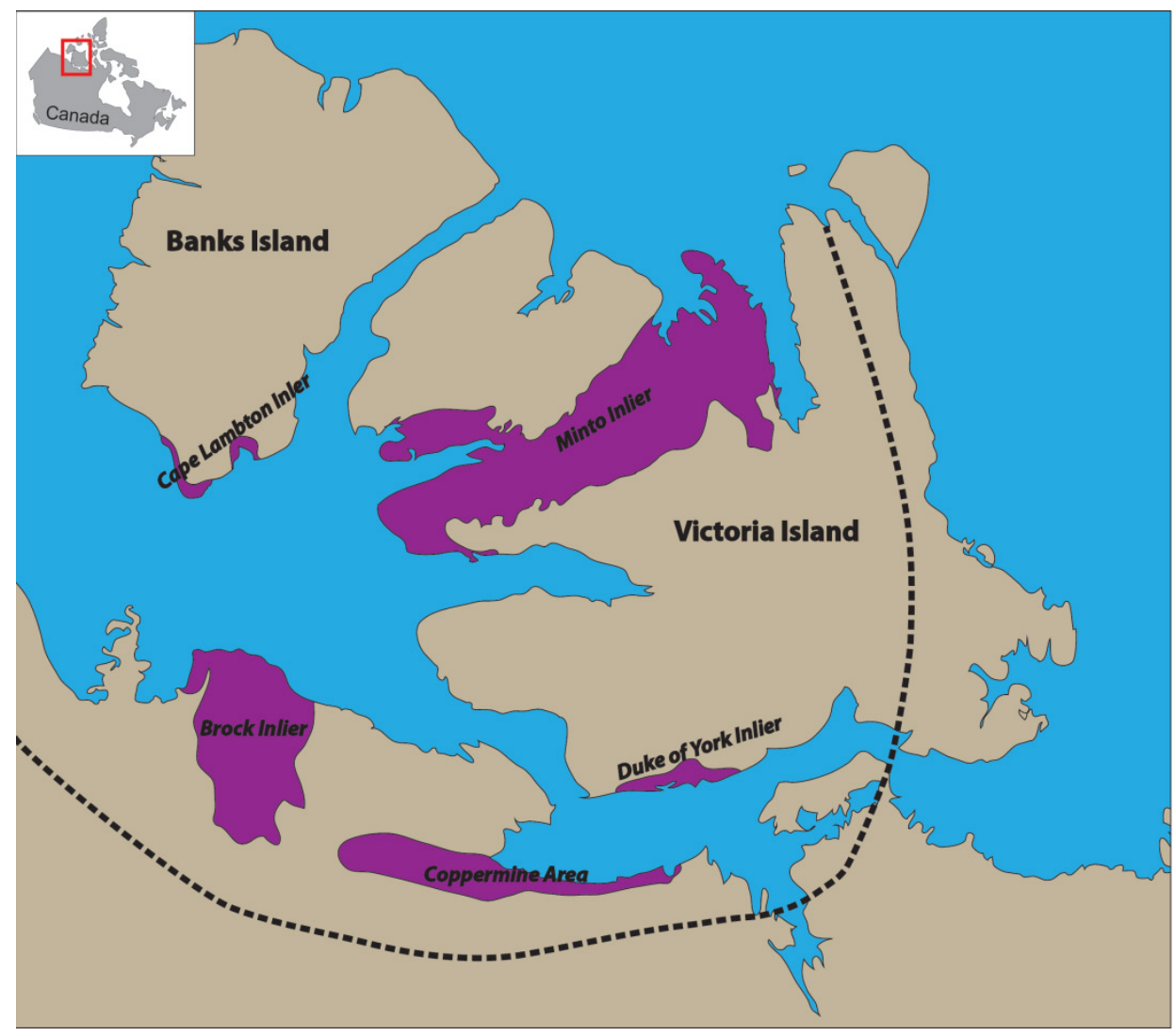

Figure 3: Exposures of the Shaler Supergroup in Amundsen Basin. Inferred zero-edge of the basin (dotted line) during the deposition of the Shaler Supergroup, after Rainbird et al. (1996).

The best exposures of the sedimentary rocks on Victoria Island occur beneath larger diabase sills, which are more resistant to weathering and erosion than the sedimentary rocks. The Shaler Supergroup is thus preserved in a stepwise series of cliffs and plateaus (cuestas), each separated by shallowly dipping planes (Figure 4). 


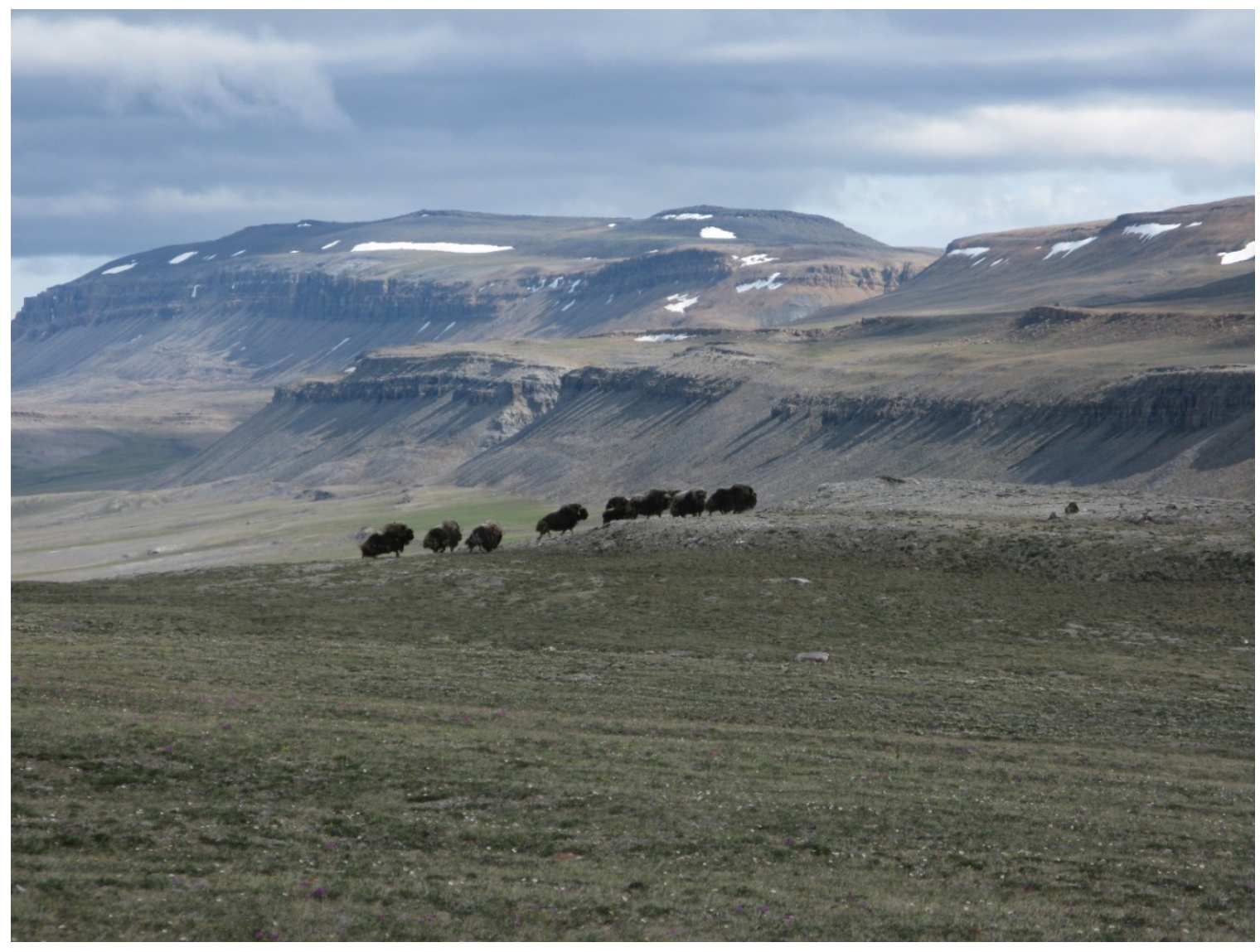

Figure 4: Exposures of the Shaler Supergroup on the south shore of Minto Inlet. 


\section{Chapter 2: Lithostratigraphy and sequence stratigraphy of evaporitic units in the}

\section{Shaler Supergroup}

\subsection{Introduction}

The Minto Inlet and Kilian formations host the only significant evaporite deposits within the Shaler Supergroup and represent rare examples of widespread and thick (basin-scale) Precambrian evaporites. Basin-scale evaporite deposits record the confluence of appropriate tectonic and climatic regimes (Warren, 2010). Evaporite deposits are rare in Precambrian strata worldwide, partly because of unfavourable seawater chemistry for the formation of evaporite minerals (eg. low seawater sulphate concentrations; Kah et al., 2004), but also because of the low preservation potential of the highly soluble minerals that make up evaporite deposits. The middle Neoproterozoic ( 850-750 Ma) evaporite deposits in the Shaler Supergroup, are an exception because they are well preserved, and, together with correlatives in the northern Canadian Cordillera, Central Australia and Central Africa represent large-scale evaporite deposition in multiple basins (e.g. Behr et al., 1983; Lindsay, 1987; Preiss, 2000; Jackson et al., 2003; Grey, 2005; Turner, 2009). While there are numerous reports on the geology of both the Minto Inlet Formation and the Kilian Formation, there has so far been no formal descriptions of the of the Minto Inlet Formation from the Southwest Domain of the Minto Inlier. Detailed sequence stratigraphic analysis of the Kilian Formation has not been previously attempted, although transgressive-regressive cycles were identified by Rainbird (1991; 1993). 
The purpose of this chapter is to divide the Minto Inlet Formation and Kilian Formation into recognizable lithofacies, which can then be used to define informal members using lithofacies associations. This is especially important in the case of the Minto Inlet Formation, as laterally consistent members have not so far been proposed for this formation. The members of the Kilian Formation, previously proposed by Rainbird (1991), are here reinterpreted using the principles of facies modelling. Lithostratigraphic, facies and sequence stratigraphic analyses conducted in this work will be used to help deduce environmental conditions in the Amundsen Basin during deposition of the Minto Inlet and Kilian formations.

\subsection{Background}

Formal definition and description of the Minto Inlet and Kilian formations by Thorsteinsson and Tozer (1962) included definition of a general type area of the Minto Inlet Formation at the head of Minto Inlet in the Southwest Domain of Minto Inlier (Figure 1). Their observations of the Kilian Formation were confined to the Northeast Domain where they subdivided the Kilian Formation into two members: a gypsumbearing lower member and a gypsum-free upper member. Further description and interpretation of both formations was given by Young (1981), who studied exposures in in the Wynniatt Bay area of the Northeast Domain (Figure 1). Young (1981) measured a total thickness of $\sim 300 \mathrm{~m}$ for the Minto Inlet Formation and subdivided it into two informal members, a lower member, characterized by coarsely bedded dolostone and gypsum with minor chert nodules, and an upper member, characterized by thinly 
bedded and cyclic gypsum and dolostone. Young measured a total thickness of $400 \mathrm{~m}$ for the Kilian Formation in the Northeast Domain and used the same two-member subdivision as Thorsteinsson and Tozer (1962). Phaneuf (1993), also working on exposures in the Northeast Domain, further subdivided the Minto Inlet Formation into 5 informal members: the lower evaporite, lower carbonate, middle evaporite, upper carbonate and upper evaporite. Descriptions of the Kilian Formation from the Southwest Domain were carried out by Jefferson (1985) who subdivided the upper Kilian Formation into four informal members: the red and tan carbonate, grey evaporite carbonate, cream limestone and red clastic members. Rainbird (1991) further subdivided the Kilian Formation into 8 informal members based on detailed lithostratigraphic analysis of stratigraphic sections from both the Southwest and Northeast domains of Minto Inlier. Those members are, in stratigraphic order, the lower evaporite, lower cyclic carbonate, middle evaporite, upper cyclic carbonate, clasticcarbonate, tan carbonate, upper evaporite and red shaly carbonate.

Observations presented in this chapter come from 7 stratigraphic sections and one drill core from the Southwest Domain as well as a single stratigraphic section in the Northeast Domain of Minto Inlier (see Appendix 1, Figure 5). No complete sections through the Minto Inlet Formation or Kilian Formation are known in the Southwest Domain, so the type sections presented here (Figures 6 and 8 ) are composite sections constructed from the correlation of individual stratigraphic sections (see Appendix 1). Correlation of individual sections was facilitated by limited deformation and well understood structural controls on sedimentary outcrops (see Chapter 1). 


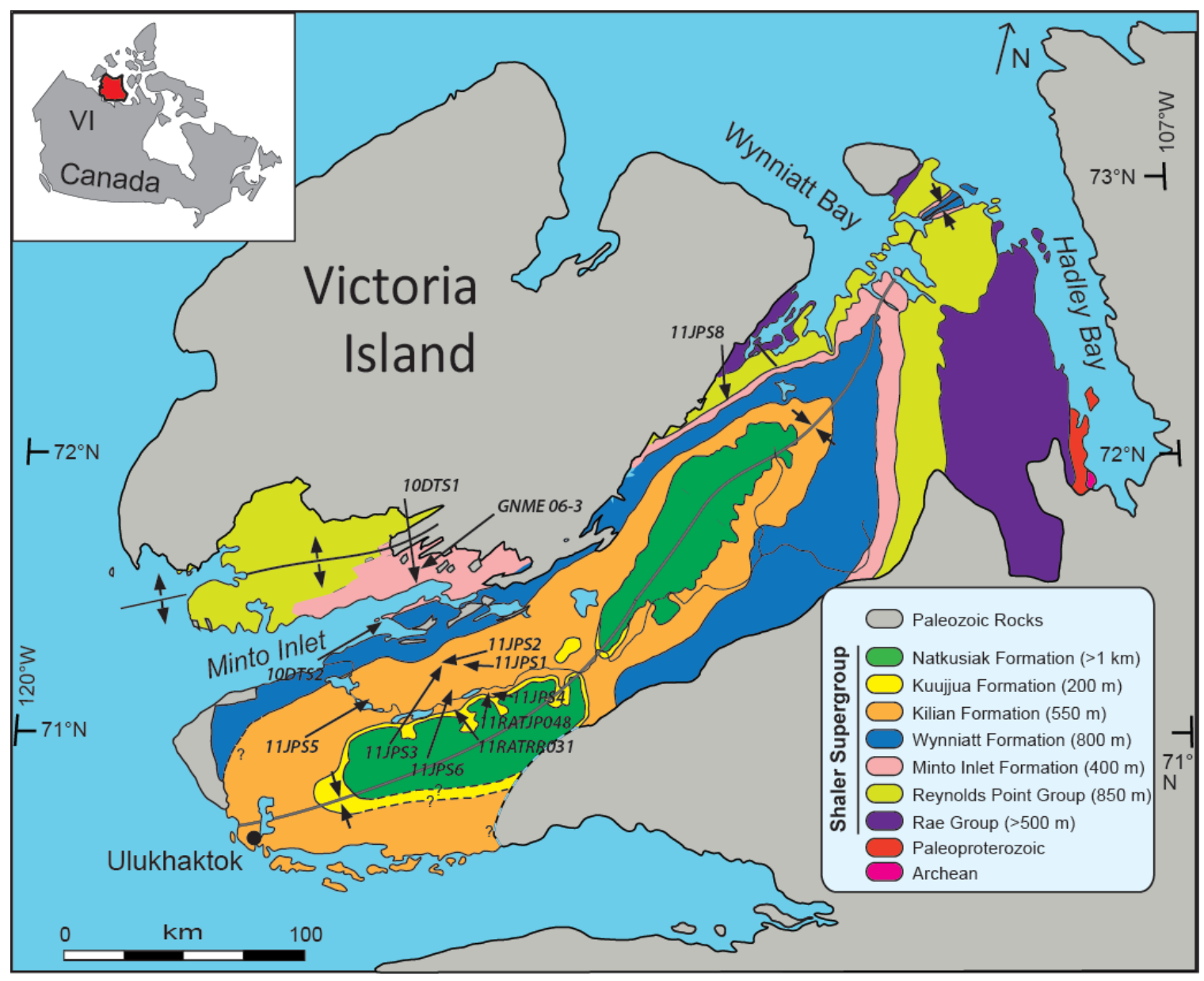

Figure 5: Field locations of stratigraphic sections (10DTS1, 10DTS2, 11JPS1, 11JPS2, 11JPS3, 11JPS4, 11JPS5, 11JPS6, 11JPS8), drill site (GNME 06-3) and important stations (11RATJP048, 11RATRR031) discussed in text. See Appendix 1 for GPS coordinates.

\subsection{Lithofacies descriptions}


Table 1: Lithofacies descriptions

\begin{tabular}{|c|c|c|c|c|c|}
\hline Lithofacies & Lithology & Bedding & Structures & $\begin{array}{l}\text { Depositional } \\
\text { environment } \\
\text { (see Figure 6) } \\
\end{array}$ & Photos \\
\hline $1-1$ & $\begin{array}{l}\text { Friable gypsiferous siltstone/claystone; } \\
\text { nodular white to pink gypsum/anhydrite, } \\
\text { dolomitic wackestone to grainstone; lenticular } \\
\text { medium and fine-grained quartz arenite }\end{array}$ & $\begin{array}{l}\text { Laminated, medium } \\
\text { bedded or massive }\end{array}$ & $\begin{array}{l}\text { Satinspar veins, } \\
\text { desiccation cracks, } \\
\text { de-watering } \\
\text { structures, chicken- } \\
\text { wire texture, rip-up } \\
\text { clasts }\end{array}$ & $\begin{array}{l}\text { Sabkha, supratidal/ } \\
\text { intertidal evaporitic } \\
\text { mudflat }\end{array}$ & $\begin{array}{l}\text { Figure } \\
7 A, B\end{array}$ \\
\hline $1-11$ & $\begin{array}{l}\text { Clastic gypsum/anhydrite (gypsarenite); } \\
\text { grainstone and dolomitic grainstone }\end{array}$ & $\begin{array}{l}\text { Thinly to thickly } \\
\text { bedded, rarely cross- } \\
\text { stratified }\end{array}$ & $\begin{array}{l}\text { Gypsum } \\
\text { pseudomorphs }\end{array}$ & $\begin{array}{l}\text { Saltern, intertidal to } \\
\text { subtidal, restricted }\end{array}$ & $\begin{array}{l}\text { Figure } \\
7 C, D, F\end{array}$ \\
\hline $1-I I I$ & $\begin{array}{l}\text { Varicoloured laterally continuous grass-like } \\
\text { selenite crystals }\end{array}$ & $\begin{array}{l}\text { Laminated to thinly } \\
\text { bedded, locally } \\
\text { disrupted }\end{array}$ & Satinspar veins & $\begin{array}{l}\text { Salina, ephemeral } \\
\text { evaporite lake on } \\
\text { evaporitic mudflat }\end{array}$ & $\begin{array}{l}\text { Figure } \\
7 \mathrm{E}\end{array}$ \\
\hline 2 & $\begin{array}{l}\text { Grey mudstone to grainstone; dolomitic } \\
\text { mudstone to grainstone; quartz arenite lenses }\end{array}$ & $\begin{array}{l}\text { Laminated to thickly } \\
\text { bedded or hummocky } \\
\text { cross-stratified (HCS) }\end{array}$ & $\begin{array}{l}\text { Molar-tooth, } \\
\text { calcareous nodules } \\
\pm \text { silicified }\end{array}$ & $\begin{array}{l}\text { Shallow subtidal, } \\
\text { carbonate dominated } \\
\text { shelf }\end{array}$ & $\begin{array}{l}\text { Figure } \\
8 \mathrm{~A}\end{array}$ \\
\hline 3 & $\begin{array}{l}\text { Light to dark grey laterally linked hemispheroid } \\
\text { (LLH) and vertically stacked hemispheroid (SH) } \\
\text { stromatolitic limestone }\end{array}$ & $\begin{array}{l}\text { Millimetric } \\
\text { laminations, crinkled } \\
\text { laminations. }\end{array}$ & & $\begin{array}{l}\text { Intertidal/subtidal, } \\
\text { carbonate dominated } \\
\text { shelf }\end{array}$ & $\begin{array}{l}\text { Figure } \\
8 B, C \\
D, E, F \\
\end{array}$ \\
\hline 4 & $\begin{array}{l}\text { Dark grey to black claystone; black mudstone; } \\
\text { rhythmically interbedded mudstone and } \\
\text { argillaceous mudstone (marl) }\end{array}$ & $\begin{array}{l}\text { Laminated to thinly } \\
\text { bedded }\end{array}$ & $\begin{array}{l}\text { Ellipsoidal chert } \\
\text { concretions }\end{array}$ & $\begin{array}{l}\text { Offshore, below } \\
\text { storm wave base }\end{array}$ & $\begin{array}{l}\text { Figure } \\
9 A, B\end{array}$ \\
\hline 5 & $\begin{array}{l}\text { Red and green siltstone/claystone; quartz } \\
\text { arenite lenses; intermittent dolomitic } \\
\text { grainstone }\end{array}$ & $\begin{array}{l}\text { Laminated to thinly } \\
\text { bedded; lenticular }\end{array}$ & Desiccation cracks & $\begin{array}{l}\text { Supratidal/intertidal } \\
\text { mudflat, siliciclastic } \\
\text { dominated shelf }\end{array}$ & $\begin{array}{l}\text { Figure } \\
9 C,\end{array}$ \\
\hline
\end{tabular}

Table 1 (continued) 


\begin{tabular}{|c|c|c|c|c|c|}
\hline Lithofacies & Lithology & Bedding & Structures & $\begin{array}{l}\text { Depositional } \\
\text { environment } \\
\text { (see Figure 6) } \\
\end{array}$ & Photos \\
\hline $6-1$ & Blue-grey, very fine-grained quartzwacke & $\begin{array}{l}\text { Laminated to thinly } \\
\text { Bedded; lenticular }\end{array}$ & $\begin{array}{l}\text { Pervasive halite } \\
\text { casts }\end{array}$ & $\begin{array}{l}\text { Intertidal/lagoonal, } \\
\text { restricted, siliciclastic } \\
\text { dominated shelf }\end{array}$ & $\begin{array}{l}\text { Figure } \\
9 \mathrm{D}\end{array}$ \\
\hline $6-11$ & $\begin{array}{l}\text { Fine- to medium-grained quartz arenite with } \\
\text { minor interstratified siltstone/claystone }\end{array}$ & $\begin{array}{l}\text { Thin plane bedded } \\
\text { and ripple and dune } \\
\text { cross-stratified }\end{array}$ & Desiccation cracks & $\begin{array}{l}\text { Beach face, } \\
\text { siliciclastic dominated } \\
\text { shelf }\end{array}$ & $\begin{array}{l}\text { Figure } \\
10 \mathrm{C}\end{array}$ \\
\hline $6-I I I$ & $\begin{array}{l}\text { Couplets of equally thick, fine- to medium- } \\
\text { grained quartz arenite and siltstone/claystone }\end{array}$ & $\begin{array}{l}\text { Laminated to thinly } \\
\text { bedded }\end{array}$ & Syneraesis cracks & $\begin{array}{l}\text { Intertidal, siliciclastic } \\
\text { dominated shelf }\end{array}$ & $\begin{array}{l}\text { Figure } \\
9 E, G, \\
H\end{array}$ \\
\hline $6-I V$ & $\begin{array}{l}\text { Dark siltstone/claystone with minor quartz } \\
\text { arenite interbeds }\end{array}$ & Laminated or massive & & $\begin{array}{l}\text { Subtidal, siliclastic } \\
\text { dominated shelf }\end{array}$ & $\begin{array}{l}\text { Figure } \\
10 \mathrm{~A}, \mathrm{~B}\end{array}$ \\
\hline 7 & $\begin{array}{l}\text { Tan grainstone, packstone and mudstone } \\
\text { composed of either dolomite or calcite, } \\
\text { monomictic, framework- supported flat- } \\
\text { pebble conglomerate }\end{array}$ & $\begin{array}{l}\text { Medium-thickly } \\
\text { bedded; dune and } \\
\text { ripple cross-stratified; } \\
\text { rare, graded, upward- } \\
\text { fining beds. }\end{array}$ & $\begin{array}{l}\text { Scours, gutter } \\
\text { casts, desiccation } \\
\text { cracks }\end{array}$ & $\begin{array}{l}\text { Supratidal/Intertidal, } \\
\text { carbonate dominated } \\
\text { shelf }\end{array}$ & $\begin{array}{l}\text { Figure } \\
10 D, E, \\
F\end{array}$ \\
\hline
\end{tabular}




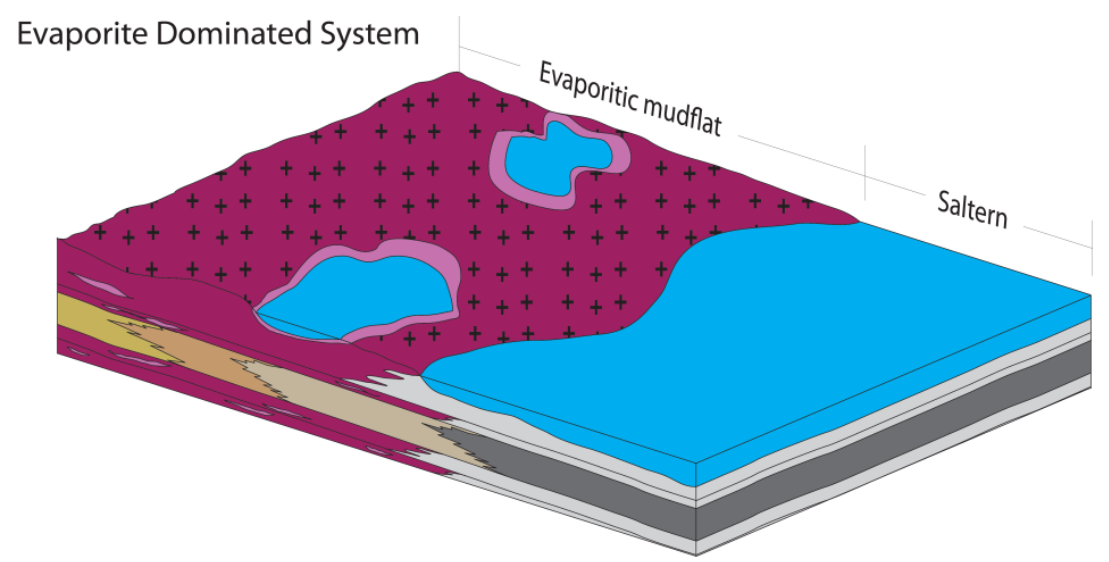

Carbonate Dominated System
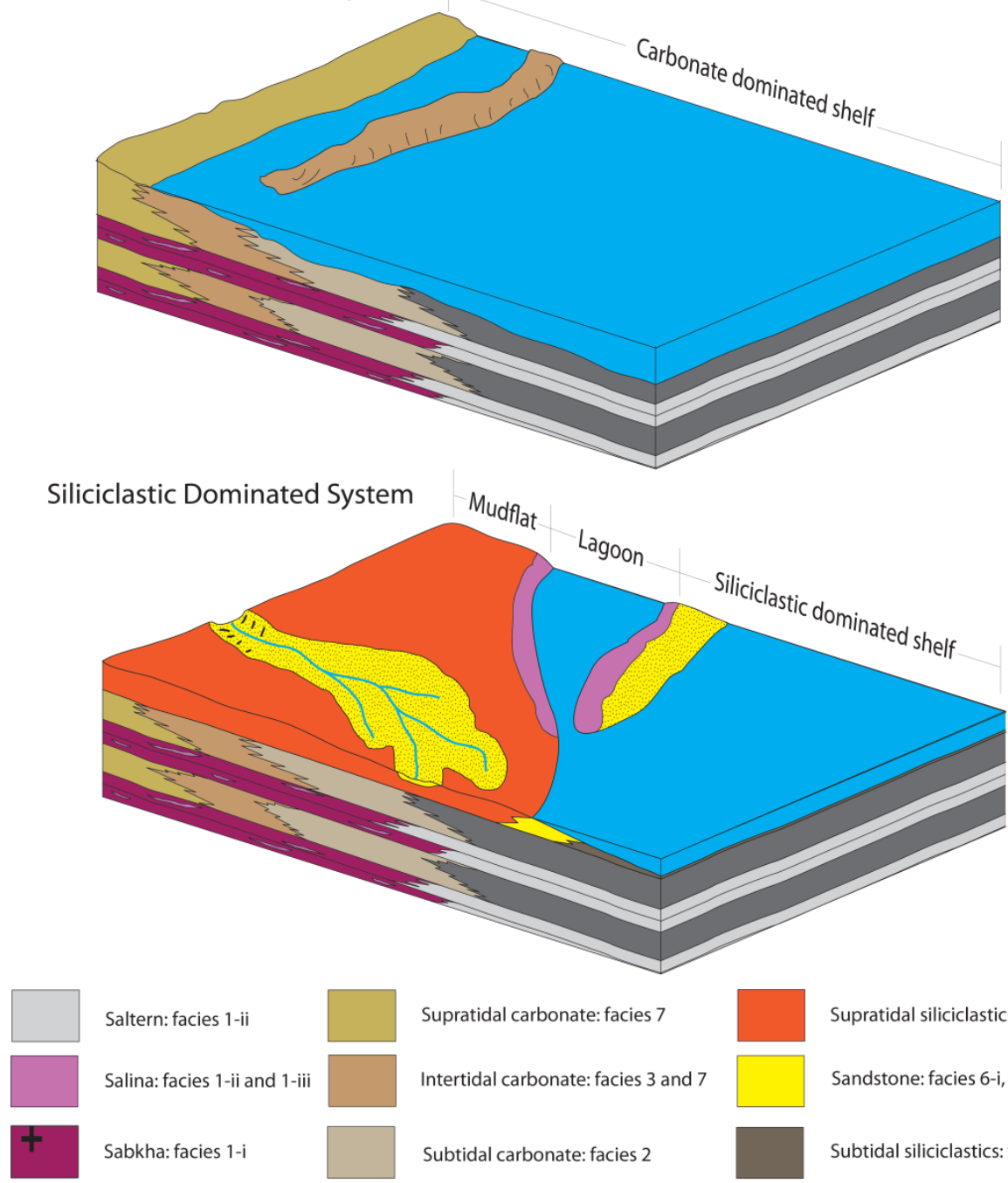

Saltern: facies 1-ii

Salina: facies 1-ii and 1-iii

Sabkha: facies 1-i

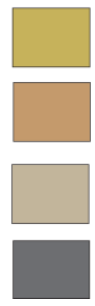

Supratidal carbonate: facies 7

Intertidal carbonate: facies 3 and 7

Subtidal carbonate: facies 2

Offshore: facies 4
Supratidal siliciclastics: facies 5

Sandstone: facies 6-i, 6-ii and 6-iii

Subtidal siliciclastics: facies 6-ii and 6-iv

Figure 6: Inferred depositional environments and distribution of facies in the Minto Inlet and Kilian formations. 
Figure 7: A) Exposure of friable, gypsiferous, maroon siltsone representative of facies 1I. B) Chicken-wire texture anhydrite in the Minto Inlet Formation (see Murray, 1964; Hardie et al., 1985; Schreiber and Tabakh, 2000 for discussion on the formation of this texture). C) Cross-stratified quartz arenite bed with gypsum clast pseudomorphs along bedding planes. D) laminated gypsarenite showing disrupted mud laminae (dark horizons). E) "Grass-like" selenite crystal laminations interstratified with siliciclastic mud. G) Ripple cross-laminations in gypsarenite beds. The cross-laminations are highlighted by quartz silt and sand laminae; the gypsum has been recrystallized. $H$ ) Laminated to thinly bedded red and green siltstone with bedding parallel satinspar veins in the lower evaporite member of the Kilian Formation. 

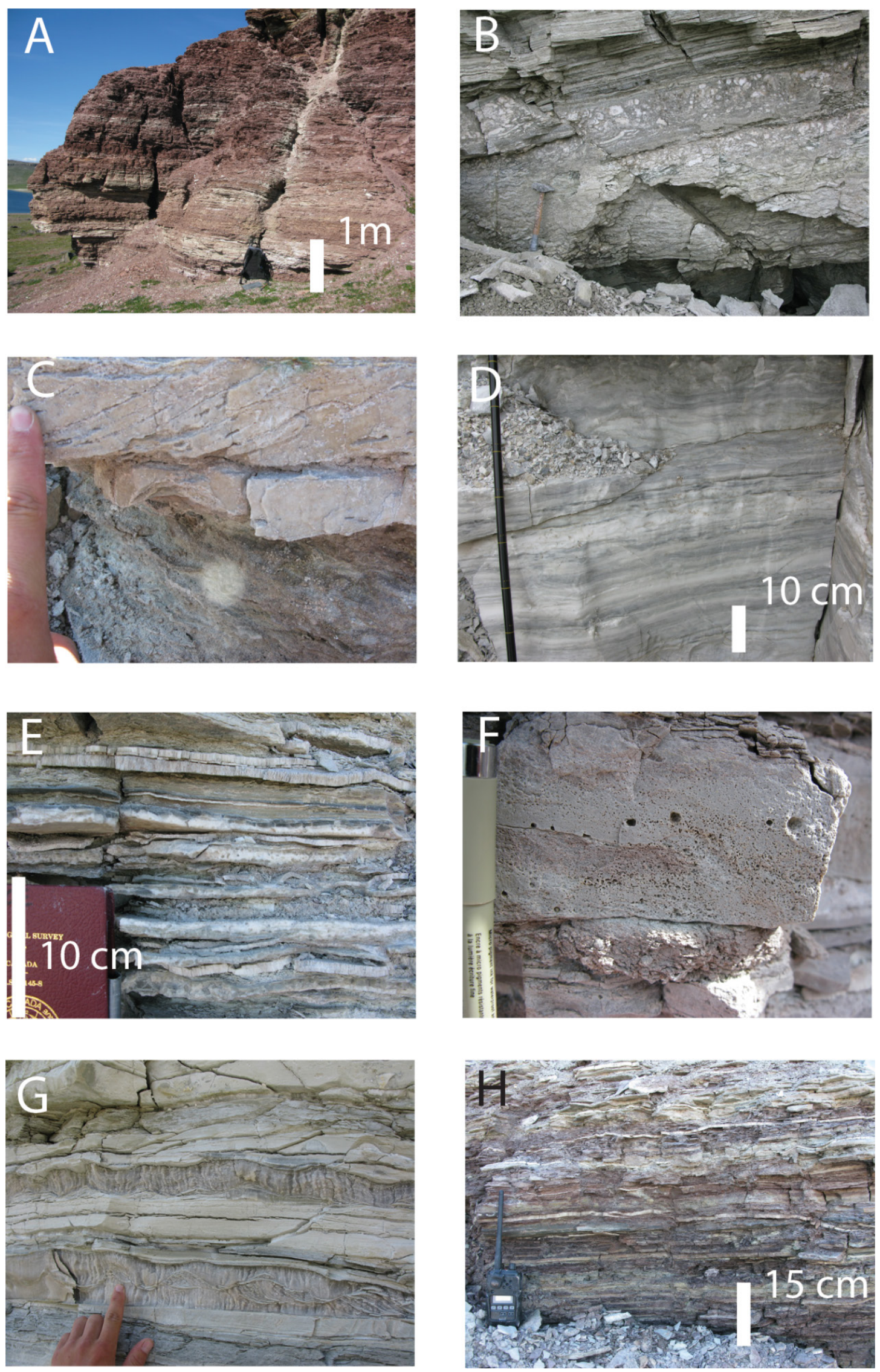
Figure 8: A) Molar-tooth structure in grainstone of the lower cyclic carbonate member of the Kilian Formation. B) Decimetric LLH stromatolites in the lower cyclic carbonate member of the Kilian Formation. C) Centimetric SH stromatolites in the upper cyclcic carbonate member, middle Kilian Formation. D) LLH stromatolites overlain by compositionally similar rhythmically interbedded mudstone and marl. E) Crinkled laminations (possibly microbial) in mudstone. Here the laminations have been replaced with silica and have positive relief. F) Decimetric SS stromatolite accumulation partially replaced by silica, subsequently altered to serpentine. 

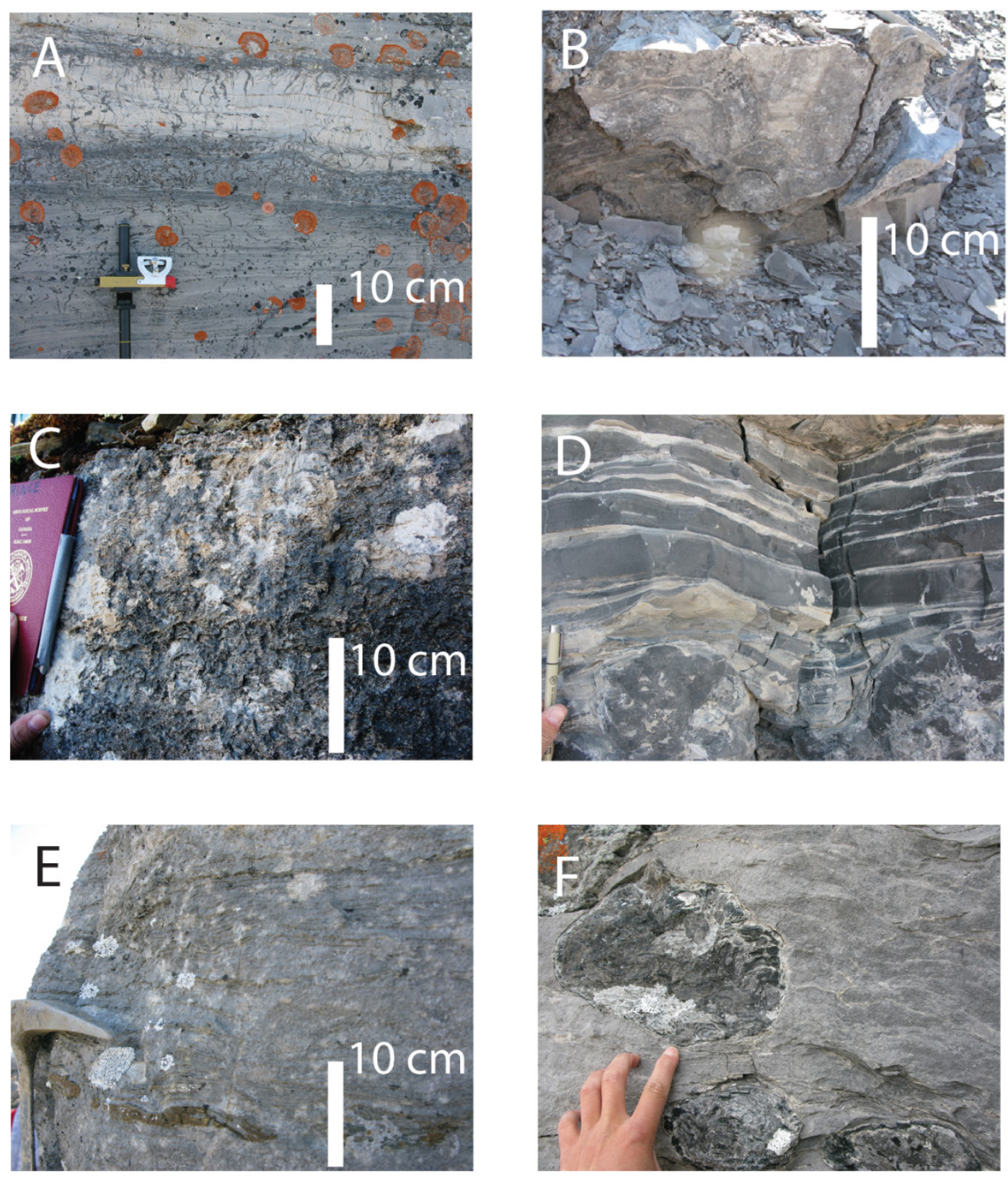
Figure 9: A) Ellipsoidal chert concretions within sub-tidal mudstone, upper cyclic carbonate member, Kilian Formation. B) Laminated black mudstone and claystone, upper cyclic carbonate member, middle Kilian Formation. C) Red and green shales of the clastic-carbonate member, Kilian Formation. Colour is controlled by diagenetic oxidation/reduction of iron. D) Millimetric cubic halite casts on the underside of a finegrained quartz arenite bed, clastic-carbonate member, Kilian Formation. Desiccation cracks are also present on the same bedding plane. E) Regularly interlaminated mud (dark laminae) and sand (light laminae) in the clastic-carbonate member interpreted as tidal rhythmites. Book is $20 \mathrm{~cm}$ tall. F) Ripple cross-stratified quartz arenite and siltstone interbedded with planar quartz arenite, pen is $\sim 15 \mathrm{~cm}$ tall. G) and H) Enigmatic structures in the clastic-carbonate member of the Kilian Formation, interpreted as syneraesis cracks. The deformation of the strata both above and below the structure is the result of differential compaction of the mud and sand laminae around sand-filled crack during lithification. 

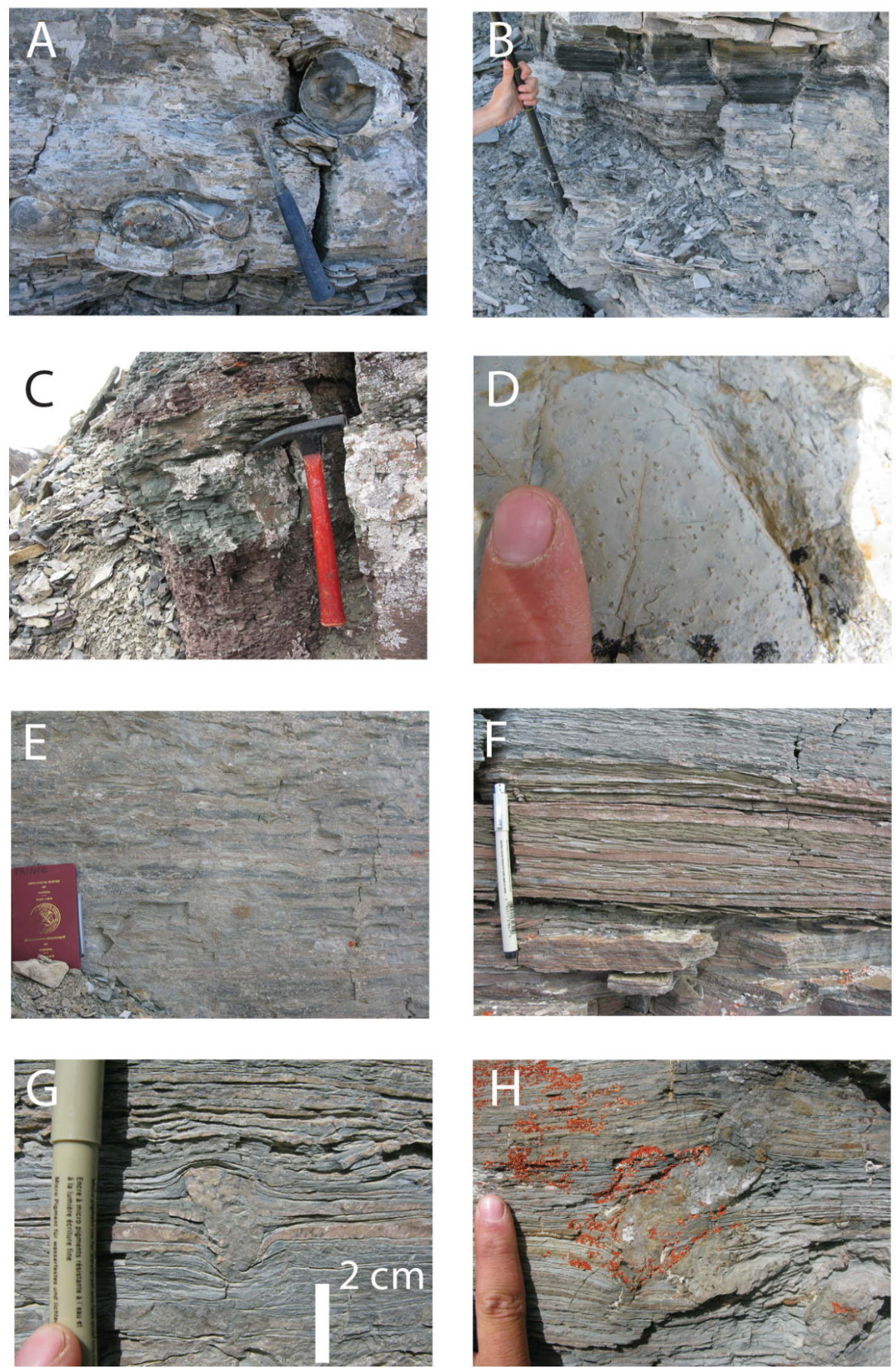
Figure 10: A) Dark, laminated, claystone and siltstone in the clastic-carbonate member, middle Kilian Formation. B) Repetitive accumulations of siltstone/claystone and quartz arenite in the clastic-carbonate member of the Kilian Formation. C) Cross-stratified, medium-grained, texturally mature, quartz arenite in the clastic-carbonate member of the Kilian Formation. D) Sharp-based, lenticular bed of dolomitic grainstone scoured into laminated, dolomitic mudstone. E) Monomictic, framework-supported, flat-pebble conglomerate interstratified in the uppermost tan carbonate member. E) Tan dolostone near the top of the tan carbonate member of the Kilian Formation, composed of interstratified dolomitic grainstone and dolomitic mudstone with common scours and gutter casts. 

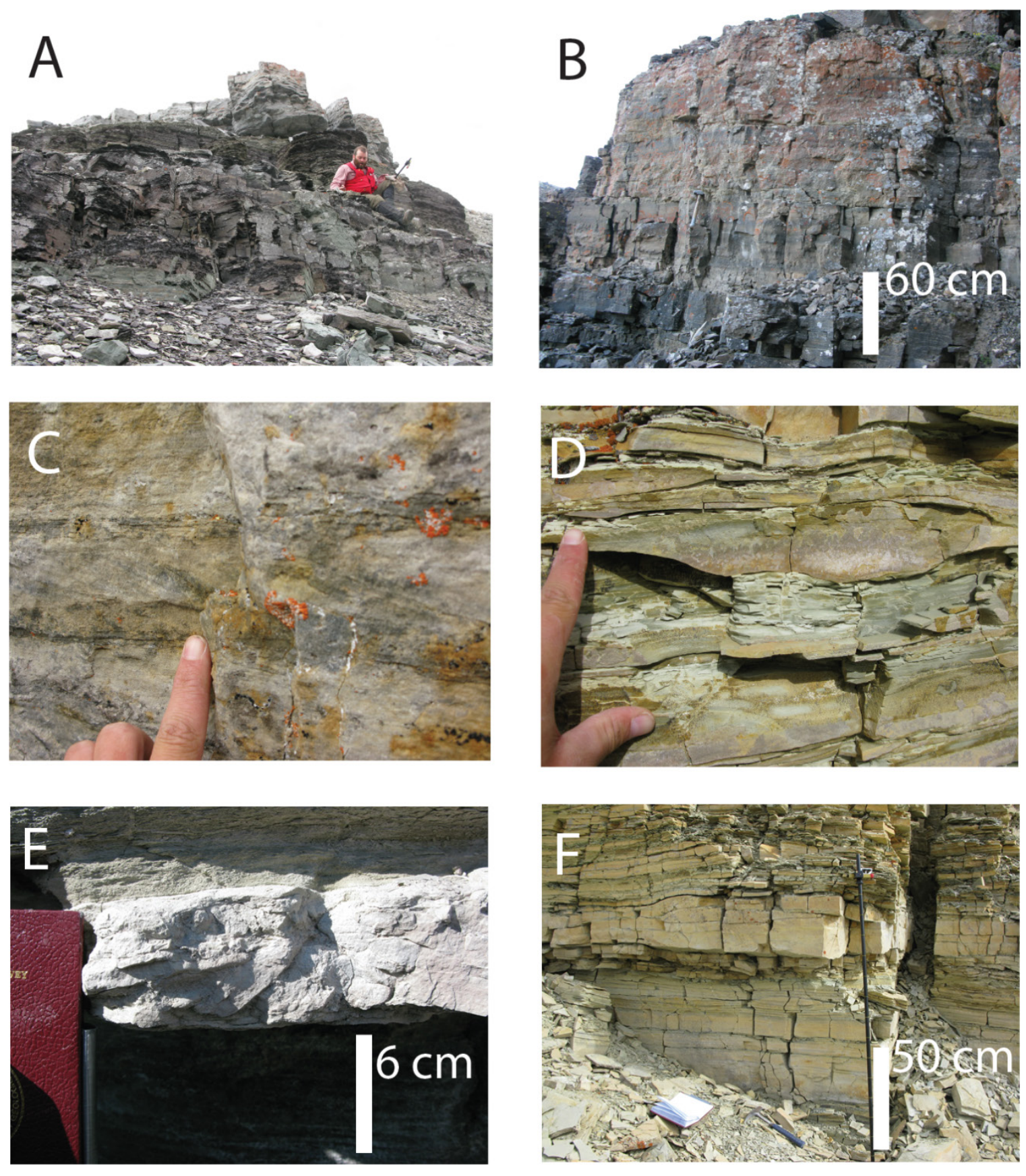


\subsection{Lithostratigraphy}

\section{The Minto Inlet Formation}

The Minto Inlet Formation is subdivided into three members, which are continuous across the Minto Inlier. In ascending order they are lower evaporite member, carbonate member and upper evaporite member (Figures 10 and 12). This subdivision is based on facies associations in the Southwest Domain as well as previous geological mapping in the Northeast Domain by Young (1981) and Phaneuf (1993).

The lower contact of the Minto Inlet Formation with the underlying Jago Bay Formation is not preserved in any of the measured sections presented here. However, field observations by the author indicate that the contact is gradational over several meters, with thin beds of white-weathering gypsum, interstratified with finely bedded mudstone, siltstone and claystone.

The lower evaporite member

Description: The lower evaporite member was measured in section 10DTS1 and in diamond drill core GNME 06-3 (Appendix 1) in the Southwest Domain, where it is 125 $\mathrm{m}$ thick and consists predominantly of friable gypsiferous claystone/siltstone of facies 1I with comparatively minor carbonate horizons of facies 2 and 3. Satinspar veins, desiccation cracks and nodular gypsum/anhydrite are common. In the Northeast Domain, the lower evaporite member 


\section{Minto Inlet Formation}

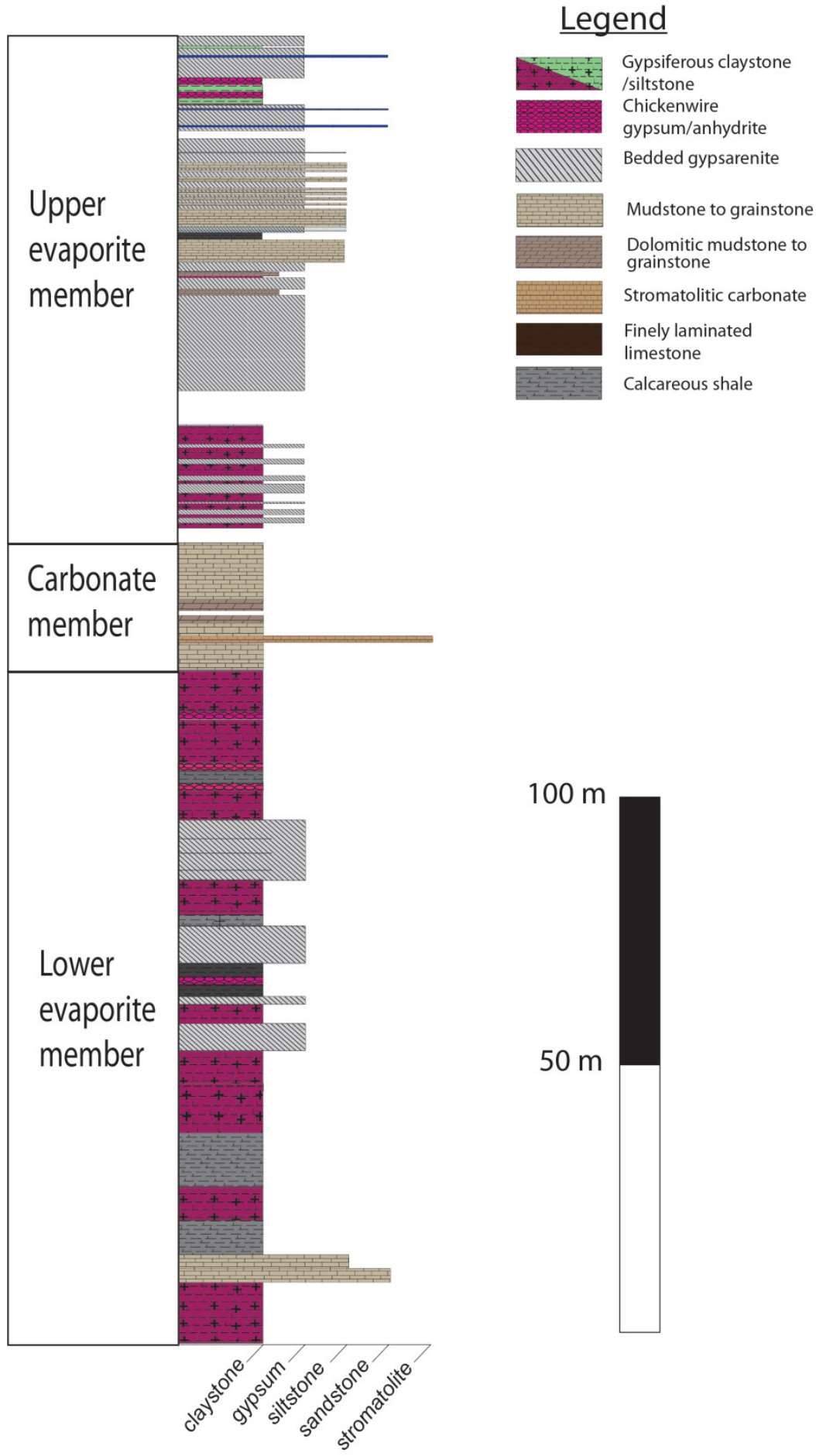

Figure 11: Composite type section of the Minto Inlet Formation from exposures in the Southwest Domain of Minto Inlier. 
is $100 \mathrm{~m}$ thick (Young, 1981; Phaneuf, 1993) and comprises considerably less

siliciclastic detritus and a higher proportion of both bedded gypsarenite of facies 1-II and carbonate of facies 2 and 3 than in the Southwest Domain. A distinctive carbonate unit (lower carbonate member of Phaneuf, 1993) about $20 \mathrm{~m}$ above the basal contact, is $\sim 25 \mathrm{~m}$ thick and composed of dark-grey dolomitic siltstone, wackestone and grainstone. Nearby, where it was measured by Young (1981), the carbonate unit is $\sim 20 \mathrm{~m}$ thick and consists of grainstone, flat-pebble conglomerates and stromatolitic limestone. In the Southwest Domain the carbonate marker unit was only observed in drill core (Appendix 1), where it is $\sim 25 \mathrm{~m}$ thick, and composed of grainstone and mudstone of facies 2 overlain by interbedded calcareous shales of facies 5 and gypsiferous siltstones of facies 1-I. Because this interval may easily be mistaken in the Southwest Domain for one of the many other carbonate interbeds, it has been included with the basal member. There is a definite increase in bedded gypsum of facies 1-II above the carbonate marker in both the Northeast and Southwest domains; some individual beds reaching thicknesses $>5 \mathrm{~m}$. The top of the lower evaporite member is characterized by thick accumulations of red siltstone of facies 1-I in the Southwest Domain, while in the Northeast Domain this interval is characterized by a higher proportion of bedded gypsum of facies 1-II.

Interpretation: The abundance of displacive gypsum/anhydrite nodules and common desiccation cracks, ripple cross-lamination and quartz arenite lenses in the lower evaporite member reflect sabkha style deposition on a an inter-tidal to supra-tidal evaporitic mud flat (Warren, 1991). The frequent interstratification of thinly bedded gypsum in both the Southwest and Northeast domains are interpreted to reflect salina 
style deposition (Warren and Kendall, 1985), which together with the sabkha deposits characterize an evaporitic mudflat depositional setting (Warren, 1991; Figure 6). Thickly bedded ( $>5 \mathrm{~m}$ ) gypsum/anhydrite above the carbonate marker is interpreted as a shallow, subaqueous, saltern-style evaporite deposit (Warren, 2010). The close association of evaporite facies 1-I and 1-II with carbonates of facies 2 and 3 in the lower evaporite member is consistent with deposition in an evaporite-dominated system (Figure 6).

The carbonate member

Description: The carbonate member was measured at 10DTS1 and in diamond drill core GNME 06-3 (Appendix 1) and varies in thickness from 27 $\mathrm{m}$ in GNME 06-3 to 14 $\mathrm{m}$ at 10DTS1. In the Northeast Domain, it is thicker, $55 \mathrm{~m}$ (Young, 1981) to $46 \mathrm{~m}$ (Phaneuf, 1993), and consists of varying amounts of grey dolomitic mudstone, wackestone and grainstone, with minor gypsum/anhydrite and siltstone interbeds. According to Young (1981), rocks of the carbonate member consist predominantly of flat-chip conglomerate, crossbedded grainstone and rare stromatolites. In the Southwest Domain, the carbonate member consists mostly of dark-grey mudstone and wackestone with molar-tooth structure of facies 2 . The lower contact of the carbonate member is not exposed at section 10DTS1. In drill core, there is a thin diabase sill which intrudes at this interval. There is no evidence of a transitional contact, suggesting abrupt freshening of the basin at this interval. 
Interpretation: The contact between the lower evaporite and the carbonate members is interpreted as a flooding surface. Molar-tooth structure is common in carbonate member exposures in the Southwest Domain and is interpreted to reflect deposition in a shallow, sub-tidal environment (James et al., 1998 and references therein). In the Northeast Domain, the interstratification of gypsum with carbonate, the presence of flat-pebble conglomerates and cross-stratified grainstone (Young, 1981) suggest a shallower, higher energy depositional environment (e.g. Sepkoski, 1982; Lewis, 1984).

The upper evaporite member

Description: The upper evaporite member is at least $50 \mathrm{~m}$ thick in the Southwest Domain at section 10DTS2 (Appendix 1) and up to $90 \mathrm{~m}$ thick in the Northeast Domain (Phaneuf, 1993). Of the three members of the Minto Inlet Formation, the upper evaporite member is perhaps the most regionally consistent and recognizable being composed of cyclically alternating medium-thick beds of white gypsum/anhydrite of facies 1-II and grey-green mudstone of facies 2 (Figure 12). The carbonate-evaporite cycles are typically 1-4 m thick but locally can exceed $10 \mathrm{~m}$. The lower contact is not exposed in the Southwest Domain but was described by Phaneuf (1993), who noted an intraformational rudite breccia at this interval. At the base of section 10DTS2, 1-5 m thick accumulations of finely laminated gypsum are overlain by rhythmic accumulations of nodular-bedded gypsum and mudstone. A repetitive succession, characterized by a $10-100 \mathrm{~cm}$ thick bed of mudstone or dolomitic mudstone overlain by a similar thickness 
of bedded to nodular gypsum/anhydrite, usually intercalated with claystone or siltstone.

Young (1981) studied 179 such transitions between carbonate and
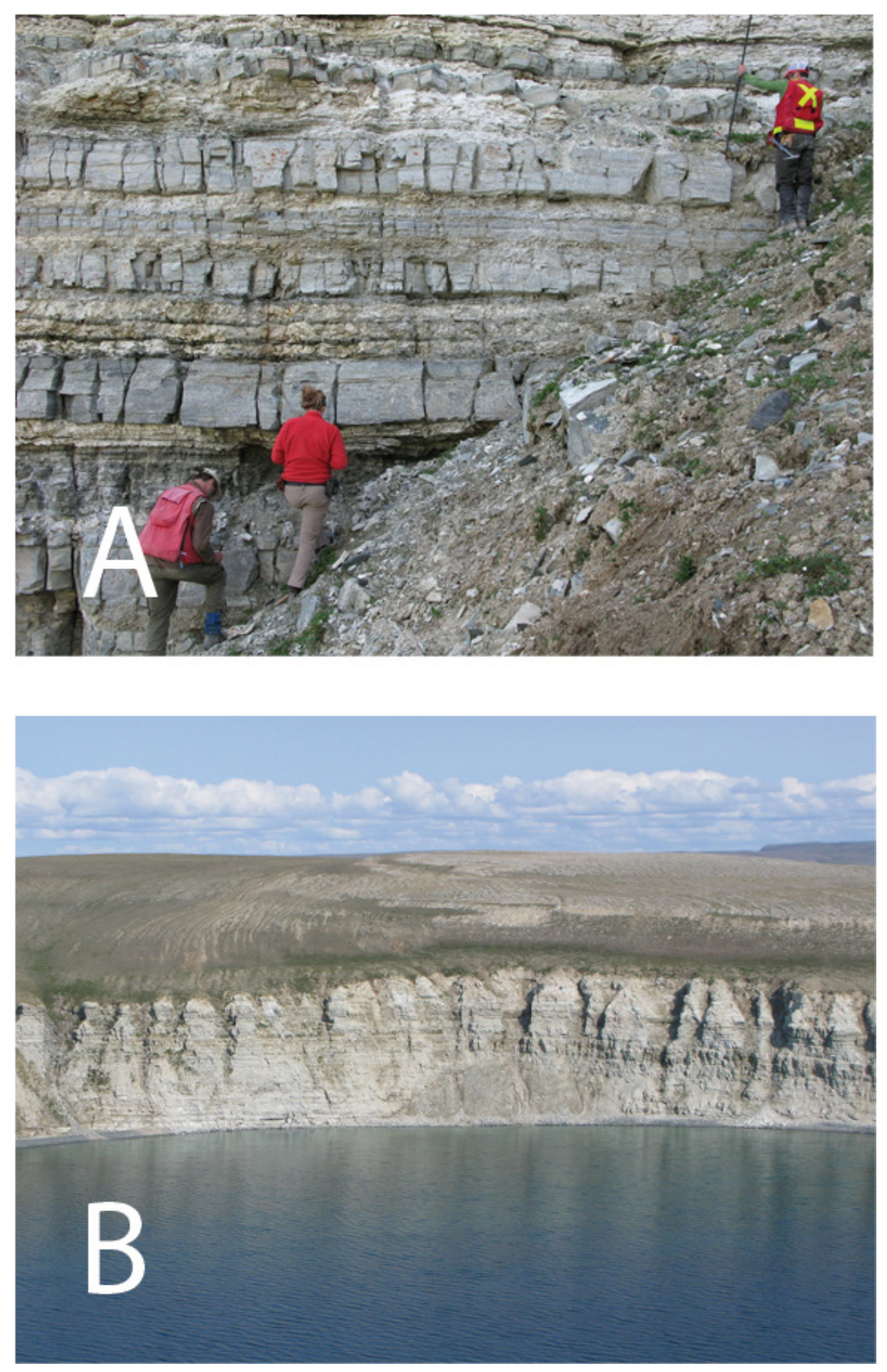

Figure 12: A) Carbonate-evaporite cycles in the upper evaporite member of the Minto Inlet Formation. B) Thickly bedded gypsum/anhydrite in the upper evaporite member of the Minto Inlet Formation. Cliff is $\sim 45 \mathrm{~m}$ tall. 
evaporite beds in the upper evaporite member and described the cyclical nature using the analytical method of Cant and Walker (1976).

Interpretation: The thick accumulation of gypsum and anhydrite in the stratigraphically lowest observed exposures of the upper evaporite member represent prolonged periods where gypsum saturation was maintained (Sonnenfeld, 1979). Carbonateevaporite cycles like those preserved in the upper evaporite member are well documented in Phanerozoic saltern-style evaporites (Permian San Andres Formation, Delaware, USA; Elliott and Warren, 1989; Jurassic Hith Anhydrite, Middle East; Alsharhan and Kendall, 1994; Cretaceous Ferry Lake anhydrite, USA; Petty, 1995) and are thought to reflect $4^{\text {th }}$ order $(\sim 100,000 \mathrm{yr})$ glacio-eustatic sea level changes (Warren, 2010). Since carbonate is less soluble than sulphate in sea water, it reaches saturation and precipitates earlier than sulphate during evaporation (Briggs, 1958). Original parallel stratification of gypsum beds has been disrupted by diagenetic alteration of gypsum to anhydrite and vice versa, this process accounts for the observed nodules and enterolithic folding but lack of desiccation features (see Warren and Kendall, 1985).

The contact of the Minto Inlet Formation with the overlying Wynniatt Formation was not observed in any of the stratigraphic sections or in the drill core. In rubbly outcrop on the south side of Minto Inlet there is a thin $(2-3 \mathrm{~m})$ diabase sill intruding near the contact horizon, separating bedded gypsum beneath and shallow water carbonates of the lower carbonate member of the Wynniatt Formation above. The contact is inferred to be conformable, representing transgression. 


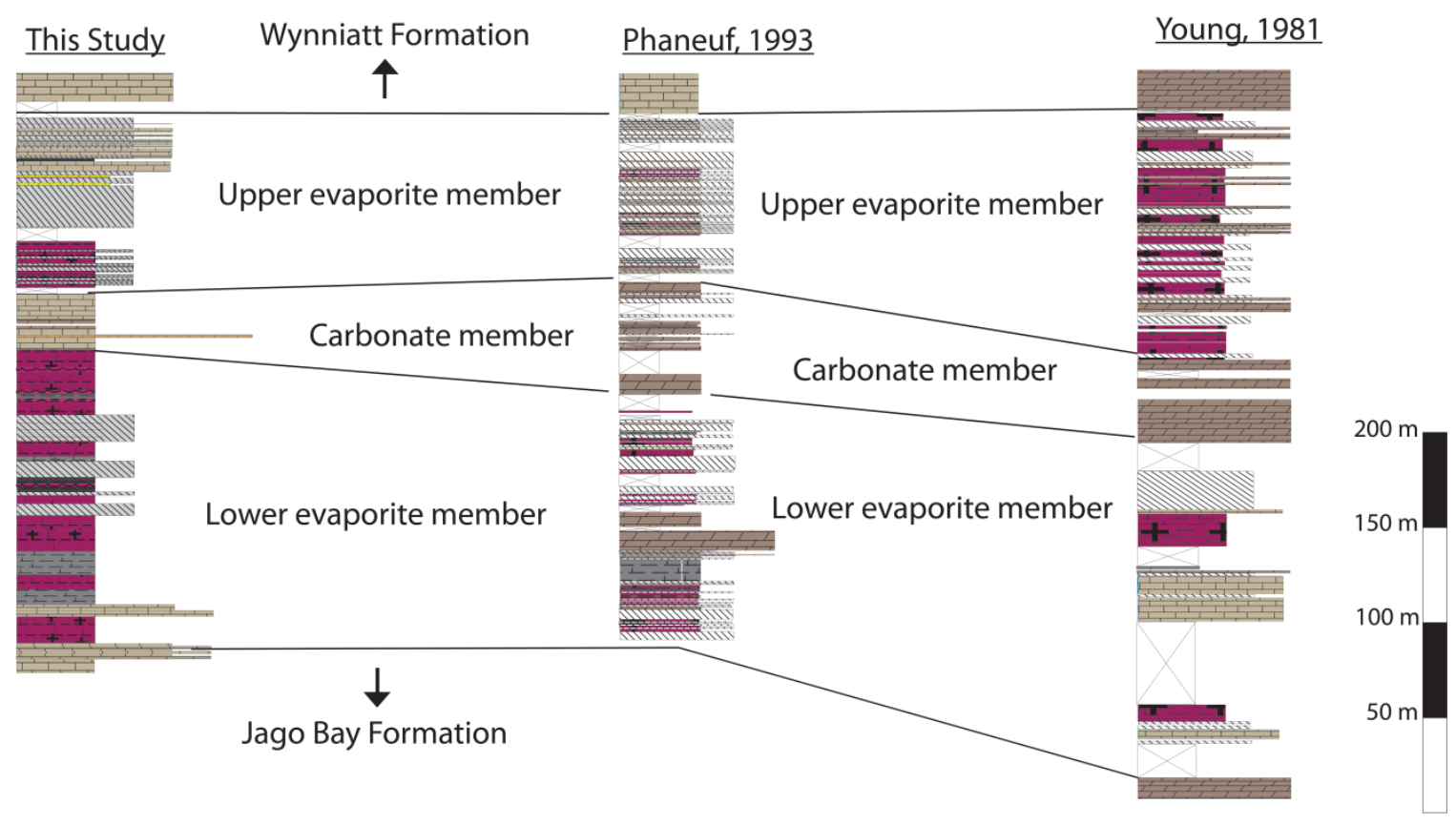

Legend

$\begin{array}{ll}\begin{array}{l}\text { Gypsiferous claystone } \\ \text { /siltstone }\end{array} & \begin{array}{l}\text { Mudstone to grainstone } \\ \text { Chickenwire } \\ \text { gypsum/anhydrite }\end{array} \\ \text { Bolomitic mudstone to } \\ \text { grainstone }\end{array}$

Figure 13: Lithostratigraphic correlation of the Minto Inlet Formation across the Minto Inlier. Stratigraphic sections from Phaneuf (1993) and Young (1981) were modified according to the lithofacies defined in this work.

\section{The Kilian Formation}

The present study adds to and refines the general lithostratigraphic succession proposed by Rainbird (1991) including the subdivision of the Kilian Formation into 8 members (Figure 14). In stratigraphic order; these are the lower evaporite, lower cyclic carbonate, middle evaporite, upper cyclic carbonate, clastic-carbonate, tan carbonate, upper evaporite and red shaly carbonate members (Table 2). 
Table 2: Lithostratigraphy of the Kilian Formation

\begin{tabular}{|c|c|c|c|}
\hline Member & Thickness & Description & Depositional environment \\
\hline $\begin{array}{l}\text { Lower } \\
\text { evaporite } \\
\text { member }\end{array}$ & $\sim 40 \mathrm{~m}$ & $\begin{array}{l}\text { Gypsum rich, red and green siltstone/claystone with displacive evaporite } \\
\text { nodules, desiccation cracks, satinspar veins and sparse, cross-stratified quartz } \\
\text { arenite lenses and (facies 1-I; Table 1); rare, thinly-bedded, coarse-grained } \\
\text { selenite (facies 1-III; Table 1); minor, thinly bedded or laminated carbonate } \\
\text { (facies 3) }\end{array}$ & $\begin{array}{l}\text { Intertidal to supratidal } \\
\text { evaporitic mudflat } \\
\text { (Rainbird, 1991). }\end{array}$ \\
\hline $\begin{array}{l}\text { Lower } \\
\text { cyclic } \\
\text { carbonate } \\
\text { member }\end{array}$ & $\sim 80 \mathrm{~m}$ & $\begin{array}{l}\text { Molar-tooth and HCS limestone (facies 2; Table 1), LLH stromatolitic } \\
\text { limestone (facies 3); green, laminated siltstone and claystone (facies 5); } \\
\text { rhythmically interbedded limestone and marl (facies 4). }\end{array}$ & $\begin{array}{l}\text { Subtidal to intertidal } \\
\text { carbonate-dominated inner } \\
\text { shelf (Rainbird, 1991) }\end{array}$ \\
\hline $\begin{array}{l}\text { Middle } \\
\text { evaporite } \\
\text { member }\end{array}$ & $\sim 50 \mathrm{~m}$ & $\begin{array}{l}\text { Green shale with hopper shaped halite casts (facies 5; Table 1); thinly bedded } \\
\text { gypsarenite (facies 1-II); nodular and enterolithically folded } \\
\text { gypsum/anhydrite Northeast Domain (Rainbird, 1991) }\end{array}$ & $\begin{array}{l}\text { Intertidal to supratidal } \\
\text { evaporitic mudflat } \\
\text { (Rainbird, 1991) }\end{array}$ \\
\hline $\begin{array}{l}\text { Upper } \\
\text { cyclic } \\
\text { carbonate } \\
\text { member }\end{array}$ & $\sim 140 \mathrm{~m}$ & $\begin{array}{l}\text { Grey, finely laminated, stromatolitic (LLH and SH) limestone (facies 3; Table } \\
\text { 1); rhythmically interbedded mudstone and marl (facies 4); black calcareous } \\
\text { shale (facies 4); grey to black limestone with molar-tooth structure (facies 4); } \\
\text { gypsiferous siltstone and massive gypsarenite beds (Northeast Domain only; } \\
\text { Rainbird, 1991) }\end{array}$ & $\begin{array}{l}\text { Offshore, subtidal and } \\
\text { intertidal carbonate- } \\
\text { dominated middle to inner } \\
\text { shelf (Rainbird, 1991) }\end{array}$ \\
\hline $\begin{array}{l}\text { Clastic } \\
\text { carbonate } \\
\text { member }\end{array}$ & $\sim 80 \mathrm{~m}$ & $\begin{array}{l}\text { Laminated blue-grey quartzwacke with desiccation cracks and halite casts } \\
\text { (facies 6-I; Table 1; Figure 9D); siltstone/claystone and fine- to medium- } \\
\text { grained quartz arenite couplets cut by synereasis cracks (facies 6-III; Figure } \\
9 \text { G and H); medium-grained quartz arenite (facies 6-II); massive, dark brown } \\
\text { siltstone/claystone (facies 6-IV); red and green shale (facies 5), cross- } \\
\text { stratified and plane bedded quartz arenite with thin siltstone/claystone } \\
\text { laminations with desiccation-cracks. }\end{array}$ & $\begin{array}{l}\text { Intertidal to supratidal } \\
\text { siliciclastic-dominated inner } \\
\text { shelf (Rainbird, 1991) }\end{array}$ \\
\hline
\end{tabular}


Table 2 (continued)

\begin{tabular}{|l|l|l|l|}
\hline Member & Thickness & Description & Depositional environment \\
\hline $\begin{array}{l}\text { Tan } \\
\text { carbonate } \\
\text { member }\end{array}$ & $\sim 50 \mathrm{~m}$ & $\begin{array}{l}\text { Tan, ripple cross-laminated grainstone with mudstone interbeds and thin, } \\
\text { sharp-based, upward-fining grainstone to mudstone beds (facies 7; Table 1); } \\
\text { finely laminated stromatolitic limestone (facies 3). Scours, gutter casts, } \\
\text { desiccation cracks and thin, lenticular beds of flat-pebble, monomictic, } \\
\text { framework-supported conglomerate. }\end{array}$ & $\begin{array}{l}\text { Storm-dominated shallow } \\
\text { subtidal to intertidal } \\
\text { carbonate-dominated inner } \\
\text { shelf (Rainbird, 1991). }\end{array}$ \\
\hline $\begin{array}{l}\text { Upper } \\
\text { evaporite } \\
\text { member }\end{array}$ & $\sim 55 \mathrm{~m}$ & $\begin{array}{l}\text { Gypsiferous siltstone and nodular gypsum/anhydrite (facies 1-I; Table 1); thin } \\
\text { gypsarenite and grainstone containing gypsum casts (facies 1-II); grass-like } \\
\text { selenite beds (facies 1-III); thinly bedded, sharp-based grainstone and 5-20 } \\
\text { cm thick, imbricated, flat-pebble, monomictic, framework-supported } \\
\text { conglomerate (facies 7); }\end{array}$ & $\begin{array}{l}\text { Intertidal to supratidal } \\
\text { evaporitic mudflat deposits } \\
\text { (Rainbird, 1991) }\end{array}$ \\
\hline $\begin{array}{l}\text { Red shaly } \\
\text { carbonate } \\
\text { member }\end{array}$ & $\sim 34 \mathrm{~m}$ & $\begin{array}{l}\text { Thin- to medium-bedded, fissile and recessive red siltstone, claystone with } \\
\text { common desiccation cracks and minor dolomitic grainstone (facies 5; Table } \\
\text { 1); minor interbeds of ripple and dune cross-stratified siltstone and } \\
\text { sandstone (facies 6-II). }\end{array}$ & $\begin{array}{l}\text { Supratidal storm-influenced } \\
\text { siliciclastic mudflat deposits } \\
\text { (Rainbird, 1991) }\end{array}$ \\
\hline
\end{tabular}




\section{Kilian Formation}

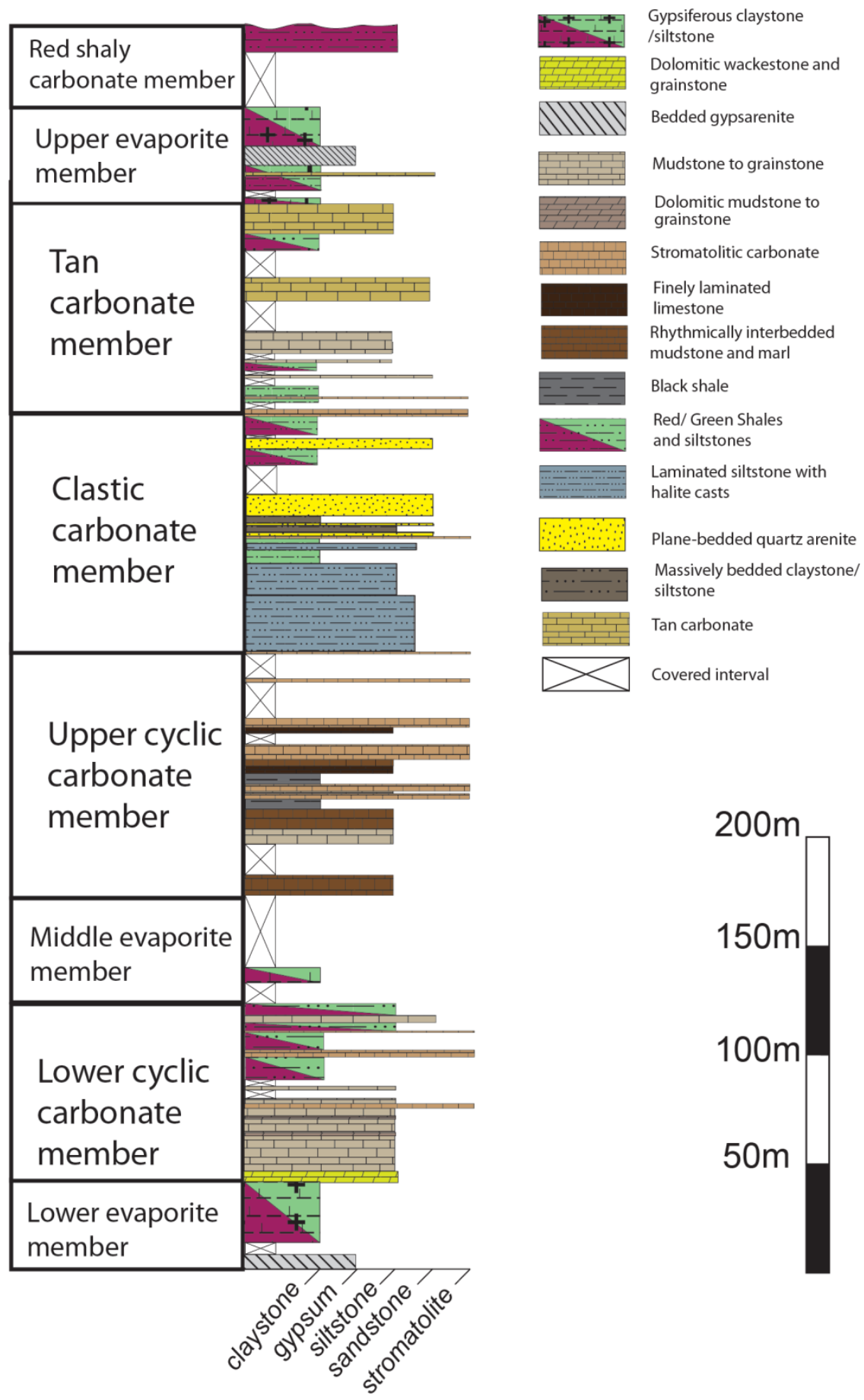

Figure 14: Composite type section of the Kilian Formation from exposures in the Southwest Domain of Minto Inlier. 
The upper contact of the Kilian Formation

Description: The contact between the Kilian Formation and the overlying Kuujjua Formation is covered at 11JPS4 but nearby, at station 11RATRR031 (Figure 5, above), it is marked by a sharp-based bed of oligomictic, framework-supported, sub-angular to sub-rounded pebble to cobble conglomerate (Figure 15B). This bed is of variable thickness $(0-30 \mathrm{~cm})$ and comprises pebble- to cobble-sized, cherty quartzite clasts in a green sandy siltstone matrix composed of fine-grained basaltic detritus. The breccia scours into the underlying laminated siltstone of the red shaly carbonate member, here altered to dark green colour with abundant pyrite and limonite. Overlying the breccia at this location is a $\sim 2$ m-thick interval of green weathering, fine-grained sandstone composed of basaltic detritus and quartz (Figure 15A, C, D). The basaltic/volcaniclastic unit is overlain by 3-4 m of massive and thickly bedded quartz arenite capped by a diabase sill (Figure 15A).

Interpretation: The conglomerate is interpreted as an epiclastic extraformational colluvial deposit based on the angularity of the clasts, its variable thickness and the presence of only one clast type (see Pettijohn et al., 1975; Boggs, 2009). The overlying volcaniclastic deposits may represent the onset of the early stages of Franklin LIP related volcanism. Previous descriptions of basalt in the upper Kilian Formation are given by Young (1981) and Rainbird (1991). Jefferson (1985) also noted an erosional lag at the base of the Kuujjua Formation in a nearby outcrop but at a location where basalt is absent. This suggests that the basalt flows were only locally distributed at this time. 

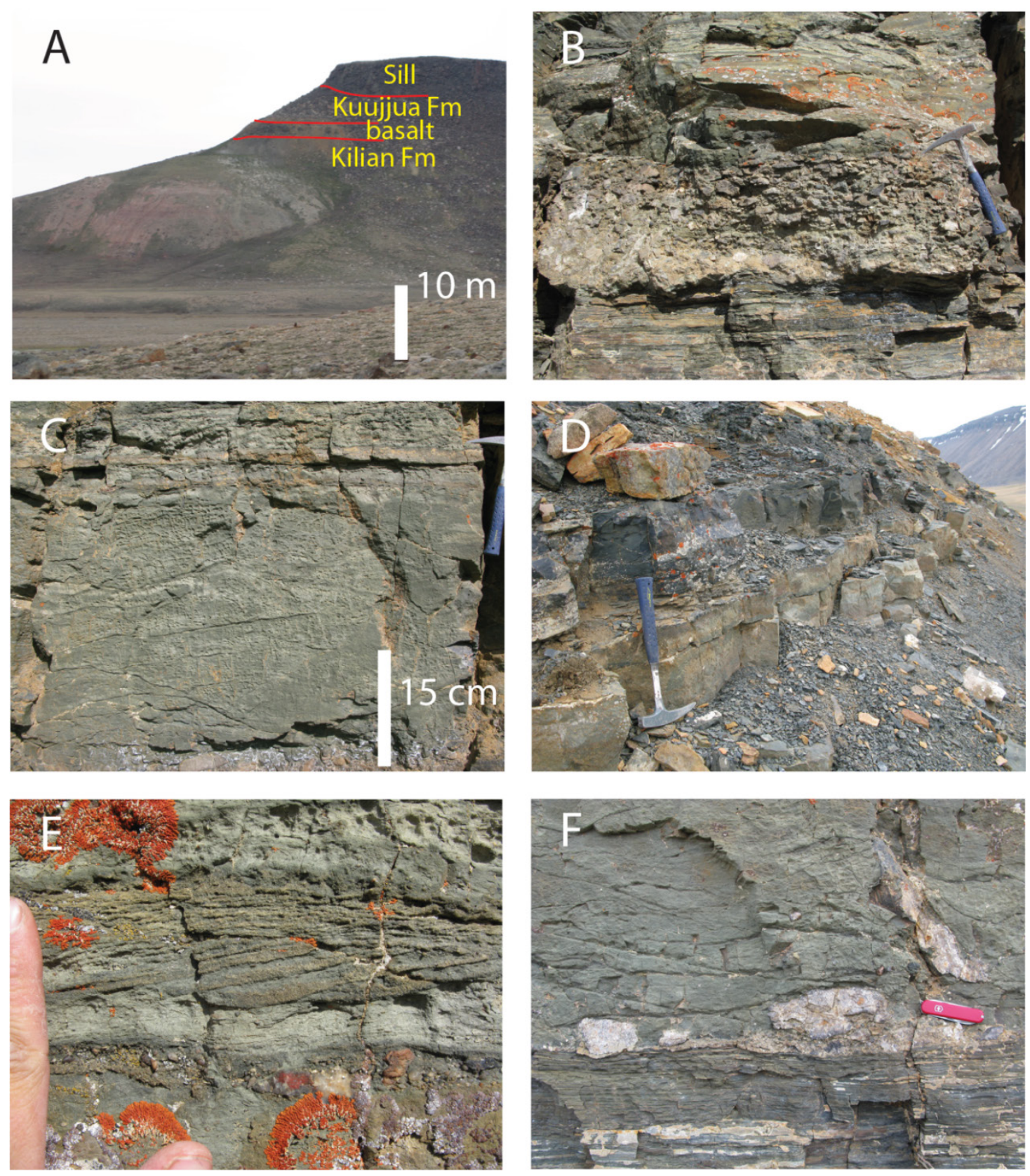

Figure 15: A) View of outcrop at station 11RATRR031 looking east at the uppermost Kilian Formation and its contact with the overlying Kuujjua Formation. B) Frameworksupported, oligomictic, pebble to cobble conglomerate at the contact between the Kilian and Kuujjua formations. C) Tefoni weathering structure giving honeycomb appearance in massive volcaniclastic sandstone/wacke. D) Sharp contact between basalt flow and plane-bedded quartz wacke. E) Cross-stratified quartz wacke from the same interval. F) Blocks of cherty quartzite along the same interval as the breccia in Figure $16 \mathrm{~B}$, here less well defined. Knife is $\sim 10 \mathrm{~cm}$ long. 


\subsection{Sequence Stratigraphy}

Sequence stratigraphy is a useful approach to sedimentary geology that allows correlation of sedimentary successions independent of lithology. It is based on the identification of important surfaces within a stratigraphic section that divide the section into discrete packages, representing natural changes in relative sea level and sediment supply. Sequence stratigraphy was developed in the mid 1970's (e.g. Vail et al., 1977) as a method for interpreting seismic stratigraphic records, and was subsequently extended to outcrops and drill cores (Posamentier et al., 1988). Since its initial conceptualization several approaches to sequence stratigraphic analysis have arisen for use in various depositional environments (Van Wagoner et al., 1988; Hunt and Tucker, 1992; Loucks and Sarg, 1993; Warren, 1999; Plint and Nummedal, 2000; Embry, 2009; Catuneanu et al., 2011).

The Minto Inlet and Kilian formations are subdivided herein based on the principles of depositional sequence stratigraphy as defined by Van Wagoner et al. (1988) modified by Hunt and Tucker (1992) and later by Plint and Nummedal (2000). Two scales of sequence stratigraphic units are recognized within the Kilian Formation, those are sequences and systems tracts. A sequence is defined as "a conformable succession of genetically related strata, bounded at base and top by unconformities or their correlative conformable surfaces" (Van Wagoner et al., 1990). A sequence can be subdivided into multiple systems tracts, each bounded by unique surfaces (Posamentier 
and Allen, 1999). These include lowstand systems tract (LST), transgressive systems tract (TST), highstand systems tract (HST) and falling stage systems tract (FSST) (Figure 16).

Systems tracts are defined by fluctuations in relative sea level or lack thereof. LSTs are deposited while relative sea level is stagnant or slowly rising implying that the rate of accommodation space generation is balanced by the rate of sediment accumulation. TSTs are deposited while relative sea level is rising and the rate of accommodation space generation exceeds the rate of sediment accumulation. When the rate of accommodation space generation begins to decrease and relative sea level is reaching its maximum HST facies are deposited. FSST sediments are deposited during forced regression while accommodation space is decreasing.
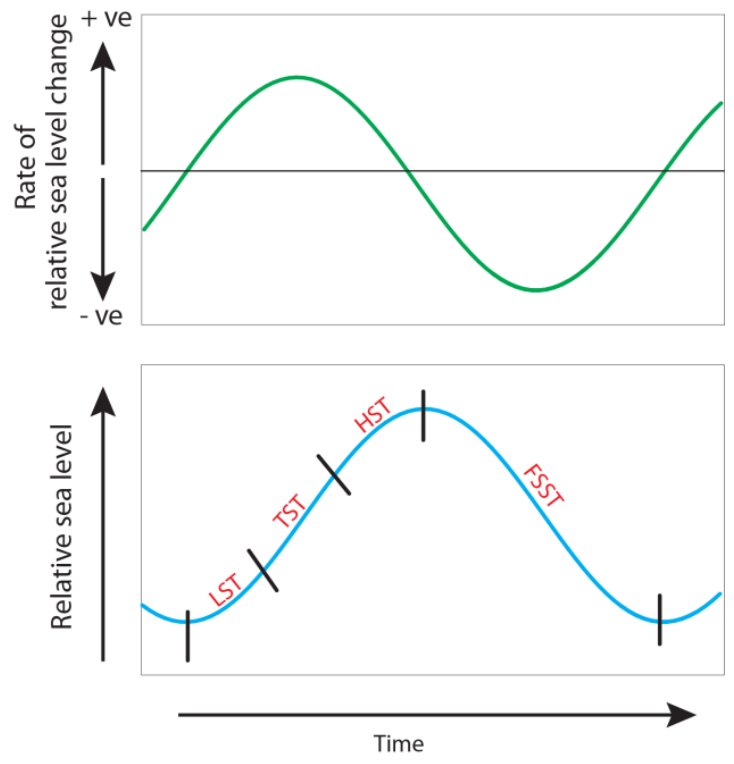

Figure 16: One cycle of relative sea level change. Showing the conditions which define each of the four systems tracts described in the text above, after Catuneanu (2006). 


\section{Sequence stratigraphic framework}

The sequence stratigraphic framework for the Proterozoic strata of northwestern Laurentia was first established by Young et al., (1979) who divided it into 3, first-order sequences: A, B and C. Rainbird et al. (1996) built upon that framework and more closely examined strata of Sequence B, which includes the Shaler Supergroup and the Mackenzie Mountains Supergroup. The sequence boundary between older Sequence A rocks and younger Sequence B rocks in Amundsen Basin is placed at the unconformity between the Shaler Supergroup and the Coppermine River Group. In the Minto Inlier, the upper bounding surface of Sequence B rocks has been placed at the contact between fluvial sandstones of the Kuujjua Formation overlying flood basalts of the Natkusiak Formation of the upper Shaler Supergroup (Young et al., 1979; Rainbird et al., 1996). Long et al. (2008) further subdivided Sequence B strata into five, secondorder sequences, B1-B5.

\section{Sequence B4}

The basal contact of the Minto Inlet Formation and upper contact of the Wynniatt Formation coincide with the upper and lower boundaries of second-order sequence B4 (Long et al., 2008; Thomson et al., 2014). Thomson et al. (2014) subdivided Sequence B4 into four transgressive-regressive cycles (Embry, 2002), B4-I to B4-IV, of which the Minto Inlet Formation and the lower $\sim 45 \mathrm{~m}$ of the lower carbonate member of the Wynniatt Formation make up the lowermost cycle. 


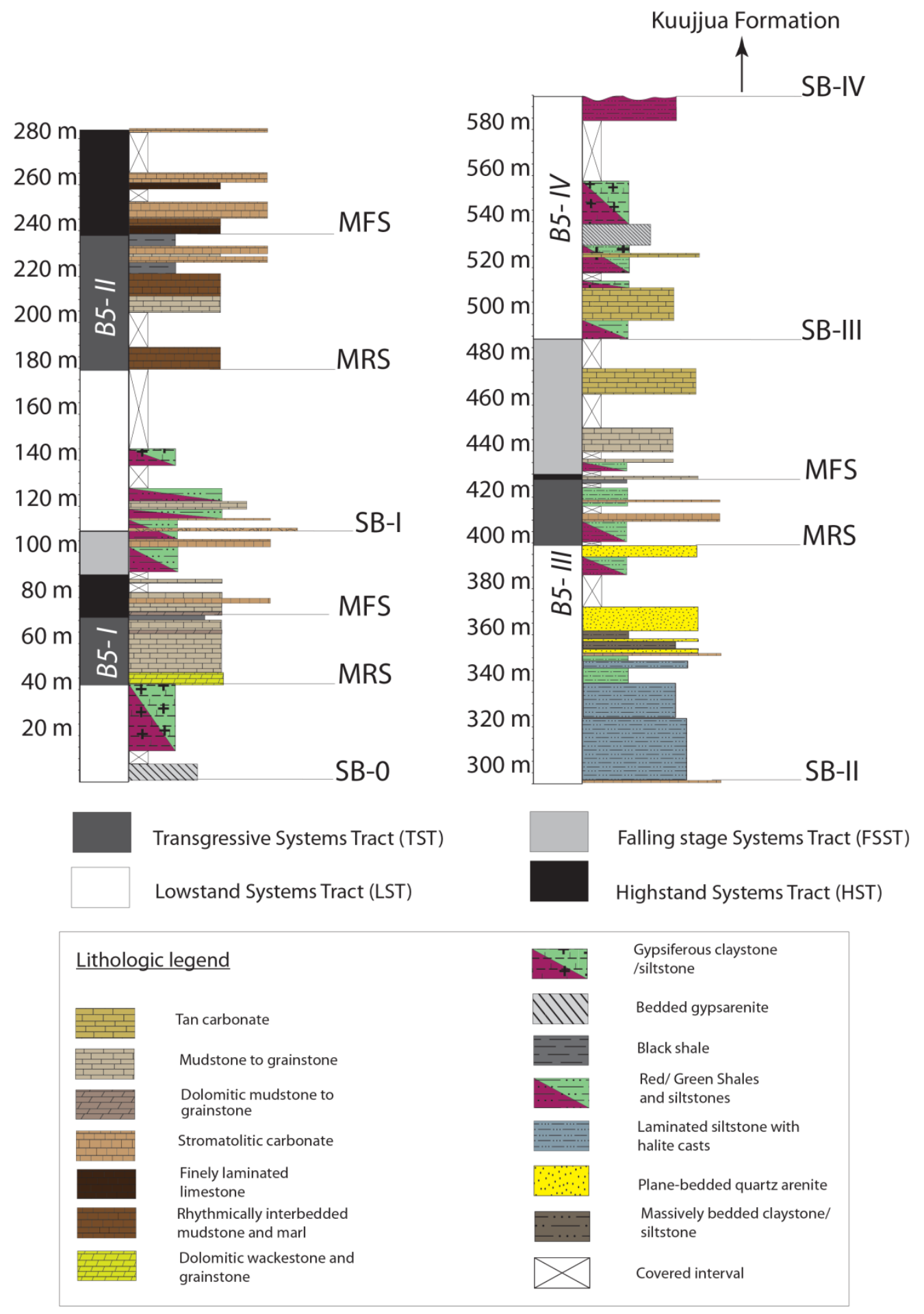

Figure 17: Sequence stratigraphy of the Kilian Formation, showing sequence boundaries (SB-0 to SB-IV), maximum regressive surfaces (MRS) and maximum flooding surfaces (MFS) which act as the boundaries for the systems tracts. 


\section{Sequence B5-I}

Sequence B5-I is bounded below by a second-order sequence boundary that coincides with the sharp lithostratigraphic contact separating marine carbonates of the Wynniatt Formation from nodular evaporites and desiccation-cracked siltstone/claystone of the Kilian Formation (Thomson et al., 2014). The upper bounding surface of sequence B5-I coincides with the erosional contact between the lower cyclic carbonate member and the middle evaporite member at $115 \mathrm{~m}$ above the basal contact of the Kilian Formation (Figure 17). The LST of sequence B5-I is dominated by desiccation-cracked, gypsiferous, red and green siltstone/claystone of facies 1-I (Table 1) interpreted to have been deposited under very shallow to emergent conditions. The maximum regressive surface (MRS) - the upper boundary of the LST-occurs at the transition from gypsiferous siltstone/claystone of facies 1-I to dolomitic grainstone of facies 1-II ( 40 m; Figure 17). Overlying the strata which make up the LST is a $4 \mathrm{~m}$-thick unit of dolomitic grainstone interlaminated with grass-like selenite. This is overlain by a $\sim 15$ m-thick unit composed of grainstone and mudstone of facies 2 with common MTS and HCS, which grades upward into a thin, recessive unit of black shale of facies 4 (Table 1) containing chert nodules. This facies stacking pattern is interpreted to reflect the TST. The maximum flooding surface (MFS) - the upper boundary of the TST - is placed at a black shale interval in the middle cyclic carbonate member (Figure 17). The HST is about 20 m-thick; its upper boundary and the transition to the FSST is placed at the transition from sub-tidal carbonates of facies 2 to inter-tidal to supra-tidal green 
siltstone/claystone facies 5 (Table 1), near the top of cyclic carbonate member. The FSST represents a forced regression and lowering of relative sea level.

\section{Sequence B5-II}

The lower bounding surface of sequence B5-II is placed at an irregular erosional surface between underlying subtidal laminated claystone/siltstone of facies 6-IV and an overlying $\sim 30 \mathrm{~cm}$-thick unit composed of quartz arenite which grades upward into a 10 cm-thick framework-supported pebble conglomerate at 115 m (Figure 17; Figure 18). The LST is dominated by green siltstone/claystone of facies 1-I and thin-bedded gypsarenite of facies 1-II interpreted to represent deposition in a shallow, restricted, salina environment. The MSR occurs under cover between 145 and 180 m (Figure 17) and is overlain by finely laminated grey mudstone and grainstone of facies 3 (Table 1). The TST of sequence B5-II is not well exposed; it comprises finely laminated and stromatolitic mudstone-grainstone of facies 2 and 3 as well as rhythmically interbedded mudstone and marl of facies 4 (Table 1 ) with a facies stacking pattern suggesting upward deepening. The MFS and the upper boundary of the TST is located in a section of dark and finely laminated shale, which is interpreted to have been deposited in an offshore, calm-water and oxygen-deficient setting (Arthur and Sageman, 1994). The HST consists of black shale, mudstone and marl of facies 4 , and finely laminated and stromatolitic mudstone of facies 3 . These facies are interpreted to reflect deposition in an offshore, sub-tidal environment. The common interstratification of stromatolitic carbonate in the HST suggests that water depths rarely exceeded that of the photic zone. There is no FSST preserved within sequence B5-II. The upper sequence boundary, 
although not exposed, is assumed to be between stromatolitic limestone of facies 2 and halite casted and dessication cracked quartzwacke of facies 6-I (Table 1) at 300 m (Figure 17), representing a change from open-marine carbonate to restricted/lagoonal siliciclastic rocks and evaporite .
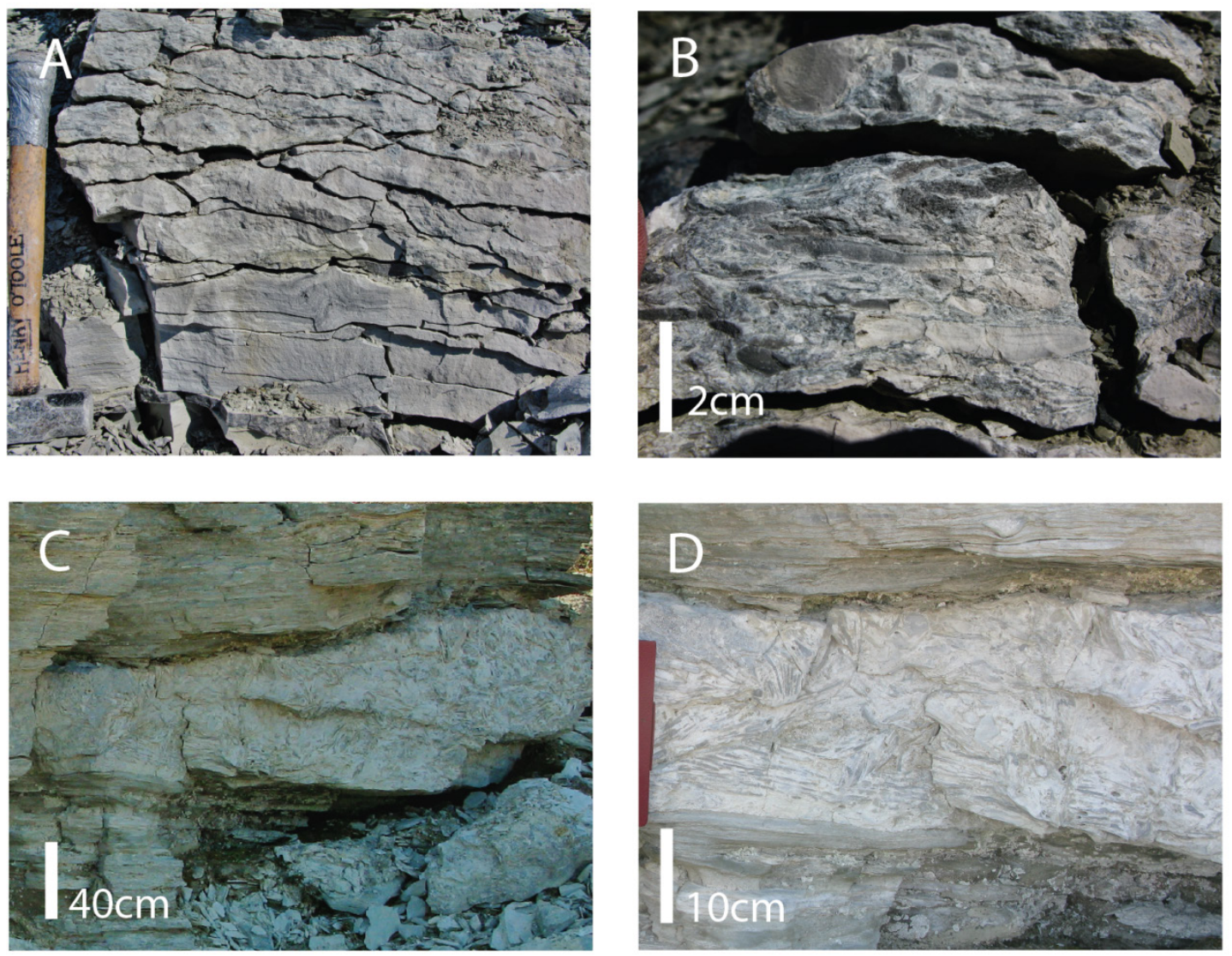

Figure 18: A) Quartz arenite grading upward into framework-supported, pebble conglomerate, which marks the sequence boundary between B5-I and B5-II. Hammer is $\sim 35 \mathrm{~cm}$ tall. B) Close-up of conglomerate in A). C) Framework-supported flat-pebble to cobble breccia scoured into mudstone, a contact interpreted as the boundary between sequences B5-III and B5-IV. D) Close-up of breccia in C). 


\section{Sequence B5-III}

The lower bounding surface of sequence B5-III coincides with the base of the clastic-carbonate member. A >80 m-thick section consisting of halite-casted siltstone of facies 6-I, inter-tidal siltstone/claystone and sandstone couplets of facies 6-III and shoreface to foreshore deposits of facies 6-II and 6-IV (Table 1) is interpreted to represent the LST (Figure 17). The MSR occurs above a $\sim 4$-thick quartz arenite unit at $\sim 400 \mathrm{~m}$ (Figure 17), which is interpreted as a beach deposit. The overlying TST includes red, green and dark grey shale of facies 4 and 5 along with stromatolitic limestone of facies 3 which directly overlie the quartz arenite unit described above. The top of the TST is marked by a MFS which lies above a 2 m-thick accumulation of dark shale of facies 4 . This is interpreted to represent the maximum flooding of land surface within this sequence. A close association with red and green, dessication-cracked siltstone/claystone of facies 5 both above and below the dark shale horizon suggests that deep water conditions were short-lived. Above the thin dark shale interval is a 20 m-thick interval of finely laminated and stromatolitic carbonate of facies 3 with minor horizons of finely-laminated, red and green, argillaceous siltstone of facies 5 with desiccation-cracks. These are in turn overlain by a $>10$ m-thick interval of tan grainstone and mudstone of facies 7 with common gutter casts and scours. This facies stacking pattern is interpreted to be the FSST. The upper sequence boundary is exposed at station 11RATJP048 (Figure 5), and is marked by sharp-based bed of frameworksupported, monomictic, flat-pebble to cobble breccia which scours into mudstone 
(Figure 18) and separates shallow to emergent grainstone and mudstone from overlying evaporitic, desiccation-cracked, gypsiferous siltstone/claystone.

\section{Sequence B5-IV}

The lower part of sequence B5-IV consists of a 20 m-thick unit comprising grainstone and dolomitic grainstone of facies 7, thin (5-15 cm-thick), plane-bedded and cross-stratified quartz arenite of facies 6-II, thinly laminated siltsone of facies 5 and minor gypsiferous siltstone of facies 1-I. Desiccation cracks and scours are common throughout indicating shallow to emergent conditions. This interval is overlain by a $\sim 45$ m-thick accumulation of gypsiferous siltstones of facies 1-I, nodular and chicken-wire gypsum/anhydrite, thin beds of grass-like selenite of facies 1-III, $10 \mathrm{~cm}$-thick beds of ripple cross-stratified gypsarenite, grainstone and mudstone of facies 7 . This facies association is consistent with deposition in an evaporitic mudflat setting (Warren, 1991). This interval is overlain by a $\sim 40 \mathrm{~m}$-thick succession dominated by red siltstone of facies 5 with common desiccation cracks, ripple cross-laminations and interbeds of dolomitic grainstone of facies 7, but evaporite facies are absent. This interval represents similar depositional conditions to underlying evaporitic mudflat facies, and little change in relative sea level is inferred throughout sequence B5-IV. The three units described above comprise the LST. No other obvious systems tracts can be identified in this sequence as the contact between the Kilian and Kuujjua formations, which directly overlies the units described above, coincides with a second-order sequence boundary and may truncate underlying strata considerably. The bounding surface is marked by a sharp-based, oligomictic, framework-supported, cobble conglomerate which is 
interpreted to represent a major erosional unconformity between red and green siltstone and dolomitic grainstone deposited on a mudflat and overlying volcaniclastic sandstones which grade upward into fluvial quartz arenite at the base of the Kuujjua Formation.

\subsection{Discussion:}

Sequence stratigraphic evolution of the Minto Inlet Formation

The depositional environment is interpreted to have varied only slightly during deposition of the Minto Inlet Formation. The lower evaporite member consists primarily of fine-grained clastic material and nodular sulphate with minor carbonate interbeds deposited on an evaporitic mudflat. A minor rise in relative sea level accompanied by clastic starvation allowed for the deposition of the shallow, sub-tidal facies of the carbonate member. The transition to the upper evaporite member is characterized by a minor drop in relative sea level coupled with either an increase in evaporative loss and/or an increase in the level of basin restriction. Small-scale carbonate-evaporite cycles near the top of the Minto Inlet Formation reflect rapid changes in the chemistry of the basin, likely due to frequent inundation by normal salinity water from the open ocean. These are interpreted as saltern evaporites (Warren, 1991). The primary controls on deposition of the Minto Inlet Formation are clastic supply, evaporative loss, and relative sea-level.

Sequence stratigraphic evolution of the Kilian Formation 
Sequences within the Kilian Formation appear to have all formed during two stages of deposition, each a reflection of the predominant tectonic and eustatic drivers affecting sediment accommodation space at the time of deposition.

Stage I

Stage I is recorded in sequences B5-I, B5-II and part of B5-III, which includes the lower 5 members of the Kilian Formation. Stage I comprises three evaporite-carbonate cycles, each 100-200 m thick. The boundaries of these cycles roughly coincide with the onset of the FSST of third-order sequences or, where absent, with sequence stratigraphic boundaries. The lower two evaporite-carbonate cycles described here coincide with transgressive-regressive cycles described by Rainbird (1991), which were attributed to either tectonoeustatic or glacioeustatic controls. In this work, the clastic carbonate member and the base of the tan carbonate member are included in stage I, as they follow the same pattern as the lower two cycles, although the evaporite facies are less well developed. Each of the cycles are characterized by sudden influx of mostly clay and silt into a carbonate-dominated environment. The influx of siliciclastic sediment coincides with a change from sub-tidal to inter-tidal water depths and usually with evaporite deposition. The carbonate intervals in stage I do not show significant variations in depositional depth suggesting that basin subsidence was balanced by carbonate deposition. The depositional environment during stage I is interpreted to be a gently and steadily subsiding carbonate ramp, occasionally inundated by siliciclastic sediment from a nearby source. 
Stage II

Stage II comprises the top of sequence B5-III and B5-IV and includes the upper part of the tan carbonate member as well as the upper evaporite and red shaly carbonate members. This stage, like stage I, is characterized by sudden influx of siliciclastic material into a carbonate-dominated system; however this process does not account for the regression in stage II. The FSST of sequence B5-III is dominated by peritidal limestone and dolostone characterized by desiccation cracks, flat-pebble conglomerate, dewatering structures and gutter casts. This indicates a drop in relative sea level, unaccompanied by an influx of siliciclastic sediment. The upward-shallowing trend which starts in the tan carbonate member persists through the Upper Kilian Formation eventually resulting in emergence and the fluvial deposits of the Kuujjua Formation. Erosional bevelling of the Kuujjua and upper Kilian formations in the Northeast Domain of the Minto Inlier has been interpreted as evidence for differential uplift accompanying associated mantle plume-related crustal doming (Jefferson, 1985; Rainbird, 1991; Rainbird, 1993). This interpretation is consistent with observed shallowing upward trend in the upper Kilian Formation as well as with observed basalt and volcanogenic sandstone interstratified with upper Kilian Formation strata, described in this work and previously by Young (1981), Jefferson (1985) and Rainbird (1991; 1993). The uplift is one plausible driver responsible for the differences between stage I and II.

Source of siliciclastic sediments 
Both the Minto Inlet and Kilian formations host siliciclastic sedimentary rocks, interpreted as lithified terrigenous detritus, transported by rivers, the deposits of which are represented by the overlying Kuujjua Formation and units lower in the Shaler Supergroup. Based on detrital zircon geochronology and paleocurrent directions Rainbird et al. (1992; 1997; 2012) proposed that river systems sourced from the Grenville orogen were responsible for the deposition of these sandstones. The episodic recurrence of the siliciclastic deposits is likely due to the migration of such a river system back and forth across the coastal front. The sediment, once in the basin, was subsequently reworked by marine processes. 


\section{Chapter 3: Mid-Neoproterozoic biogeochemical cycling of sulphur and carbon}

\subsection{Introduction}

Stable Isotope Systematics

Stable isotopes are naturally occurring and non-radio-active variations of a given element. Each contain the same number of protons but differ in their number of neutrons. Stable isotope compositions are usually reported in delta notation, for example;

$$
\delta^{34} S=\left[\frac{\left(S^{34} / S^{32}\right)_{\text {sample }}-\left(S^{34} / S^{32}\right)_{\text {standard }}}{\left(S^{34} / S^{32}\right)_{\text {standard }}}\right] * 1000
$$

Stable isotopes do not decay; therefore their natural abundances are fixed and can be calculated. For instance carbon has two stable isotopes, ${ }^{12} \mathrm{C}$, which makes up $98.8922 \%$ of stable carbon and ${ }^{13} \mathrm{C}$, which makes up only $1.107 \%$ (Rosman and Taylor, 1998). Sulphur has four stable isotopes. In order of natural abundance they are ${ }^{32} \mathrm{~S}(95.018 \%)$,

${ }^{34} \mathrm{~S}(4.215 \%),{ }^{33} \mathrm{~S}(0.750 \%)$ and ${ }^{36} \mathrm{~S}(0.017 \%)$ (Rosman and Taylor, 1998). The actual proportions of these isotopes in a given reservoir vary in natural systems because many biogeochemical reactions favour certain isotopes over others. For example most biological reactions including photosynthesis and bacterial sulphate reduction slightly favour the light isotope (e.g. ${ }^{12} \mathrm{C}$ and ${ }^{32} \mathrm{~S}$ ), that is then preferentially concentrated into the products of those reactions. This is due to a higher vibrational energy in the bonds of light isotopes. Bonds with higher vibrational energy are more easily broken, and those isotopes are therefore preferentially partitioned into the products of reactions 
(Canfield, 2001). This preferential separation of the light and heavy isotopes is referred to as fractionation.

\section{Carbon isotope systematics}

There is very little fractionation between carbon in the dissolved inorganic carbon (DIC) reservoir in seawater and carbonate minerals precipitated in equilibrium with that reservoir (Hayes et al., 1999). Therefore the $\delta^{13} \mathrm{C}_{\text {carb }}$ record has in many instances been equated with $\delta^{13} C_{D I C}$ (e.g. Knoll et al., 1986; Halverson et al., 2010). The intimate association of $\delta^{13} C_{D I C}$ and $\delta^{13} C_{c a r b}$ coupled with the widespread and continuous deposition of carbonate rocks through geologic timescales makes them ideal for constructing secular isotope curves for marine seawater carbonate (see Halverson, 2006). Recently, the potential significance of authigenic carbonate (carbonate produced within the substrate, primarily through the oxidation of organic carbon via the diagenetic reduction of sulphate and iron) has put into question the use of $\delta^{13} C_{\text {carb }}$ as a steadfast indicator of $\delta^{13} C_{D I C}$ (e.g. Schrag et al., 2013). In the absence of authigenic carbonate, fluctuations in $\delta^{13} \mathrm{C}_{\text {carb }}$ are usually interpreted to reflect changes in the fractional burial of carbonate $\left(f_{\text {carb }}\right)$ vs organic carbon $\left(f_{\text {corg }}\right)$, where;

$$
f_{\text {Corg }}=\frac{\text { Flux of organic carbon burial }}{\text { Flux of total carbon burial }}=\left(1-f_{\text {carb }}\right)
$$

Because organic carbon is generally isotopically lighter than $\delta^{13} C_{\text {carb }}$, an increase in $f_{\text {corg }}$ under steady state conditions would result in a positive shift in values of $\delta^{13} C_{D I C}$ and by association $\delta^{13} C_{\text {carb. }}$. Alternatively a decrease in $f_{\text {corg }}$ or an increase in $C_{\text {org }}$ 
remineralisation ( $\mathrm{C}_{\text {org }}$ which is oxidized and subsequently redeposited as carbonate carbon) would be accompanied by a decrease in coeval $\delta^{13} \mathrm{C}_{\text {carb }}$ values.

The build-up and release of large volumes of methane hydrate from sediment substrates also has the potential to greatly alter $\delta^{13} C_{D I C}$ (Bjerrum and Canfield, 2011). Methane is produced in anoxic marine sediment substrates through the metabolism of methanogenic microorgansims via the reaction $\mathrm{CO}_{2}+4 \mathrm{H}_{2} \rightarrow \mathrm{CH}_{4}+2 \mathrm{H}_{2} \mathrm{O}$. Methane, like organic carbon, is typically highly depleted in ${ }^{13} \mathrm{C}$ and thus the storage and release of large volumes of sediment-hosted hydrates can conceivably play an important role on carbon isotope systematics.

\section{Sulphur isotope systematics}

Stable isotopes of sulphur as measured from marine evaporite rocks and from carbonate associated sulphate (CAS) reflect the isotopic composition of the marine seawater sulphate reservoir at the time those rocks were deposited (Ault and Kulp, 1959; Thode et al., 1961; Raab and Spiro, 1991). The isotopic composition of the marine sulphate reservoir is controlled by the fractional burial of sedimentary pyrite $\left(f_{p}\right)$ and sulphate evaporite and by the isotopic composition of the weathering flux ( $\left(\delta^{34} S_{\text {weathering }}\right)$. Under a steady state assumption $f_{p}$ is defined in the following way:

$$
f_{p}=\frac{\left(\delta^{34} S_{e v}-\delta^{34} S_{\text {weathering }}\right)}{\left(\delta^{34} S_{e v}-\delta^{34} S_{p y}\right)}
$$

This relationship is illustrated in Figure 19, where the net fractionation between sulphate and sulphide $\left(\Delta^{34} S_{\text {ev-py }}\right)$ is fixed. 


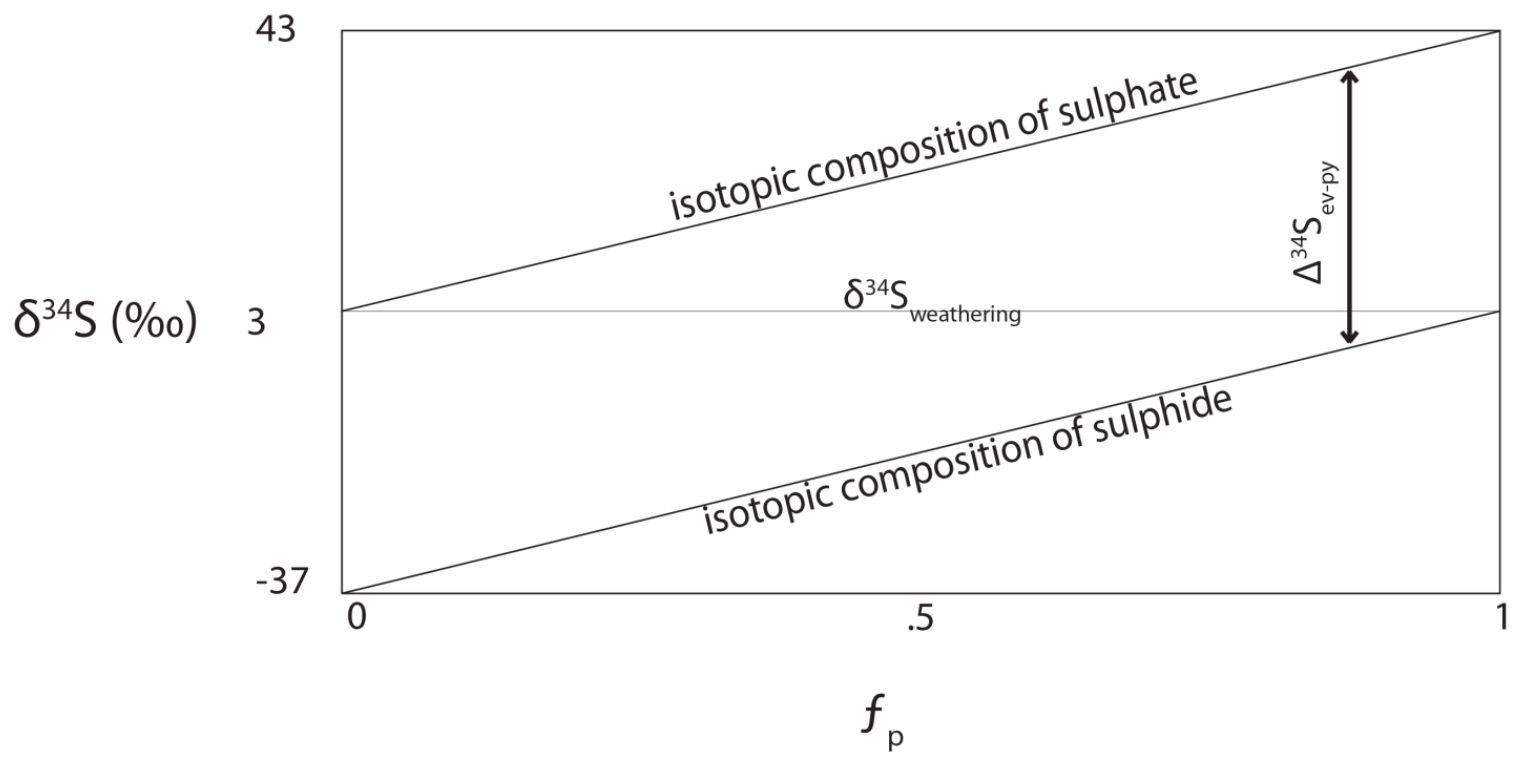

Figure 19: simple sulphur isotope schematic for a closed system in steady state

More recently, the advent of multiple sulphur isotope analysis has provided a new tool for studying Earth history (see Farquhar et al., 2000; Farquhar and Wing, 2003; Johnston et al., 2005b). The application of multiple sulphur isotope geochemistry hinges on the precise measurement of the minor isotopes of sulphur $\left(\mathrm{S}^{33}, \mathrm{~s}^{36}\right)$. In mass dependent systems, $\delta^{33} S$ values are closely related to $\delta^{34} S$, offset by a scaling factor. Mass dependent sulphur isotope data therefore falls on a straight line in $\delta^{33} S$ vs $\delta^{34} S$ space, the slope of this terrestrial fractionation line $\left(\lambda^{33}{ }_{\text {TFL }}\right)$ has been constrained at 0.515 (Farquhar and Wing, 2003). In natural systems however, small but systematic deviations from this relationship are recognized (Johnston, 2011). These small deviations are quantified as $\Delta^{33} \mathrm{~S}$ (different notation than $\Delta^{34} \mathrm{~S}_{\mathrm{ev}-\mathrm{py}}$ ), and are calculated as follows. 


$$
\Delta^{33} S=\delta^{33} S-1000\left[\left(1+\frac{\delta^{34} S}{1000}\right)^{\lambda^{33} \mathrm{TFL}}-1\right]
$$

But a linear definition is also possible, here denoted as $\Delta^{33 \prime} S$ and calculated in the following way:

$$
\Delta^{33 \prime} \mathrm{S}=\delta^{33} \mathrm{~S}-\lambda^{33} \mathrm{TFL}\left(\delta^{34} \mathrm{~S}\right)
$$

During mass dependent fractionation $\Delta^{33} S$ values are generally restricted to $\pm 0.2 \%$ of zero (Farquhar and Wing, 2003).

Coupling of the carbon and sulphur cycles

A general negative correlation of the secular isotope curves for $\delta^{13} C_{\text {carb }}$ and $\delta^{34} S$ has been observed through the Phanerozoic (Garrels and Lerman, 1984) and is thought to be the reflection of the following chemical reaction where sulphate is used as an electron acceptor in the remineralisation of organic carbon.

$$
2 \mathrm{CH}_{2} \mathrm{O}+\mathrm{SO}_{4}{ }^{2-} \rightarrow \mathrm{H}_{2} \mathrm{~S}+2 \mathrm{HCO}_{3}^{-}
$$

Less frequent observations of positive coupling of $\delta^{13} \mathrm{C}_{\mathrm{carb}}$ and $\delta^{34} \mathrm{~S}$ is likely the result of similar sizes and residence times of the seawater reservoirs of DIC and sulphate (e.g. Hurtgen et al., 2009).

Stable isotope geochemistry paired with experimental microbiology and biogeochemical modelling has allowed for a much better understanding of the cycling of bio-essential elements like carbon and sulphur through the geologic past (Berner, 1989; Farquhar et al., 2000; Bartley and Kah, 2004; Johnston, 2011). Both the cycles of carbon 
and sulphur can be broken down into a series of geologically important reservoirs with associated mass fluxes between them. These reservoirs include the lithosphere, oceans and mantle (Figure 20). Sulphur and carbon migrate through the Earth's surface reservoirs by a combination of biological, geological and chemical processes. The fluxes between these reservoirs are thought to be driven, over geologically significant time periods, by a combination of large-scale mechanisms such as continental weathering and ocean redox. Because the stable isotopes of sulphur and carbon are systematically partitioned into these reservoirs they provide a unique tool for assessing the evolution of the biogeochemical cycling of carbon and sulphur.

Minimal fractionation observed between the marine sulphate reservoir and sulphate minerals precipitated in equilibrium with that reservoir validate the use of $\delta^{34} S$ from marine evaporites $\left(\delta^{34} \mathrm{~S}_{\mathrm{evap}}\right)$ as a proxy for $\delta^{34} \mathrm{~S}$ of the marine sulphate reservoir $\left(\delta^{34} S_{M S R}\right)$ (Ault and Kulp, 1959; Thode et al., 1961; Raab and Spiro, 1991). However, the poor distribution of evaporites through the Precambrian makes them less than ideal for constructing secular curves for global seawater sulphate. In recent years, a new analytical technique has been developed, which allows for the isotopic measurement of CAS. Carbonate associated sulphate refers to sulphate ions bound within the framework of carbonate minerals, predominantly as $\mathrm{SO}_{4}$ ions substituting for $\mathrm{CO}_{3}$ ions, despite differences in size and structure, within a crystal lattice (Burdett et al., 1989; Staudt and Schoonen, 1995; Gellatly and Lyons, 2005). Carbonate rocks are both widespread and deposited under normal marine conditions; furthermore, the isotopic composition of CAS has been shown to closely reflect that of seawater sulphate (Burdett et al., 1989; 
Strauss, 1997; Kampschulte et al., 2001; Lyons et al., 2004; Marenco et al., 2008), making CAS analysis ideal for constructing secular S-isotope curves for seawater sulphate (e.g. Hurtgen et al., 2005; Hurtgen et al., 2002; Kah et al., 2004).

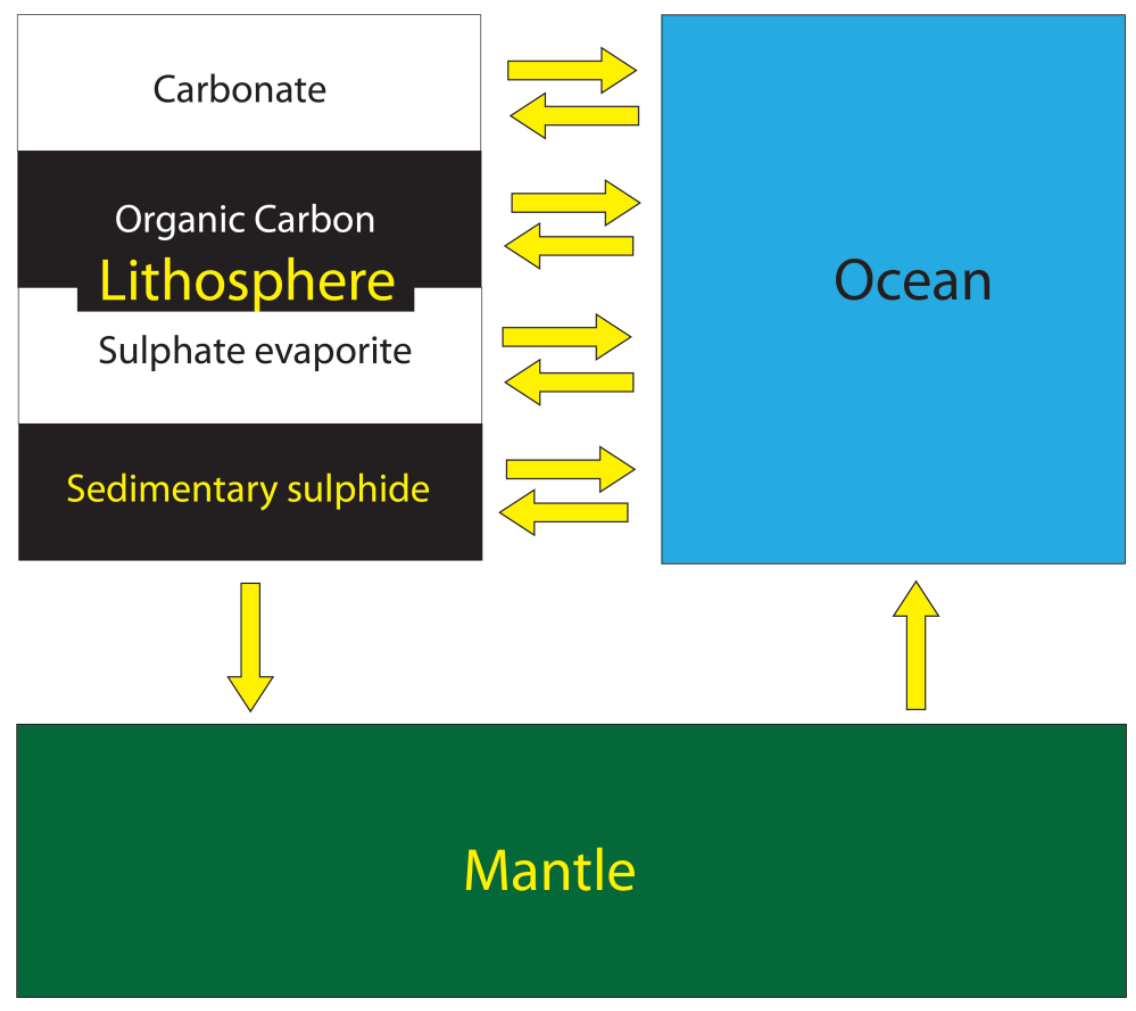

Figure 20: Representation of the sulphur and carbon cycles highlighting the reduced (black) and oxidized (white) reservoirs in the lithosphere, after Berner (1987).

\subsection{Current understanding of Neoproterozoic cycling of carbon and sulphur}

The carbon isotope record through the late Mesoproterozoic and early Neoproterozoic is characterized by an initial stepwise increase in mean $\delta^{13} C_{\text {carb }}$ values from $\sim \%$ to $~ 5 \%$, which is followed through the mid to late Neoproterozoic by a series of very large (10-15\%) negative excursions (Figure 21). There are at least 4 distinct and 
globally correlated large negative carbon isotope excursions, that occurred during the Neoproterozoic. From oldest to youngest these are termed the Bitter Springs, Islay, Trezona and Shuram-Wonoka anomalies (Burns and Matter, 1993; Pell et al., 1993; Brasier and Shields, 2000; Hill and Walter, 2000; McKirdy et al., 2001).

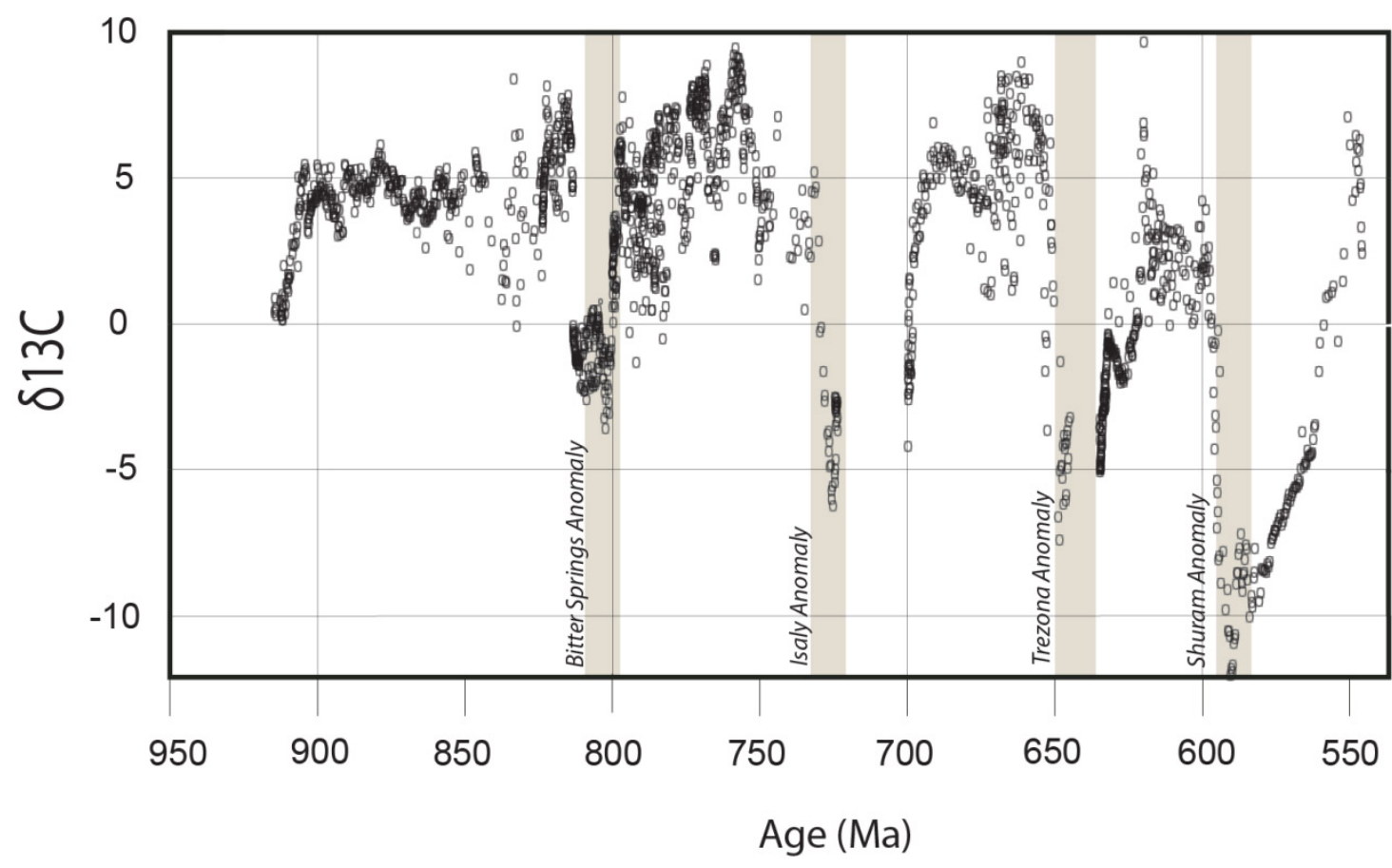

Figure 21: Stable isotope record of $\delta^{13} \mathrm{C}_{\text {carb }}$ through the Neoproterozoic. Data compiled from Halverson et al. (2006), Halverson et al. (2005) and Fike et al. (2006).

The genesis of negative carbon isotope excursions of this magnitude is presently debated. Competing theories include: oxidation of huge amounts of organic carbon (Kump et al., 2011); release and subsequent oxidation of methane from sedimenthosted clathrates (Bjerrum and Canfield, 2011); exaggerated variability due to low DIC concentrations (Rothman et al., 2003; Bartley and Kah, 2004); and the formation of isotopically light authigenic carbonate (Bristow and Kennedy, 2008; Schrag et al., 2013). 
The first three mechanisms require significant changes to the oxidant budget of the atmosphere and ocean. The fourth requires an explanation for the widespread and synchronous formation of authigenic carbonates of similar isotopic composition, independent of lithology. Aside from the genesis of negative excursions, any model including Neoproterozoic carbon isotope systematics must also explain the $\sim 5 \%$ enrichment that is recorded for the $\sim 100$ million years prior to the Bitter Springs excursion-the earliest of the Neoproterozoic negative carbon isotope stages (Halverson et al., 2010). Schrag et al. (2013) suggested that the enrichment can be maintained by a consistent burial of isotopically light authigenic carbonate, thereby forcing the DIC to heavier values. Bartley and Kah (2004) use a non- steady-state model that requires a $50 \%$ increase in $f_{\text {corg }}$ to explain the $\sim 5 \%$ onrichment in $\delta^{13} C_{\text {carb. }}$. This would necessarily be associated with a significant increase in atmospheric oxygen concentrations, which Schrag et al. (2013) claim there is no evidence for.

Through the Mesoproterozoic and the early Neoproterozoic, $\delta^{34} \mathrm{~S}_{\mathrm{py}}$ values remained elevated, 3\%o (Canfield, 2004), a value similar to estimates of the isotopic composition of the continental weathering flux $\left(\delta^{34} S_{\text {weathering }}\right.$ ) (eg. 3-8\%; Garrels and Lerman, 1981; Holser et al., 1988; Hurtgen et al., 2006). The small fractionation between $\delta^{34} S_{\text {weathering }}$ and $\delta^{34} S_{p y}$ suggests that $f_{p}$ was near 1 , according to equation 3 . The high $f_{p}$ is thought to be the result of low sulphate concentrations in the oceans making the precipitation of sulphate evaporites highly unlikely (Canfield, 2004). These conditions are considered to have persisted until the Ediacaran period at which point a large increase in $\Delta^{34} \mathrm{~S}_{\mathrm{ev}-\mathrm{py}}$ is thought to indicate a major shift in the sulphur cycle (Halverson 
and Hurtgen, 2007). However, the formation of early- to mid-Neoproterozoic evaporite deposits described in this study and elsewhere does not fit with the current understanding of the evolution of the sulphur cycle.

In order to resolve this discrepancy, samples of sulphate and carbonate collected from both the Minto Inlet and Kilian formations were analyzed for the stable isotopes of sulphur and carbon. These data provide a unique opportunity to model and interpret the biogeochemical cycling of sulphur and carbon during deposition and may help resolve some of the enigmatic isotope trends observed during this time.

\subsection{Samples and Analytical Methods}

A total of 67 samples of gypsum/anhydrite were collected from the Minto Inlet Formation and analyzed for multiple sulphur isotopes. Another 87 samples were collected from the Kilian Formation for analysis of carbon and sulphur isotopes. Samples included both sulphate evaporites and carbonate rocks and were collected at stratigraphic intervals of approximately $3 \mathrm{~m}$, wherever possible.

Samples of sulphate from the Minto Inlet Formation were powdered by micro drilling and sulphur was extracted and precipitated as silver sulphide by the method of Thode et al. (1961; Appendix 2). The silver sulphide samples were then converted to sulphur-hexafluoride by the method of Thode and Rees (1971; Appendix 2) before being analyzed at McGill University on a Thermo Scientific Mat 253 mass spectrometer fitted with a dual inlet to determine the isotopic composition of the major $\left(\delta^{34} \mathrm{~S}\right)$ and minor $\left(\delta^{33} S, \delta^{36} S\right)$ isotopes of sulphur. 
Samples collected for carbon isotope analysis of the Kilian Formation predominantly come from limestone, with a few dolostone samples. $\delta^{13} \mathrm{C}_{\text {carb }}$ measurements were conducted at the G.G. Hatch laboratory at University of Ottawa. Samples were trimmed then micro-drilled using a Dremel tool, fitted with a diamond bit. Cross contamination was mitigated by thoroughly rinsing the drill bit between samples with distilled water and ethanol. Approximately 1-2 mg of powder was weighed and placed in a small tin capsule. The sample was then combusted to convert the carbon to $\mathrm{CO}_{2(\mathrm{~g})}$. The gas was analyzed on a continuous flow DeltaPlus Advantage Isotope ratio mass spectrometer coupled with a ConFlo II interface.

Samples of the Kilian Formation for $\delta^{34} S_{\text {ev }}$ analysis were collected from bedded or nodular gypsum/anhydrite. $\delta^{34} \mathrm{~S}_{\mathrm{ev}}$ isotope analysis was conducted at the G. G. Hatch laboratory at University of Ottawa. Samples of gypsum and anhydrite for sulphur isotope analysis were micro-drilled after removing weathered surfaces and veins. Approximately $2 \mathrm{mg}$ of powder was weighed and placed in a tin capsule along with approximately $4 \mathrm{mg}$ of tungsten oxide, which acts as an oxidizer for combustion. The sulphate in the sample was combusted to form $\mathrm{SO}_{2(\mathrm{~g})}$. The $\mathrm{SO}_{2}$ was passed through a gas chromatograph and fed by continuous flow to the mass spectrometer. The isotopic composition was determined by a DeltaPlus XP mass spectrometer.

Carbonate associated sulphate analyses were conducted on samples of carbonate to fill stratigraphic gaps in the $\delta^{34} \mathrm{~S}_{\mathrm{ev}}$ curve. Sample preparation and isotopic analyses were conducted at the stable isotope laboratories at McGill University. The CAS analytical 
procedure, outlined in detail in Appendix 2, is based largely on that of Burdett et al. (1989) modified by Kampschulte et al. (2001) and Marenco et al. (2008).

\subsection{Results}


Table 3: Multiple sulphur isotope composition of Minto Inlet Formation samples

\begin{tabular}{|c|c|c|c|c|c|c|c|}
\hline Sample number & Section & $\begin{array}{c}\text { Stratigraphic } \\
\text { Height }(\mathrm{m})\end{array}$ & $\begin{array}{l}\delta^{34} S_{e v}(\% o \\
C D T)\end{array}$ & $\Delta^{33} S_{e v}(\% o)$ & $\Delta^{36} S_{e v}(\% o)$ & $\Delta^{33} S_{\text {ev }}^{\prime}(\%)$ & $\Delta^{36} S_{\text {ev }}^{\prime}(\% o)$ \\
\hline 10RATJP048A05 & 10DTS1 & 124.2 & 16.17 & 0.022 & -0.027 & -0.003 & 0.184 \\
\hline 10RATJP048A07 & 10DTS1 & 130.4 & 15.91 & 0.024 & -0.236 & 0.019 & 0.162 \\
\hline 10RATJP048A08 & 10DTS1 & 133.4 & 15.62 & 0.020 & -0.274 & -0.027 & 0.119 \\
\hline 10RATJP048A11 & 10DTS1 & 142.4 & 15.44 & 0.016 & -0.264 & -0.008 & 0.154 \\
\hline 10RATJP048A13 & 10DTS1 & 148.4 & 16.17 & 0.014 & -0.373 & -0.009 & 0.073 \\
\hline 10RATJP048A16 & 10DTS1 & 154.9 & 16.32 & 0.007 & -0.240 & -0.001 & 0.155 \\
\hline 10RATJP048A17 & 10DTS1 & 157.9 & 16.22 & 0.011 & -0.216 & -0.011 & 0.200 \\
\hline 10RATJP048A18 & 10DTS1 & 184.7 & 15.71 & -0.008 & -0.301 & -0.030 & -0.214 \\
\hline 10RATJP050A01 & 10DTS2 & 213.2 & 17.39 & 0.034 & -0.248 & -0.012 & 0.265 \\
\hline 10RATJP050A02 & 10DTS2 & 215 & 17.36 & 0.056 & -0.269 & -0.006 & 0.252 \\
\hline 10RATJP050A03 & 10DTS2 & 216 & 17.97 & 0.013 & -0.337 & -0.032 & 0.040 \\
\hline 10RATJP050A04 & 10DTS2 & 216.5 & 17.25 & 0.029 & -0.273 & 0.001 & -0.094 \\
\hline 10RATJP050A05 & 10DTS2 & 218.75 & 17.36 & 0.028 & -0.358 & -0.002 & 0.195 \\
\hline 10RATJP050A06 & 10DTS2 & 221.55 & 16.95 & 0.035 & -0.260 & 0.003 & 0.083 \\
\hline 10RATJP050A07 & 10DTS2 & 224.4 & 17.75 & 0.028 & -0.247 & -0.033 & 0.068 \\
\hline 10RATJP050A08 & 10DTS2 & 227.1 & 17.44 & 0.008 & -0.648 & -0.015 & 0.171 \\
\hline 10RATJP050A09 & 10DTS2 & 229.4 & 17.54 & 0.026 & -0.173 & -0.014 & 0.066 \\
\hline 10RATJP050A10 & 10DTS2 & 233.2 & 17.76 & 0.033 & -0.195 & -0.020 & -0.109 \\
\hline 10RATJP050A11 & 10DTS2 & 234.5 & 19.36 & 0.014 & -0.474 & -0.030 & -0.111 \\
\hline 10RATJP050A12 & 10DTS2 & 239.1 & 17.61 & 0.040 & -0.535 & -0.043 & 0.113 \\
\hline 10RATJP050A13 & 10DTS2 & 240.75 & 17.54 & 0.036 & -0.243 & -0.023 & 0.246 \\
\hline 10RATJP050A14 & 10DTS2 & 243.2 & 17.19 & 0.040 & -0.341 & -0.021 & 0.112 \\
\hline 10RATJP050A15 & 10DTS2 & 245.1 & 17.54 & 0.005 & -0.370 & -0.028 & 0.115 \\
\hline 10RATJP050A16 & 10DTS2 & 246.2 & 16.82 & 0.020 & -0.239 & -0.020 & 0.210 \\
\hline 10RATJP050A16 & 10DTS2 & 246.2 & 16.78 & 0.021 & -0.342 & -0.011 & 0.358 \\
\hline 10RATJP050A17 & 10DTS2 & 246.6 & 17.40 & 0.018 & -0.542 & -0.007 & 0.140 \\
\hline 10RATJP050A18 & 10DTS2 & 247.3 & 16.89 & 0.005 & -0.524 & -0.010 & 0.091 \\
\hline 10RATJP050A19 & 10DTS2 & 248.8 & 16.05 & -0.011 & -0.267 & -0.014 & 0.094 \\
\hline
\end{tabular}


Table 3 (continued)

\begin{tabular}{|c|c|c|c|c|c|c|c|}
\hline Sample number & Section & $\begin{array}{c}\text { Stratigraphic } \\
\text { Height }(\mathrm{m})\end{array}$ & $\begin{array}{l}\delta^{34} \mathrm{~S}_{\mathrm{ev}}(\% \circ \\
\mathrm{CDT})\end{array}$ & $\Delta^{33} S_{e v}(\%)$ & $\Delta^{36} S_{\mathrm{ev}}(\%)$ & $\Delta^{33} S_{\text {ev }}^{\prime}$ (\%o) & $\Delta^{36} \mathrm{~S}_{\mathrm{ev}}^{\prime}(\% \circ)$ \\
\hline 10RATJP050A20 & 10DTS2 & 249.7 & 16.75 & 0.012 & -0.162 & -0.018 & 0.012 \\
\hline 10RATJP050A21 & 10DTS2 & 251.25 & 16.62 & 0.013 & -0.290 & -0.026 & 0.151 \\
\hline 10RATJP050A22 & 10DTS2 & 254.7 & 17.14 & 0.008 & -0.308 & -0.022 & 0.171 \\
\hline 10RATJP050A23 & 10DTS2 & 257.5 & 18.22 & 0.021 & -0.256 & -0.039 & 0.067 \\
\hline 11RATJP157A01 & 11JPS8 & 212 & 15.98 & 0.065 & 2.276 & -0.033 & 0.037 \\
\hline 11RATJP157A02 & 11JPS8 & 217.8 & 15.64 & 0.017 & 0.180 & -0.040 & 0.016 \\
\hline 11RATJP157A03 & 11JPS8 & 222.3 & 15.39 & 0.024 & -0.523 & -0.009 & 0.017 \\
\hline 11RATJP157A04 & 11JPS8 & 238.8 & 16.83 & 0.021 & -0.399 & -0.002 & -0.021 \\
\hline 11RATJP157A05 & 11JPS8 & 244.7 & 16.45 & 0.008 & -0.639 & -0.025 & 0.103 \\
\hline 11RATJP157A06 & 11JPS8 & 250.1 & 15.84 & 0.031 & -0.415 & 0.086 & 0.197 \\
\hline 11RATJP157A07 & 11JPS8 & 256.5 & 16.35 & 0.025 & -0.445 & 0.024 & 0.112 \\
\hline 11RATJP157A08 & 11JPS8 & 262.2 & 16.24 & 0.016 & -0.485 & -0.013 & 0.166 \\
\hline 11RATJP157A09 & 11JPS8 & 271.2 & 17.05 & -0.021 & -0.368 & 0.007 & 1.053 \\
\hline 11RATJP157A10 & 11JPS8 & 273.2 & 16.67 & 0.099 & -0.233 & -0.002 & 0.005 \\
\hline 11RATJP157A11 & 11JPS8 & 205.2 & 15.17 & 0.005 & -0.027 & 0.087 & 0.111 \\
\hline 11RATJP157A12 & 11JPS8 & 208 & 15.52 & 0.008 & -0.506 & 0.004 & 0.813 \\
\hline 11RATJP157A13 & 11JPS8 & 216.5 & 16.42 & 0.011 & 0.653 & -0.039 & 0.171 \\
\hline 11RATJP157A14 & 11JPS8 & 241.8 & 16.52 & -0.036 & -0.641 & -0.016 & 0.642 \\
\hline 11RATJP157A15 & 11JPS8 & 247.2 & 16.34 & 0.067 & 1.124 & -0.026 & 0.061 \\
\hline 11RATJP157A16 & 11JPS8 & 259.6 & 16.23 & 0.023 & -0.320 & -0.054 & 0.278 \\
\hline 11RATJP157A17 & 11JPS8 & 265.9 & 16.51 & 0.030 & -0.298 & -0.044 & 0.042 \\
\hline GNME 06-03 193.85 & GNME 06-03 & 70.65 & 19.41 & 0.007 & -0.345 & -0.051 & 0.061 \\
\hline GNME 06-03 212.15 & GNME 06-03 & 52.35 & 16.40 & 0.017 & 0.248 & 0.033 & 2.654 \\
\hline GNME 06-03 215 & GNME 06-03 & 49.5 & 16.66 & 0.008 & -0.342 & -0.013 & 0.545 \\
\hline GNME 06-03 225.9 & GNME 06-03 & 38.6 & 22.71 & 0.009 & -0.389 & -0.006 & -0.167 \\
\hline GNME 06-03 229 & GNME 06-03 & 35.5 & 22.13 & 0.017 & -0.598 & -0.014 & 0.011 \\
\hline GNME 06-03 259.3 & GNME 06-03 & 22.7 & 20.11 & -0.001 & -0.485 & -0.026 & -0.244 \\
\hline
\end{tabular}


Table 3 (continued)

\begin{tabular}{llclllll}
\hline Sample number & Section & $\begin{array}{c}\text { Stratigraphic } \\
\text { Height }(\mathrm{m})\end{array}$ & $\begin{array}{l}\delta^{34} \mathrm{~S}_{\mathrm{ev}}(\% \mathrm{\%}) \\
\mathrm{CDT})\end{array}$ & $\Delta^{33} \mathrm{~S}_{\mathrm{ev}}(\% \mathrm{o})$ & $\Delta^{36} \mathrm{~S}_{\mathrm{ev}}(\% \mathrm{o})$ & $\Delta^{33} \mathrm{~S}_{\mathrm{ev}}(\% \mathrm{o})$ & $\Delta^{36} \mathrm{~S}_{\mathrm{ev}}(\% \mathrm{o})$ \\
\hline GNME 06-03 45.6 & GNME 06-03 & 148.9 & 16.23 & 0.000 & -0.350 & 0.000 & -0.043 \\
GNME 06-03 51.1 & GNME 06-03 & 143.4 & 16.28 & -0.008 & -0.373 & -0.008 & -0.053 \\
GNME 06-03 54.1 & GNME 06-03 & 140.4 & 15.90 & 0.022 & -0.358 & -0.016 & -0.097 \\
GNME 06-03 58 & GNME 06-03 & 136.5 & 16.51 & 0.032 & -0.419 & -0.057 & 0.051 \\
GNME 06-03 60 & GNME 06-03 & 134.5 & 16.23 & 0.007 & -0.285 & 0.064 & 0.171 \\
GNME 06-03 63.05 & GNME 06-03 & 131.45 & 15.74 & 0.116 & -0.172 & -0.024 & 0.321 \\
GNME 06-03 70 & GNME 06-03 & 124.5 & 15.60 & 0.055 & -0.252 & -0.022 & -0.145 \\
GNME 06-03 75.9 & GNME 06-03 & 118.6 & 15.75 & 0.018 & -0.204 & -0.022 & 1.048 \\
GNME 06-03 80.9 & GNME 06-03 & 113.6 & 16.40 & 0.040 & 0.660 & -0.070 & -0.242 \\
GNME 06-03 84 & GNME 06-03 & 110.5 & 16.08 & 0.030 & -0.377 & 0.034 & 1.516 \\
GNME 06-03 86.95 & GNME 06-03 & 108.15 & 15.41 & 0.117 & -0.246 & -0.010 & 0.068 \\
GNME 06-03 89.95 & GNME 06-03 & 104.55 & 15.71 & 0.035 & 0.445 & -0.004 & 0.100 \\
\hline
\end{tabular}


Table 4: Isotopic composition of Kilian Formation samples

\begin{tabular}{|c|c|c|c|c|c|c|}
\hline Sample number & Section & Stratigraphic Height (m) & $\delta^{34} S_{\text {evap }}(\% \circ C D T)$ & $\delta^{34} S_{\text {CAS }}(\% \circ C D T)$ & $\delta^{13} C_{\text {carb }}(\% \circ$ VPDB $)$ & $\delta^{18} \mathrm{O}_{\text {carb }}(\% \circ \mathrm{VPDB})$ \\
\hline 11RATJP43A08 & 11JPS1 & 403.4 & & & 0.79 & -8.90 \\
\hline 11RATJP43A09 & 11JPS1 & 407.9 & & 26.74 & -0.46 & -10.02 \\
\hline 11RATJP43A10 & 11JPS1 & 410.4 & & 33.29 & -0.50 & -10.34 \\
\hline 11RATJP43A16 & 11JPS1 & 430.4 & & 27.28 & -2.93 & -11.26 \\
\hline 11RATJP43A18 & 11JPS1 & 436.4 & & 29.09 & -2.74 & -7.96 \\
\hline 11RATJP43A18 duplicate & 11JPS1 & 436.4 & & & -2.72 & -7.96 \\
\hline 11RATJP75A01 & 11JPS2 & 0.0 & 29.61 & & & \\
\hline 11RATJP75A02 & 11JPS2 & 4.0 & 29.11 & & & \\
\hline 11RATJP75A03 & 11JPS2 & 6.2 & 30.09 & & & \\
\hline 11RATJP75A04 & 11JPS2 & 12.5 & 32.93 & & & \\
\hline 11RATJP75A05 & 11JPS2 & 15.5 & 33.47 & & & \\
\hline 11RATJP75A05 duplicate & 11JPS2 & 15.5 & 33.43 & & & \\
\hline 11RATJP75A06 & 11JPS2 & 17.6 & 33.01 & & & \\
\hline 11RATJP75A07 & 11JPS2 & 20.5 & & & 2.86 & -6.26 \\
\hline 11RATJP75A08 & 11JPS2 & 21.7 & 34.91 & & & \\
\hline 11RATJP75A09 & 11JPS2 & 25.0 & & & 3.10 & -6.69 \\
\hline 11RATJP75A10 & 11JPS2 & 28.1 & 35.90 & & 1.44 & -13.75 \\
\hline 11RATJP75A11 & 11JPS2 & 34.7 & & & 3.17 & -5.50 \\
\hline 11RATJP75A12 & 11JPS2 & 37.0 & & & 3.58 & -6.19 \\
\hline 11RATJP75A13 & 11JPS2 & 40.1 & & & 4.76 & -6.16 \\
\hline 11RATJP75A14 & 11JPS2 & 43.7 & & & 3.60 & -5.91 \\
\hline 11RATJP75A15 & 11JPS2 & 76.0 & & & 4.80 & -6.22 \\
\hline 11RATJP75A16 & 11JPS2 & 135.0 & 32.56 & & & \\
\hline
\end{tabular}


Table 4 (continued)

\begin{tabular}{|c|c|c|c|c|c|c|}
\hline Sample number & Section & Stratigraphic Height (m) & $\delta^{34} S_{\text {evap }}(\% o C D T)$ & $\delta^{34} S_{\text {CAS }}(\% \circ C D T)$ & $\delta^{13} C_{\text {carb }}$ (\%o VPDB) & $\delta^{18} \mathrm{O}_{\text {carb }}(\% \circ \mathrm{VPDB})$ \\
\hline 11RATJP75A17 & 11JPS2 & 137.5 & 31.72 & & & \\
\hline 11RATJP75A18 & 11JPS2 & 15.3 & & & 1.63 & -5.35 \\
\hline 11RATJP75A18 duplicate & 11JPS2 & 15.3 & & & 1.63 & -5.34 \\
\hline 11RATJP75A19 & 11JPS2 & 24.9 & & & 3.11 & -6.58 \\
\hline 11RATJP75A20 & 11JPS2 & 49.5 & & & 5.61 & -7.79 \\
\hline 11RATJP75A21 & 11JPS2 & 57.3 & & 36.25 & 5.49 & -6.12 \\
\hline 11RATJP75A22 & 11JPS2 & 65.0 & & 38.99 & 6.06 & -6.50 \\
\hline 11RATJP75A23 & 11JPS2 & 74.0 & & 42.61 & 3.88 & -7.85 \\
\hline 11RATJP75A24 & 11JPS2 & 83.5 & & 34.03 & 3.61 & -5.89 \\
\hline 11RATJP75A25 & 11JPS2 & 97.1 & & & 4.5 & -5.22 \\
\hline 11RATJP75A26 & 11JPS2 & 103.3 & & 36.36 & 1.85 & -11.26 \\
\hline 11RATJP75A27 & 11JPS2 & 109.0 & & & 1.98 & -9.67 \\
\hline 11RATJP75A28 & 11JPS2 & 112.5 & & 28.45 & 4.59 & -7.68 \\
\hline 11RATJP75A28 duplicate & 11JPS2 & 112.5 & & & 4.61 & -7.66 \\
\hline 11RATJP75A29 & 11JPS2 & 115.6 & & 34.03 & 6.86 & -5.80 \\
\hline 11RATJP75A30 & 11JPS2 & 171.3 & & & 3.81 & -7.65 \\
\hline 11RATJP75A31 & 11JPS2 & 176.7 & & & 1.69 & -7.43 \\
\hline 11RATJP84A01 & 11JPS3 & 200.0 & & 34.45 & 3.71 & -7.78 \\
\hline 11RATJP84A02 & 11JPS3 & 203.0 & & 29.40 & 5.50 & -7.69 \\
\hline 11RATJP84A02 duplicate & 11JPS3 & 203.0 & & 31.46 & & \\
\hline 11RATJP84A03 & 11JPS3 & 206.8 & & & 2.69 & -5.89 \\
\hline 11RATJP84A04 & 11JPS3 & 211.3 & & 36.83 & 3.27 & -8.35 \\
\hline 11RATJP84A05 & 11JPS3 & 214.3 & & 35.44 & 4.86 & -5.61 \\
\hline
\end{tabular}


Table 4 (continued)

\begin{tabular}{|c|c|c|c|c|c|c|}
\hline Sample number & section & Stratigraphic Height (m) & $\delta^{34} S_{\text {evap }}(\% \circ C D T)$ & $\delta^{34} S_{\text {CAS }}(\% \circ C D T)$ & $\delta^{13} C_{\text {carb }}(\%$ VPDB) & $\delta^{18} \mathrm{O}_{\text {carb }}(\%$ VPDB) \\
\hline 11RATJP84A06 & 11JPS3 & 220.3 & & & 4.93 & -5.42 \\
\hline 11RATJP84A07 & 11JPS3 & 222.9 & & 38.80 & 4.79 & -4.98 \\
\hline 11RATJP84A07 duplicate & 11JPS3 & 222.9 & & & 4.78 & -4.99 \\
\hline 11RATJP84A08 & 11JPS3 & 226.5 & & 32.40 & 4.03 & -8.96 \\
\hline 11RATJP84A09 & 11JPS3 & 232.5 & & & 2.73 & -8.58 \\
\hline 11RATJP84A10 & 11JPS3 & 235.3 & & 36.34 & 0.64 & -9.57 \\
\hline 11RATJP84A11 & 11JPS3 & 238.3 & & 34.25 & 0.96 & -13.26 \\
\hline 11RATJP84A12 & 11JPS3 & 241.5 & & 24.98 & 1.9 & -8.51 \\
\hline 11RATJP84A13 & 11JPS3 & 244.5 & & 31.37 & 4.6 & -7.21 \\
\hline 11RATJP84A14 & 11JPS3 & 250.5 & & & 0.53 & -8.8 \\
\hline 11RATJP84A15 & 11JPS3 & 253.5 & & 20.51 & 2.71 & -8.03 \\
\hline 11RATJP84A16 & 11JPS3 & 253.5 & & 29.82 & & \\
\hline 11RATJP85A01 & 11JPS4 & 492.0 & & & -4.31 & -9.72 \\
\hline 11RATJP85A02 & 11JPS4 & 494.2 & & 21.67 & -4.26 & -9.46 \\
\hline 11RATJP85A02 duplicate & 11JPS4 & 494.2 & & & -4.28 & -9.49 \\
\hline 11RATJP85A03 & 11JPS4 & 497.2 & & & -2.78 & -9.48 \\
\hline 11RATJP85A04 & 11JPS4 & 499.4 & & 18.85 & -4.32 & -10.14 \\
\hline 11RATJP85A05 & 11JPS4 & 502.8 & 19.00 & & & \\
\hline 11RATJP85A06 & 11JPS4 & 503.2 & & 20.85 & -3.76 & -9.93 \\
\hline 11RATJP85A07 & 11JPS4 & 506.8 & & & -3.65 & -7.18 \\
\hline 11RATJP85A08 & 11JPS4 & 510.7 & & 17.34 & -2.85 & -4.24 \\
\hline 11RATJP85A09 & 11JPS4 & 512.6 & & 21.16 & -2.31 & -4.00 \\
\hline 11RATJP85A10 & 11JPS4 & 513.6 & 19.96 & & & \\
\hline
\end{tabular}


Table 4 (continued)

\begin{tabular}{|c|c|c|c|c|c|c|}
\hline Sample number & section & Stratigraphic Height (m) & $\delta^{34} S_{\text {evap }}(\% \circ C D T)$ & $\delta^{34} S_{\text {CAS }}(\% \circ C D T)$ & $\delta^{13} C_{\text {carb }}$ (\%o VPDB) & $\delta^{18} O_{\text {carb }}(\% \circ$ VPDB $)$ \\
\hline 11RATJP85A11 & 11JPS4 & 515.3 & & 36.64 & -1.93 & -4.66 \\
\hline 11RATJP85A12 & 11JPS4 & 519.7 & 20.34 & & & \\
\hline 11RATJP85A13 & 11JPS4 & 520.3 & 18.93 & & & \\
\hline 11RATJP85A13 duplicate & 11JPS4 & 520.3 & 18.92 & & & \\
\hline 11RATJP85A14 & 11JPS4 & 521.6 & 19.76 & & & \\
\hline 11RATJP85A15 & 11JPS4 & 524.6 & 20.82 & & -2.10 & -5.25 \\
\hline 11RATJP85A16 & 11JPS4 & 526.9 & 21.95 & & & \\
\hline 11RATJP85A17 & 11JPS4 & 528.3 & 21.92 & & -1.64 & -13.97 \\
\hline 11RATJP85A18 & 11JPS4 & 529.4 & 21.01 & & -1.8 & -6.67 \\
\hline 11RATJP85A18 duplicate & 11JPS4 & 529.4 & & & -1.78 & -6.89 \\
\hline 11RATJP85A19 & 11JPS4 & 532.4 & 21.48 & & -1.34 & -5.85 \\
\hline 11RATJP85A20 & 11JPS4 & 538.2 & 18.74 & & & \\
\hline 11RATJP85A21 & 11JPS4 & 542.1 & 18.16 & & -1.42 & -5.47 \\
\hline 11RATJP85A23 & 11JPS4 & 546.2 & 17.62 & & -1.61 & -4.91 \\
\hline 11RATJP85A24 & 11JPS4 & 548.3 & 18.19 & & -1.32 & -7.10 \\
\hline 11RATJP85A24 duplicate & 11JPS4 & 548.3 & 18.35 & & & \\
\hline 11RATJP85A25 & 11JPS4 & 549.0 & 18.15 & & -1.34 & -5.91 \\
\hline 11RATJP85A26 & 11JPS4 & 553.0 & 17.93 & & & \\
\hline 11RATJP85A27 & 11JPS4 & 554.9 & 18.18 & & -1.58 & -7.19 \\
\hline 11RATJP86A01 & 11JPS5 & 297.5 & & & 0.66 & -10.79 \\
\hline 11RATJP86A02 & 11JPS5 & 336.2 & & -0.98 & -1.25 & -11.82 \\
\hline 11RATJP86A02 duplicate & 11JPS5 & 336.2 & & -2.48 & & \\
\hline 11RATJP86A03 & 11JPS5 & 346.1 & & 19.96 & -1.54 & -10.26 \\
\hline
\end{tabular}


Table 4 (continued)

\begin{tabular}{|c|c|c|c|c|c|c|}
\hline Sample number & section & Stratigraphic Height $(\mathrm{m})$ & $\delta^{34} S_{\text {evap }}(\%$ CDT) & $\delta^{34} S_{\text {CAS }}(\% \circ C D T)$ & $\delta^{13} C_{\text {carb }}$ (\%o VPDB) & $\delta^{18} \mathrm{O}_{\text {carb }}(\% \circ \mathrm{VPDB})$ \\
\hline 11RATJP90A01 & 11JPS6 & 460.4 & & 20.87 & -2.79 & -8.08 \\
\hline 11RATJP90A01 duplicate & 11JPS6 & 460.4 & & & -2.79 & -8.09 \\
\hline 11RATJP90A02 & 11JPS6 & 462.6 & & 20.68 & -2.68 & -7.37 \\
\hline 11RATJP90A03 & 11JPS6 & 467.4 & & 19.64 & -2.10 & -6.31 \\
\hline 11RATJP90A04 & 11JPS6 & 468.8 & & & -2.26 & -6.44 \\
\hline 11RATJP90A05 & 11JPS6 & 471.2 & & 20.65 & -2.19 & -6.25 \\
\hline
\end{tabular}

Table 5: Kilian Formation CAS concentration and multiple sulphur isotopic composition

\begin{tabular}{|c|c|c|c|c|c|c|}
\hline Sample number & CAS concentration (ppm) & $\delta^{34} S_{\text {CAS }}(\% \circ C D T)$ & $\Delta^{33} \mathrm{~S}_{\text {CAS }}(\% \circ)$ & $\Delta^{36} \mathrm{~S}_{\text {CAS }}(\% \circ)$ & $\Delta^{33} S_{\text {CAS }}^{\prime}(\% o)$ & $\Delta^{36} S_{C A S}^{\prime}(\%)$ \\
\hline 11RATJP43A09 & 16.25 & 26.74 & -0.011 & -1.479 & -0.099 & -0.601 \\
\hline 11RATJP43A10 & 20.04 & 33.29 & -0.135 & -1.546 & -0.271 & -0.266 \\
\hline 11RATJP43A16 & 14.78 & 27.28 & -0.004 & -0.937 & -0.095 & -0.028 \\
\hline 11RATJP43A18 & 10.73 & 29.09 & -0.047 & -1.624 & -0.151 & -0.610 \\
\hline 11RATJP75A21 & 16.43 & 36.25 & -0.012 & -0.894 & -0.173 & 0.591 \\
\hline 11RATJP75A22 & 23.87 & 38.99 & -0.011 & -0.779 & -0.197 & 0.908 \\
\hline 11RATJP75A23 & 40.45 & 42.61 & -0.011 & -1.170 & -0.233 & 0.806 \\
\hline 11RATJP75A24 & 13.68 & 34.03 & -0.007 & -0.841 & -0.149 & 0.488 \\
\hline 11RATJP75A26 & 7.17 & 36.36 & -0.061 & -1.073 & -0.223 & 0.419 \\
\hline 11RATJP75A28 & 5.40 & 28.45 & -0.060 & -1.243 & -0.159 & -0.267 \\
\hline 11RATJP75A29 & 7.36 & 34.03 & -0.042 & -1.348 & -0.184 & -0.019 \\
\hline 11RATJP84A01 & 26.32 & 34.45 & -0.027 & -0.583 & -0.173 & 0.775 \\
\hline 11RATJP84A02 & 24.60 & 29.40 & -0.052 & -0.607 & -0.158 & 0.426 \\
\hline
\end{tabular}


Table 5 (continued)

\begin{tabular}{|c|c|c|c|c|c|c|}
\hline Sample number & CAS concentration (ppm) & $\delta^{34} S_{\text {CAS }}(\% \circ C D T)$ & $\Delta^{33} S_{\text {CAS }}(\%)$ & $\Delta^{36} \mathrm{~S}_{\text {CAS }}(\%)$ & $\Delta^{33} S^{\prime}{ }_{C A S}(\%)$ & $\Delta^{36} S^{\prime}{ }_{\text {CAS }}(\% \circ)$ \\
\hline 11RATJP84A02 & 42.97 & 31.46 & -0.038 & -0.838 & -0.160 & 0.322 \\
\hline 11RATJP84A04 & 11.06 & 36.83 & -0.064 & -0.662 & -0.230 & 0.864 \\
\hline 11RATJP84A05 & 12.24 & 35.44 & -0.065 & -0.663 & -0.117 & -0.098 \\
\hline 11RATJP84A07 & 24.44 & 38.80 & -0.023 & -0.669 & -0.177 & 0.758 \\
\hline 11RATJP84A08 & 90.01 & 32.40 & -0.021 & -0.677 & -0.205 & 0.996 \\
\hline 11RATJP84A10 & 52.46 & 36.34 & -0.168 & -2.358 & -0.297 & -1.138 \\
\hline 11RATJP84A11 & 21.43 & 34.25 & -0.141 & -2.063 & -0.303 & -0.572 \\
\hline 11RATJP84A12 & 10.98 & 24.98 & -0.033 & -0.463 & -0.177 & 0.881 \\
\hline 11RATJP84A13 & 33.63 & 31.37 & -0.176 & -1.950 & -0.253 & -1.167 \\
\hline 11RATJP84A15 & 3.13 & 20.51 & -0.031 & -0.674 & -0.152 & 0.480 \\
\hline 11RATJP84A16 & 55.29 & 29.82 & -0.149 & -2.041 & -0.259 & -0.984 \\
\hline 11RATJP85A02 & 24.34 & 21.67 & -0.062 & -0.524 & -0.120 & 0.094 \\
\hline 11RATJP85A04 & 10.90 & 18.85 & 0.005 & -1.491 & -0.039 & -0.998 \\
\hline 11RATJP85A06 & 18.87 & 20.85 & -0.026 & -0.740 & -0.080 & -0.160 \\
\hline 11RATJP85A08 & 12.60 & 17.34 & -0.012 & -1.553 & -0.049 & -1.123 \\
\hline 11RATJP85A09 & 12.91 & 21.16 & -0.006 & -1.431 & -0.061 & -0.836 \\
\hline 11RATJP85A11 & 66.99 & 36.64 & -0.039 & -0.826 & -0.203 & 0.687 \\
\hline 11RATJP86A02 & 68.04 & -0.98 & -0.021 & -0.336 & -0.022 & -0.345 \\
\hline 11RATJP86A02 & 64.72 & -2.48 & -0.069 & -1.443 & -0.070 & -1.463 \\
\hline 11RATJP86A03 & 42.57 & 19.96 & -0.175 & -1.939 & -0.224 & -1.400 \\
\hline 11RATJP90A01 & 58.72 & 20.87 & -0.109 & -2.071 & -0.162 & -1.490 \\
\hline 11RATJP90A02 & 81.77 & 20.68 & -0.090 & -1.270 & -0.143 & -0.698 \\
\hline 11RATJP90A03 & 109.39 & 19.64 & 0.006 & -0.790 & -0.042 & -0.264 \\
\hline 11RATJP90A05 & 144.52 & 20.65 & -0.114 & -2.043 & -0.166 & -1.472 \\
\hline
\end{tabular}




\subsection{Reliability of isotope data}

Precision of CAS isotope data

To test the precision of the isotope data from the Kilian Formation, repeat analyses were conducted on select samples. The precision, or repeatability, is lowest in CAS isotope data (Table 5). This is a reflection of all possible isotope effects associated with the sample extraction and preparation procedure (Appendix 2). In general, the precision of the measurement decreases with the minor isotopes (e.g. $\mathrm{S}^{33} \mathrm{~S}^{36}$ ) and is lowest in $\Delta^{36} \mathrm{~S}_{\text {CAS }}$ measurements, from which no conclusions are drawn. To test the signal to noise ratio of $\delta^{34} \mathrm{~S}_{\mathrm{CAS}}$ and $\Delta^{33} \mathrm{~S}_{\mathrm{CAS}}$ data, the $2 \sigma$ uncertainty for each parameter was calculated. Large overlap in the uncertainty of individual $\Delta^{33} \mathrm{~S}_{\text {CAS }}$ measurements precludes detection of secular trends. However inter-comparison between Kilian Formation and Minto Inlet Formation results is still possible as they are easily differentiated, even with the uncertainty in CAS results (Figure 22). 


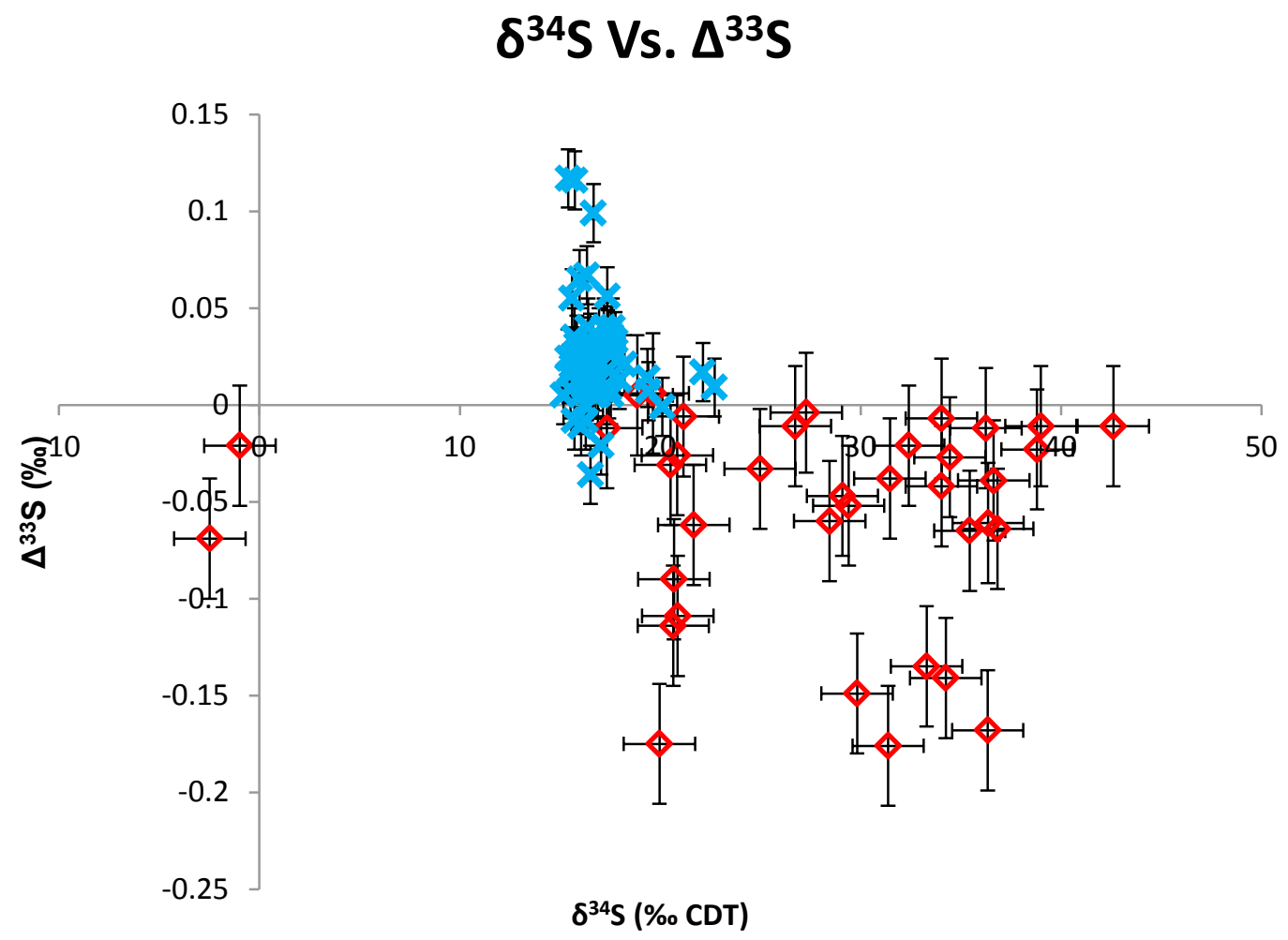

Figure 22: Sulphur isotope data from the Minto Inlet (blue crosses) and Kilian formations (red diamonds). Error bars on data represent $2 \sigma$ uncertainty.

\section{CAS concentrations}

The measurement of CAS in some cases relies on the extraction of sulphate at very low concentrations (sometimes only 10 s of $\mathrm{ppm}$ ). $\delta^{34} \mathrm{~S}_{\mathrm{CAS}}$ values will be shifted, generally toward lower isotopic values, if sulphide minerals in the sample are oxidized to sulphate during diagenesis or during sample preparation (Marenco et al., 2008). The CAS concentrations of the Kilian Formation dataset range from a few ppm to 100 s of ppm. In order to test for potential contamination of samples by oxidation of pyrite, the concentration of CAS (in ppm) was calculated for each of the samples, the results are presented in Table 3 and Figure 23. If samples were contaminated by the oxidation of 
pyrite, one would expect a negative correlation between their CAS concentration and $\delta^{34} S_{\text {CAS }}$ (Marenco et al., 2008). This is because pyrite is typically depleted in $\delta^{34} \mathrm{~S}$, so samples that have been contaminated by the oxidation of pyrite should have both elevated CAS concentrations and depleted $\delta^{34} S$ values. Since there is no significant correlation between CAS concentrations and $\delta^{34} S_{C A S}\left(R^{2}=.095\right)$ in the Kilian Formation dataset, significant contamination by pyrite sulphur can be ruled out.

\section{CAS concentration Vs. $\delta^{34} \mathrm{~S}_{\mathrm{CAS}}$}

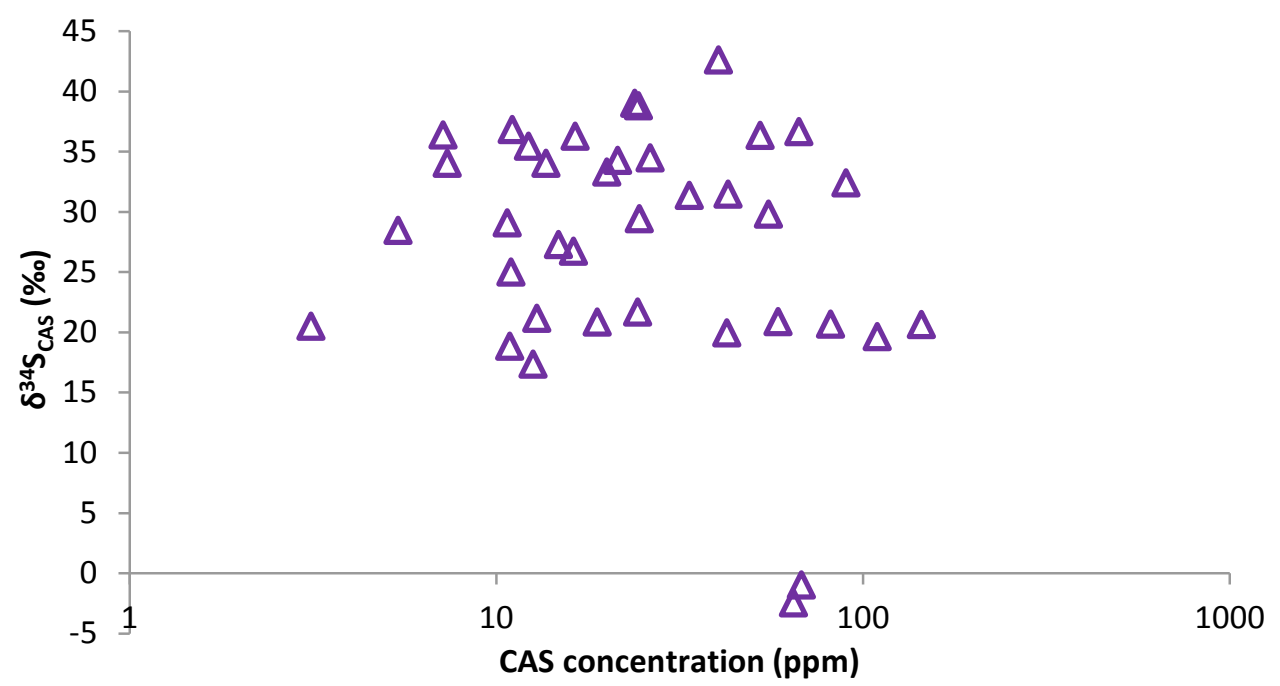

Figure 23: CAS concentration vs CAS sulphur isotope composition of Kilian Formation samples. The poor correlation $\left(R^{2}=0.095\right)$ helps to support the hypothesis that pyrite oxidation did not significantly alter $\delta^{34} S_{\text {CAS. }}$.

\section{C-O covariance}

Correlation of $\delta^{18} \mathrm{O}$ and $\delta^{13} \mathrm{C}_{\text {carb }}$ in carbonate samples, especially in depleted values, is often regarded as an indicator of the diagenetic resetting of those values (Bathurst, 1972; Derry, 2010), although covariance between $\delta^{18} O$ and $\delta^{13} C_{\text {carb }}$ can be produced by other mechanisms (Veizer et al., 1999). Cross plots of all $\delta^{18} \mathrm{O}$ and $\delta^{13} \mathrm{C}_{\text {carb }}$ 

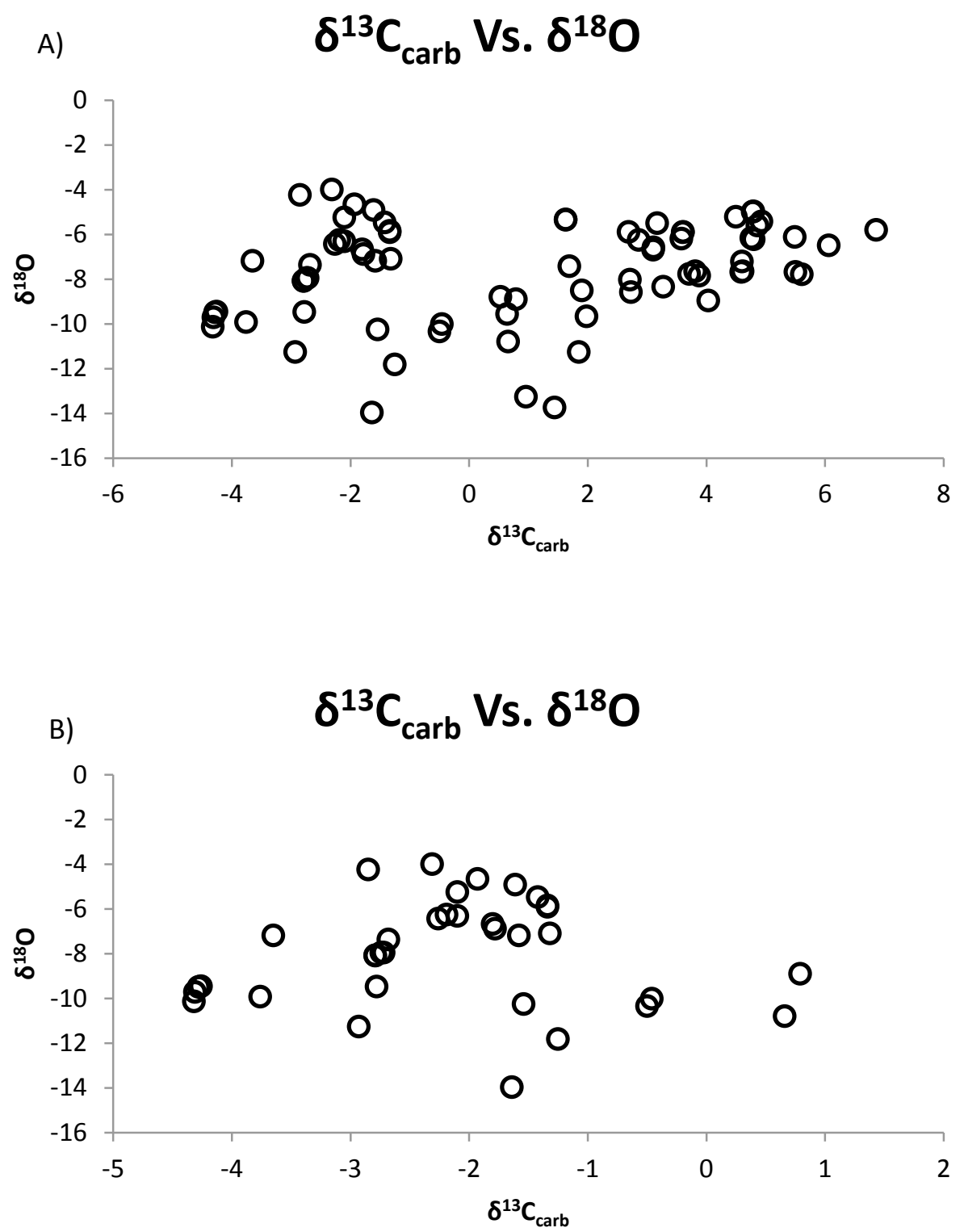

Figure 24: Cross plots of $\delta^{13} \mathrm{C}_{\text {carb }}$ and $\delta^{18} \mathrm{O}$ data from the Kilian Formation. A) All data from the Kilian Formation are plotted $R^{2}=0.065$. B) Only the most depleted values from the Kilian Formation are plotted $R^{2}=3 \times 10^{-5}$. The poor correlation in both plots is consistent with a primary rather than diagenetic origin for the $\delta^{13} C_{\text {carb }}$ values. 
data and of the most depleted $\delta^{13} \mathrm{C}_{\text {carb }}$ values from the Kilian Formation (Figure 24) show little correlation, $\mathrm{R}^{2}=0.065$, and $3 \times 10^{-5}$, respectively, thereby supporting a primary origin for $\delta^{13} \mathrm{C}_{\text {carb }}$ values.

\subsection{Secular isotope trends in the Minto Inlet Formation:}

The sulphur isotope composition of the sulphate evaporites through the Minto Inlet Formation is very consistent; the $\delta^{34} \mathrm{~S}_{\mathrm{ev}}$ fluctuates $<8 \%$ o over $\sim 270 \mathrm{~m}$ of stratigraphic section (Figure 25, Table 1). The $\delta^{34} \mathrm{~S}_{\mathrm{ev}}$ values range from $15 \%$ o to $22 \%$ ond average $\sim 17 \%$ o with a standard deviation of $1.4 \%$. Even across important lithostratigraphic boundaries the $\delta^{34} \mathrm{~S}_{\mathrm{ev}}$ seems to be buffered against isotopic fluctuations. $\Delta^{33} \mathrm{~S}_{\mathrm{ev}}$ values are generally low (0-0.12) and positive, while showing a general increase in their dispersion up-section, $\Delta^{33} \mathrm{~S}_{\mathrm{ev}}$ data show little secular variability (standard deviation $=0.026 \%$ ). Carbon isotope data (Figure 25; Thomson et al., 2011) show a general $\sim 3-4 \%$ o enrichment in $\delta^{13} \mathrm{C}_{\text {carb }}$, slightly less than the $5 \%$ mean value typical of the early Neoproterozoic carbon isotope record (Halverson et al., 2009). There is an offset in $\delta^{13} \mathrm{C}_{\text {carb }}$ at $\sim 150 \mathrm{~m}$, characterized by an initial drop of $\sim 2 \%$ which is followed an abrupt increase of $\sim 4 \%$. This interval coincides with the lithostratigraphic contact between the lower evaporite member and the carbonate member and is interpreted as an important flooding surface (see section 2.4). The offset may reflect the isotopic re-equilibration of DIC in the previously restricted basin with that of the open ocean. 


\section{Minto Inlet Formation}

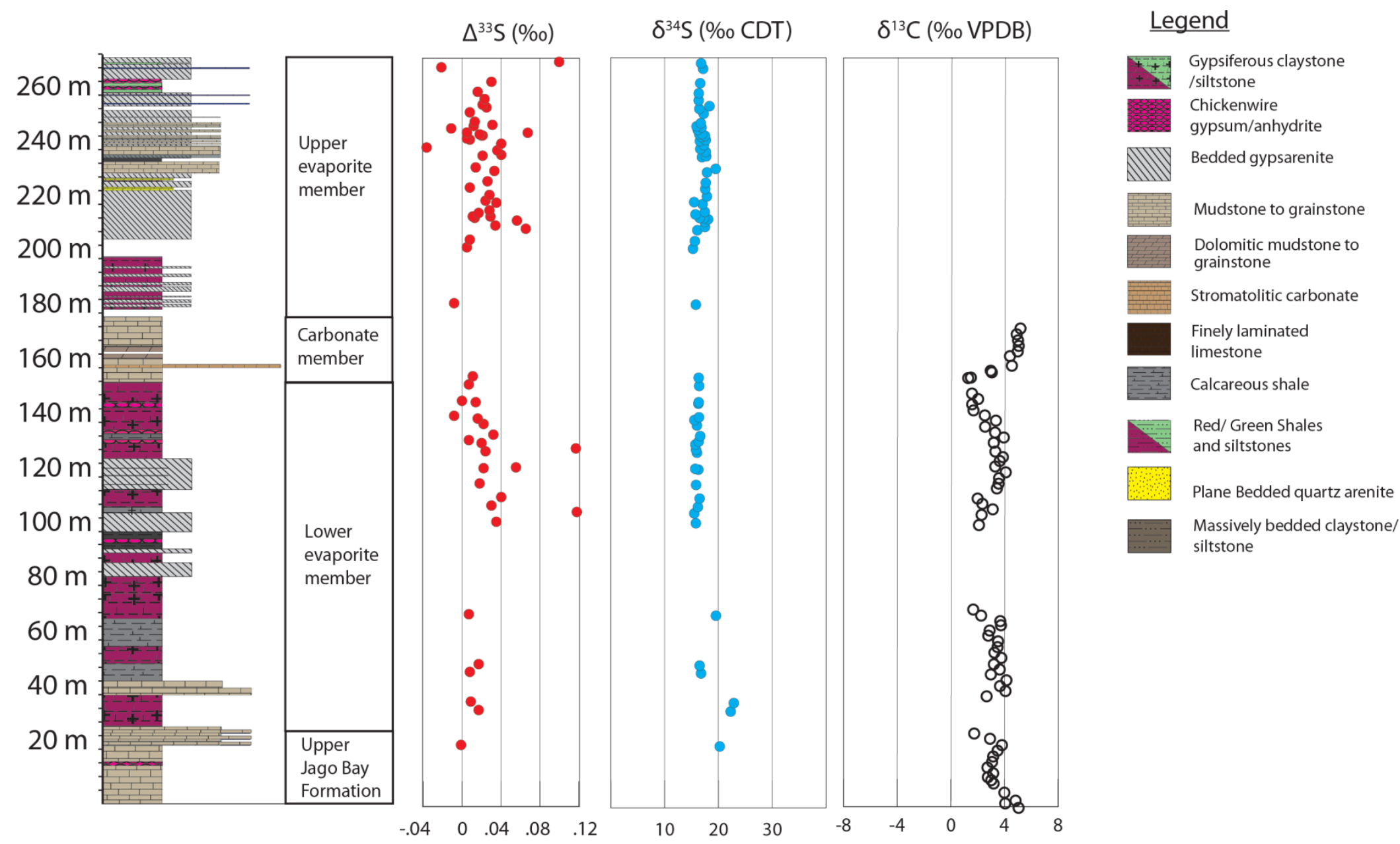

Figure 25: Isotope stratigraphy of the Minto Inlet Formation. $\delta^{13} \mathrm{C}$ data from Thomson et al.(2011). 


\subsection{Secular isotope trends in the Kilian Formation}

The $\delta^{13} C_{\text {carb }}$ values of the Kilian Formation show large (>10\%) variability (Figure 26), which is extremely rare in Earth history but is more common in the Neoproterozoic (Halverson et al., 2010). Values at the base of the Kilian Formation increase from 2\%o to $\sim 6 \%$ o through $\sim 60 \mathrm{~m}$ of section before slowly decreasing again. There is a clear $\sim 3 \%$ o offset in $\delta^{13} \mathrm{C}_{\text {carb }}$ at $\sim 100 \mathrm{~m}$, coinciding with the boundary between sequences $\mathrm{B} 5$-I and B5-II. Above the sequence boundary there is an abrupt and rapid increase from $2 \%$ o to $\sim 7 \%$ over $\sim 5 \mathrm{~m}$ of stratigraphic section. Limited exposure precludes analysis of secular isotope trends between $140 \mathrm{~m}$ and $200 \mathrm{~m}$. At $200 \mathrm{~m}$, the $\delta^{13} \mathrm{C}_{\text {carb }}$ values are relatively enriched (>5\%o) but decline consistently to 0\%o through the upper cyclic carbonate member. The sampling record is sparse through the clastic-carbonate member, a few data points indicate that the negative trend through the upper cyclic carbonate member persists, reaching values as low as $-1.54 \%$ at $\sim 345 \mathrm{~m}$. A slight increase in $\delta^{13} \mathrm{C}_{\text {carb }}$ through the lower tan carbonate member gives way to steeply plunging values through the upper tan carbonate member (Figure 26). The lowest $\delta^{13} \mathrm{C}_{\text {carb }}$ values recorded in the Kilian Formation ( $-4.5 \%$ ) come from the interval containing the lithostratigraphic contact between the tan carbonate member and the upper evaporite member. The $\delta^{13} \mathrm{C}_{\text {carb }}$ values increase upward through the upper evaporite member to a plateau of $1.4 \%$ at $\sim 530 \mathrm{~m}$. The steady decline in $\delta^{13} \mathrm{C}_{\text {carb }}$ values through the upper Kilian Formation has been correlated with the globally recognized Islay carbon isotope stage (Jones et al., 2010) based on appropriate timing and magnitude of the excursion. 
Sulphate minerals are only abundant in the lower and middle evaporite members and near the top of the section in the upper evaporite member. There are significant fluctuations (>6\%o) in the $\delta^{34} \mathrm{~S}_{\mathrm{ev}}$ signature over relatively short stratigraphic intervals $(<25 \mathrm{~m})$ particularly in the lower evaporite member (Figure 26$)$. The sulphur isotope composition of the lower and middle evaporite members is also significantly enriched (average $32.4 \%$ ) relative to both average modern marine seawater $(20.8 \%$; Kampschulte et al., 2001) and average values from the Minto Inlet Formation (average = $16.8 \%$ ). The $\delta^{34} \mathrm{~S}_{\mathrm{ev}}$ signature from the upper evaporite member is much closer to modern marine and Minto Inlet Formation values. These values are much more consistent, only varying between 18 and $21 \%$ over $65 \mathrm{~m}$ of stratigraphic section.

There is a general agreement between $\delta^{34} S_{e v}$ and $\delta^{34} S_{\text {CAS }}$ where the two overlap in the upper evaporite member (Figure 26). There is high $\delta^{34} S_{\text {CAS }}$ variability $(10-20 \%$ ) in both of the cyclic carbonate members and each carbonate unit appears to record an initial increase in $\delta^{34} S_{\text {CAS }}$ which is followed by an even larger decline. Anomalously low $\delta^{34} \mathrm{~S}_{\text {CAS }}$ values ( -2\%o) in the clastic-carbonate member are difficult to explain as there is sparse sampling through it. A gradual but continuous decrease in $\delta^{34} S_{\text {CAS }}$ occurs through the tan carbonate member ultimately reaching a steady value of $\sim 20 \%$ o. This value persists in $\delta^{34} S_{e v}$ for the remainder of the Kilian section (Figure 26). 


\section{Kilian Formation}

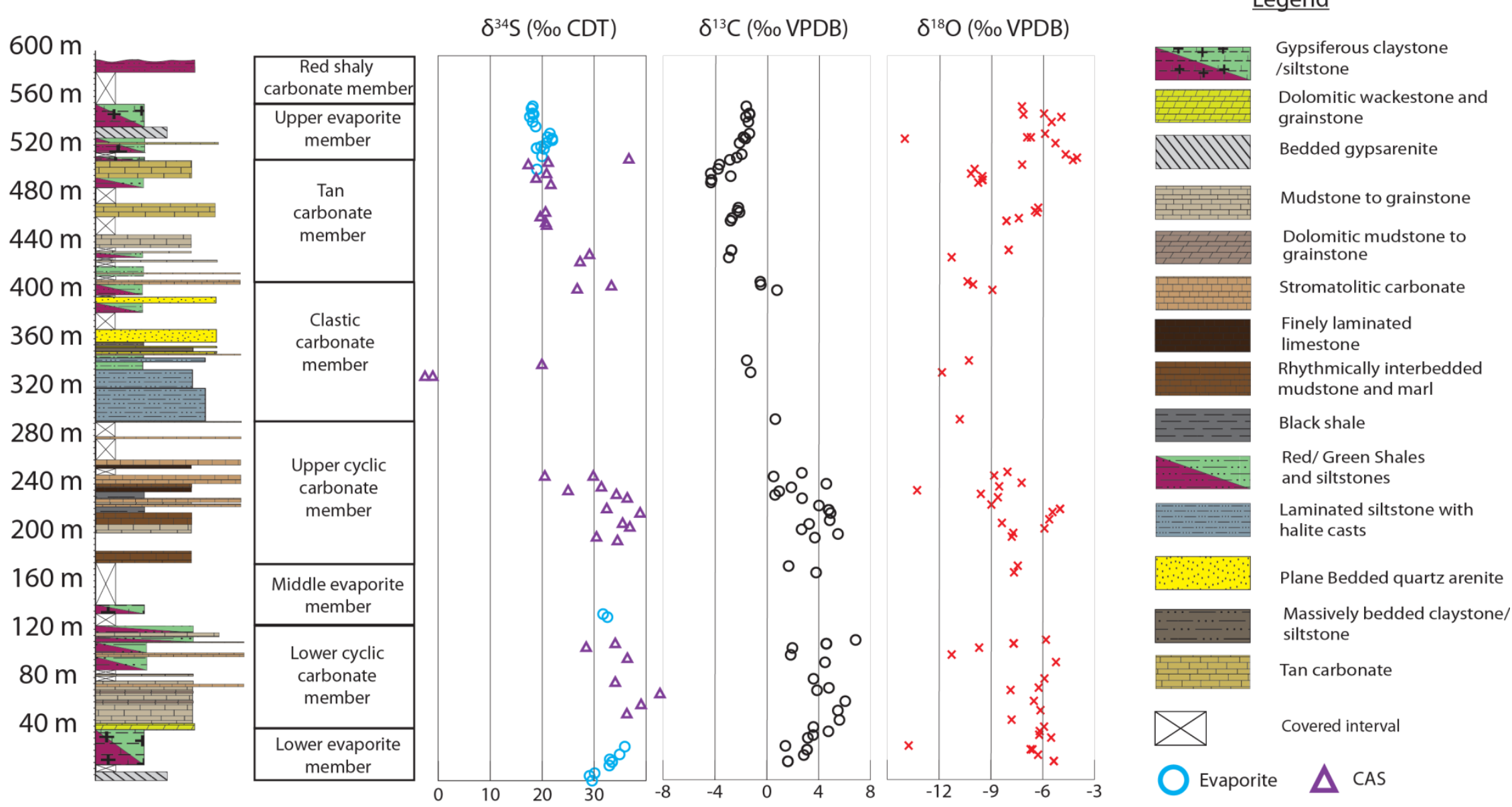

Figure 26: Isotope stratigraphy of the Kilian Formation 


\subsection{Models of the biogeochemical cycles of sulphur and carbon}

The carbon and sulphur isotope patterns observed in the rocks of the Minto Inlet and Kilian formations are interpreted to reflect the global biogeochemical conditions at the time of their respective deposition. This requires that the local/basinal isotope reservoirs were buffered by the global ocean reservoirs via seaways connecting the two during sea level highs. This interpretation is supported by the recognition of at least two globally correlated carbon isotope excursions in carbonate samples from the Wynniatt and Kilian formations (Jones et al., 2010). Steady state and non-steady state modelling techniques based on the current understanding of the cycling of carbon and sulphur isotopes through the oceans and lithosphere (e.g. Berner, 1987; Bartley and Kah, 2004; Canfield, 2004; Kah et al., 2004; Berner, 2005) make it possible to constrain important parameters, which characterize these biogeochemical conditions (e.g. the mass of the seawater sulphate and DIC reservoirs, $f_{p}$ and $\left.f_{\text {Corg }}\right)$. The $C$ and $S$ isotope data from the Minto Inlet and Kilian formations provide insight into these changing parameters and, more generally, into the evolution of the cycling of sulphur and carbon through the middle Neoproterozoic.

Non-steady state model

Non-steady state models of the marine sulphur and carbon cycles allow for increases or decreases in the flux of those elements either entering or leaving the oceans. In a non-steady state system, variability in $\delta^{34} S$ and $\delta^{13} \mathrm{C}$ of sea water reflects the sensitivity of the seawater sulphate and DIC reservoirs, respectively, to natural 
perturbations (Bartley and Kah, 2004; Kah et al., 2004). Thus the buffering of the reservoir against isotopic variation is a function of the mass of the reservoir. By using $\delta^{34} \mathrm{~S}_{\text {evap, }} \delta^{34} \mathrm{~S}_{\text {CAS }}$ and $\delta^{13} \mathrm{C}_{\text {carb }}$ as approximations for the isotopic composition of the seawater sulphate reservoir and DIC respectively, it is possible to use stratigraphic variability to constrain the relative size of each of those reservoirs (Figure 26; Bartley and Kah, 2004; Kah et al., 2004).
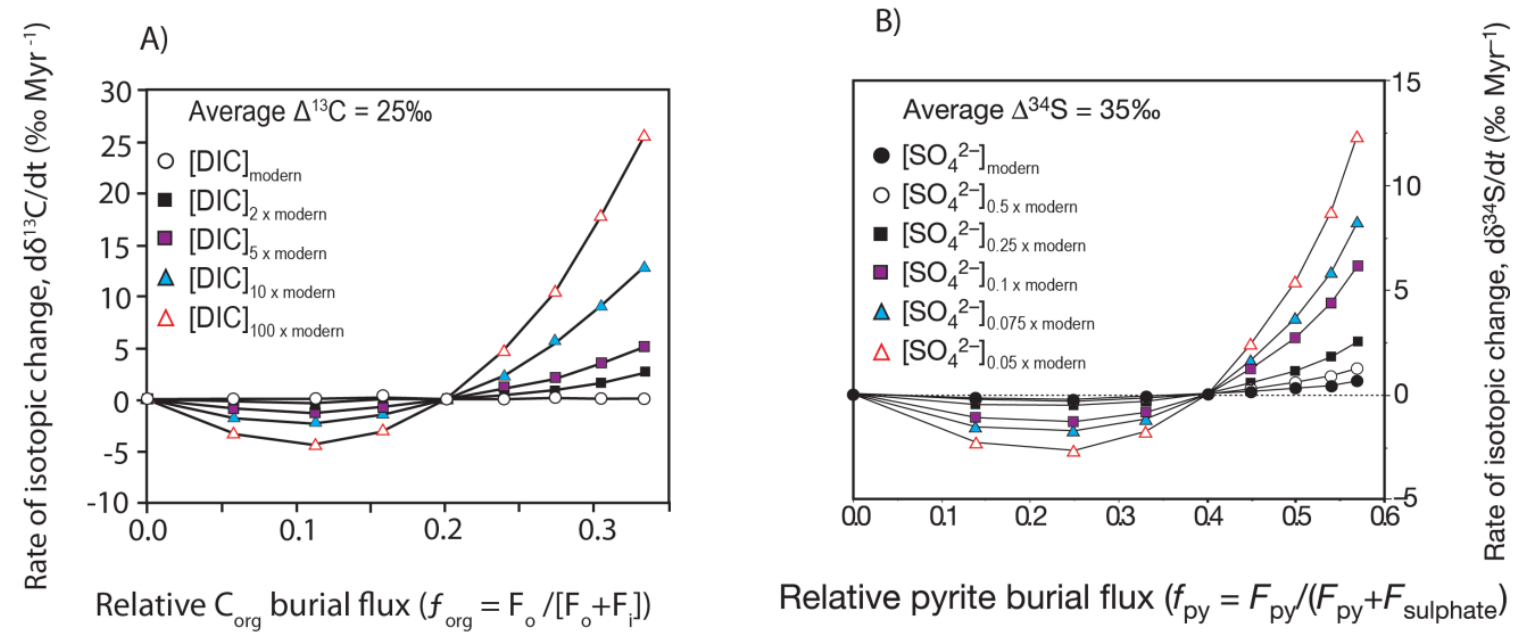

Relative pyrite burial flux $\left(f_{\mathrm{py}}=F_{\mathrm{py}} /\left(F_{\mathrm{py}}+F_{\text {sulphate }}\right)\right.$

Figure 27: A) Isotopic sensitivity of the of inorganic carbon reservoir with respect to reservoir size and burial fraction of organic carbon, after Bartley and Kah (2004). B) Isotopic sensitivity of the of seawater sulphate reservoir with respect to reservoir size and pyrite burial fraction (Kah et al., 2004).

The $\delta^{34} \mathrm{~S}_{\mathrm{ev}}$ of the Minto Inlet Formation is relatively invariant with a standard deviation of $1.36 \%$. According to the model of Kah et al. (2004; Figure 26b) this suggests that the seawater sulphate reservoir was large and therefore buffered against isotopic change or that pyrite burial was insignificant, or a combination of both. 
In contrast, the Kilian Formation displays up to $20 \%$ o systematic shifts in $\delta^{34} \mathrm{~S}$ over stratigraphic intervals of $<100 \mathrm{~m}$ (Figure 26). Variability of this magnitude reflects a small seawater sulphate reservoir and/or significant pyrite burial during deposition. Similarly, large variability in $\delta^{13} \mathrm{C}_{\text {carb }}$ through the Kilian Formation is indicative of a small DIC reservoir, a high fraction of $\mathrm{C}_{\text {org }}$ burial or a combination of both, according to the non-steady state model of Bartley and Kah (2004).

This means that there was a significant change in the cycling of sulphur that must have occurred between the deposition of the Minto Inlet and Kilian formations, which can be explained by either an increase in the pyrite burial fraction or a decrease in the size of the marine sulphate reservoir or a combination of the two.

\section{Steady state model}

Whereas the non-steady state model assumes that the volume of individual geochemical reservoirs varies through time, the steady state models, which are valid over shorter time intervals, operate by assuming that the volume of those reservoirs remains constant. In steady state models it is only the proportional burial of either the oxidized or reduced species of sulphur and carbon that control the isotopic signature of their respective seawater reservoir. For example, in a steady state model an increase in the fractional burial of pyrite relative to sulphate would drive the seawater sulphate reservoir to higher isotopic values because of the removal of isotopically light sulphur, buried in sedimentary sulphide. 
Typically, steady state models require the independent measurement of both $\delta^{34} S_{p y}$ and $\delta^{34} S_{e v}$. However since the data from this study do not include $\delta^{34} S_{p y}$, the multiple sulphur isotopes from sulphate will be used as a proxy to estimate $\delta^{34} S_{p y}$.

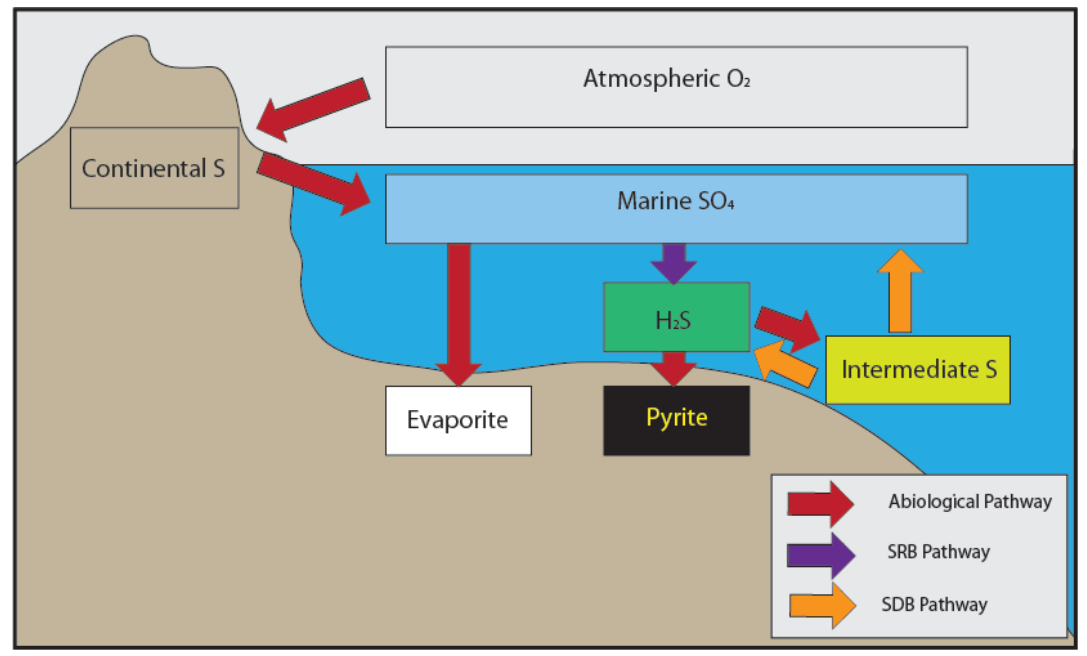

Figure 28: The sulphur cycle, depicting important sulphur fluxes into and out of the ocean

The model presented below is based on the marine sulphur cycle depicted in Figure 28 and the following two equations.

$$
\begin{aligned}
& f_{p}=\frac{\left(\delta^{34} S_{\text {sulphate }}-\delta^{34} S_{\text {weathering }}\right)}{\Delta^{34} S_{\text {ev }-p}} \\
& f_{p}=\frac{\Delta^{33} S_{\text {ev }}}{\Delta^{34} S_{\text {ev }-p}\left(\lambda^{33} \text { bio }-\lambda^{33} T F L\right)}
\end{aligned}
$$

The first expression is derived from mass balance equations and defines an inverse relationship between $f_{p}$ and $\Delta^{34} S_{\text {ev-p. }}$. The second is derived from ${ }^{33} S$ systematics, where $\lambda^{33}{ }_{\text {bio }}$ represents of the efficiency of $\delta^{33} S$ fractionation relative to $\delta^{34} S$ 
fractionation due to the combined effects of sulphur-reducing bacteria (SRB) and sulphur disproportionating bacteria (SDB) (e.g. Johnston, 2011). Combining equations 7 and 8 results in a third expression to solve for $\lambda^{33}$ bio

$$
\lambda_{\text {bio }}^{33}=\frac{\Delta^{33} S_{\text {ev }}}{\left(\delta^{34} S_{\text {sulphate }}-\delta^{34} S_{\text {weathering }}\right)}+\lambda^{33} \text { TFL }
$$

The $\lambda^{33}$ bio representative of each sample is calculated using a measured value for both $\delta^{34} S_{\text {ev }}$ and $\Delta^{33^{\prime}} S_{\text {ev }}$ and an assumed value for $\delta^{34} S_{\text {weathering. Values for }} \delta^{34} S_{\text {weathering }}$ in the literature typically range from 0-8\%o, (e.g. 3\%; Holser, 1988; Canfield, 2004, $6 \%$; Hurtgen et al., 2002, 8\%; Garrels and Lerman, 1981). However, since $\delta^{34} S_{\text {weathering values }}$ should vary over time it is impossible to predict its exact value. A $\delta^{34} S_{\text {weathering }}$ value of $3 \%$ was used and the effects of varying this parameter from $0-8 \%$ were tested.

The $\lambda^{33}$ bio of each sample was then used to constrain $\Delta^{34} S_{\text {ev-py }}$ using relationships between these two variables derived from experimental correlation in both sulphate reducing bacteria and sulphur disproportionating bacteria systems (Johnston et al., 2005a; Johnston et al., 2007; Sim et al., 2011a; Sim et al., 2011b; Leavitt et al., 2013; see Figure 28). The $\lambda^{33}$ bio data from the Minto Inlet and Kilian formations were fitted according to the following equations, which represent best fit lines for the experimental data mentioned above and presented graphically in Figure 29.

$$
\begin{aligned}
& \text { When } 0.5162<\lambda_{\text {bio }}^{33} \geq 0.5230 \Delta^{34} S_{\text {ev-py }}=-3.29 * 10^{-4} \lambda^{33} \text { bio }+0.526547 \\
& \text { When } 0.5150<\lambda^{33}{ }_{\text {bio }} \geq 0.5162 \Delta^{34} S_{\text {ev-py }}=-1.14 * 10^{-4} \lambda^{33} \text { bio }+0.519687 \\
& \text { When } 0.5146<\lambda^{33}{ }_{\text {bio }} \geq 0.5150 \Delta^{34} S_{\text {ev-py }}=-4.00 * 10^{-5} \lambda^{33} \text { bio }+0.516659
\end{aligned}
$$




$$
\begin{aligned}
& \text { When } 0.5144<\lambda^{33}{ }_{\text {bio }} \geq 0.5146 \Delta^{34} S_{\text {ev-py }}=-6.47 * 10^{-6} \lambda^{33}{ }_{\text {bio }}+0.514853 \\
& \text { When } 0.5050<\lambda^{33}{ }_{\text {bio }} \geq 0.5144 \Delta^{34} S_{\text {ev-py }}=8.62 * 10^{-5} \lambda^{33}{ }_{\text {bio }}+0.50845
\end{aligned}
$$

$f_{p}$ was then calculated using either equation 7 or 8 above.

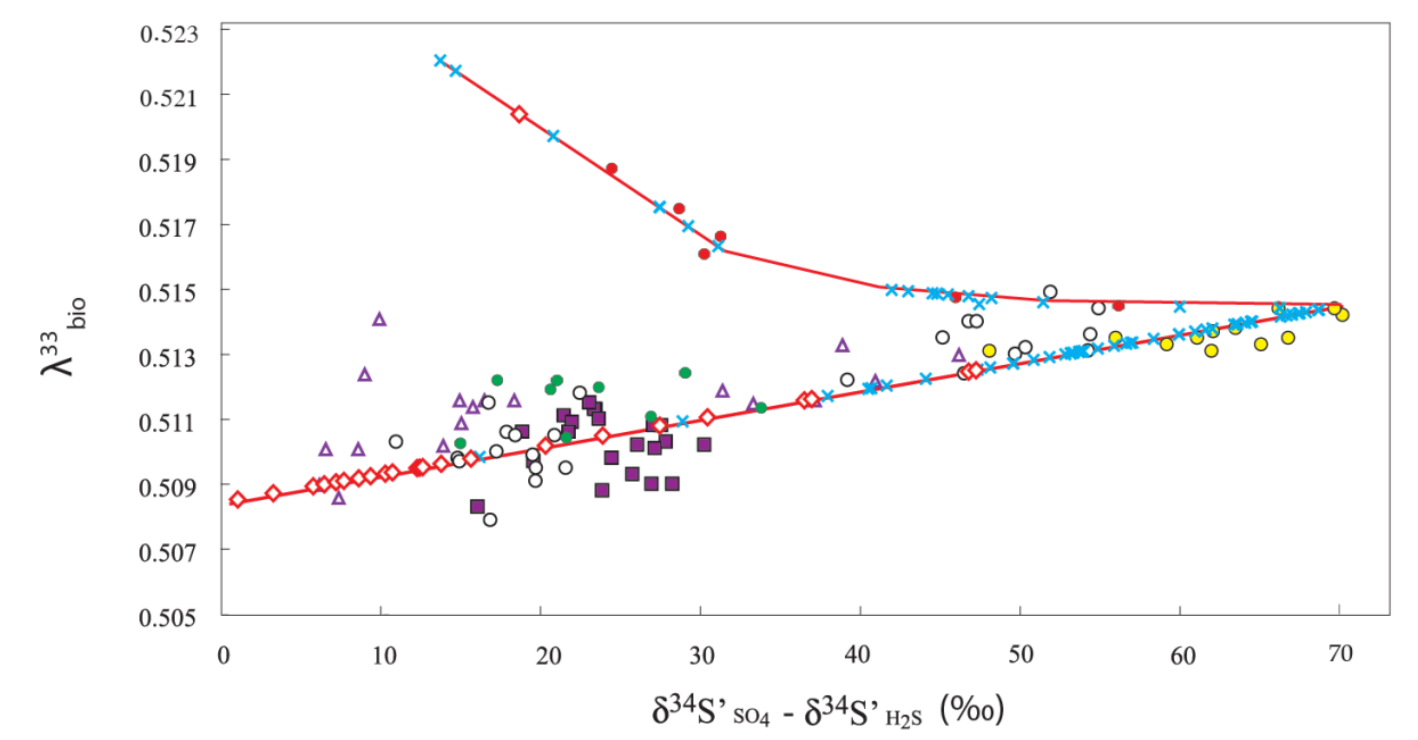

\footnotetext{
○ BSR data from Sim et al., 2011a O BSR data from Leavitt et al., 2013 - BSR data from Johnston et al., 2005a $\diamond$ Kilian Formation

$\Delta$ BSR data from Sim et al., 2011b - BSR data from Johnston et al., 2007 SDB data from Johnston et al., 2005a $\times$ Minto Inlet Formation
}

Figure 29: Experimental relationship between $\lambda^{33}$ bio and $\Delta^{34} \mathrm{~S}_{\mathrm{SO} 4-\mathrm{H} 2 \mathrm{~S}}$ (data from Johnston et al., 2007; Sim et al., 2011a; Sim et al., 2011b; Leavitt et al., 2013). Data from both bacterial sulphate reduction and sulphur disproportionating reactions is included. $A$ linear fitted model (red lines) has been used to plot data from the Minto Inlet and Kilian formations. Relationships between $\lambda^{33}$ bio and $\Delta^{34} S_{\text {ev-py }}$ are vastly oversimplified in the above model; extrapolation beyond the limits of the plot in Figure 29 was avoided. 


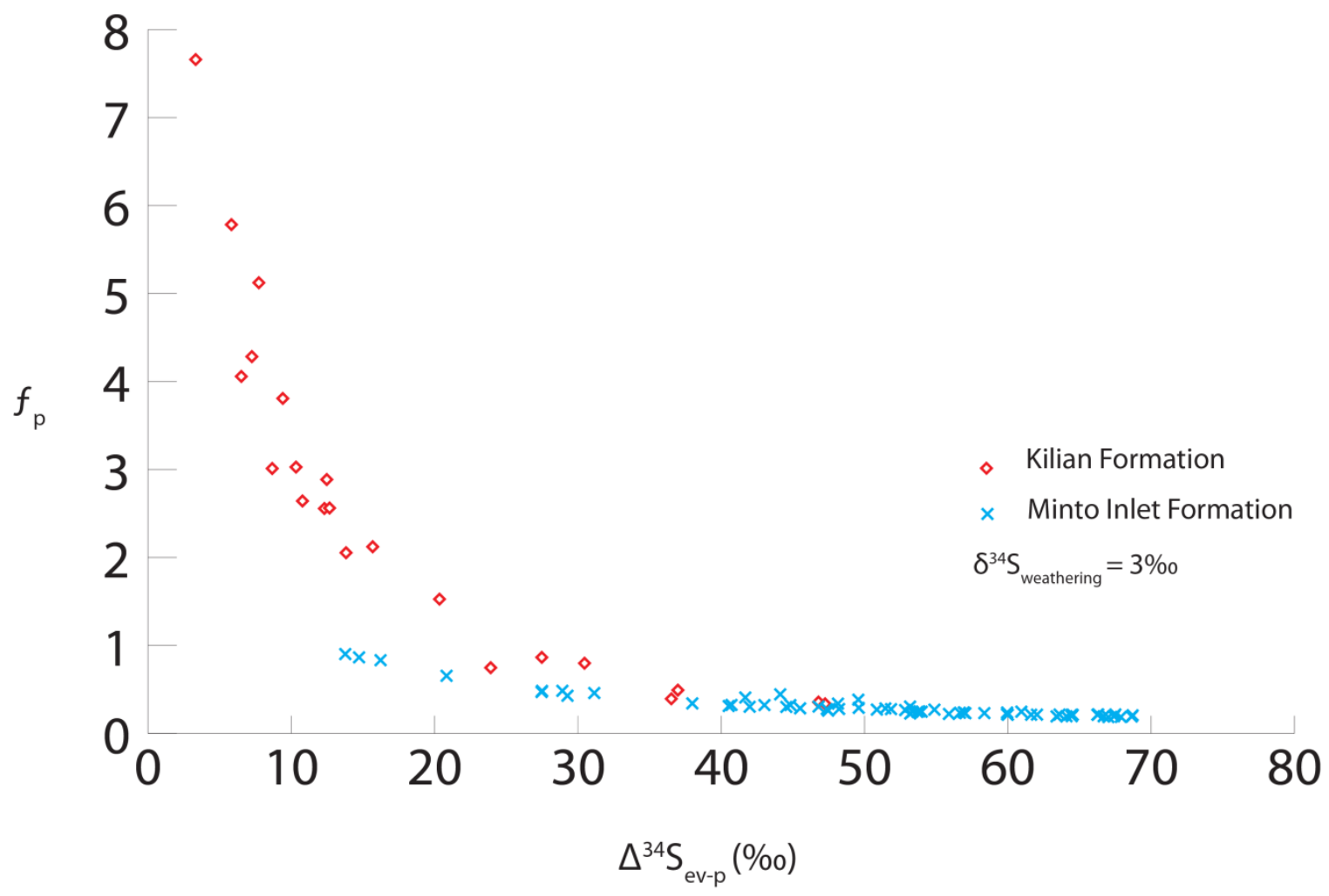

Figure 30: $f_{p}$ vs $\Delta^{34} S_{\text {ev-py }}$ for the Minto Inlet and Kilian formations. Large negative $\Delta^{33^{\prime}} S_{\text {CAS }}$ from the Kilian Formation contributes to the unrealistic (e.g. $>1$ ) values for $f_{p}$.

\section{Results of steady model}

Assuming $\delta^{34} \mathrm{~S}_{\text {weathering }}=3 \%$, the $\Delta^{34} \mathrm{~S}_{\text {ev-py }}$ of the Minto Inlet Formation dataset ranges from $13-68 \%$ with an average of $50 \%$ (Figure 30 ). The average $f_{p}$ of the dataset is 0.3 and ranges from 0.18 to 0.9 . The model presented above was only applied to the CAS data from the Kilian Formation because only these samples were analyzed for multiple sulphur isotopes. Because of strongly negative $\Delta^{33^{\prime}} \mathrm{S}_{\text {CAS }}$ and associated low $\lambda^{33}$ bio, much of the data from the Kilian Formation falls outside of the model parameters 
thereby generating unrealistic values for $f_{p}$ (i.e. $>1$ ). Assuming $\delta^{34} S_{\text {weathering }}=3 \%$, the average $\Delta^{34} S_{\text {ev-py }}$ of the dataset is $17 \%$ and the average $f_{p}$ is above 1.

Varying the assumed $\delta^{34} S_{\text {weathering }}$ between 0 and 8\%o does not significantly alter modeling results (Figure 31); in all cases the average $\Delta^{34} \mathrm{~S}_{\mathrm{ev}-\mathrm{py}}$ remained high for the Minto Inlet Formation, between 42-52\%o, indicating a high degree of fractionation between coeval sulphate and sulphide. The average $f_{p}$ for the Minto Inlet Formation remained low $(0.18-0.36)$, implying that burial of pyrite rather than sulphate was the primary sulphur sink during deposition. Similarly varying the $\delta^{34} S_{\text {weathering }}$ does not significantly alter the results Kilian Formation results; in all cases, low average $\Delta^{34} S_{\text {ev-py }}$ and $f_{p}$ above 1 were generated. Contrary to results from the Minto Inlet Formation, the high $f_{p}$ and low $\Delta^{34} S_{\text {ev-py }}$ of the Kilian Formation samples are similar to previous steady state models for pyrite burial in the Neoproterozoic (e.g. Canfield, 2004). Previous modelling of the evolution of $f_{p}$ through geologic time using $\delta^{34} S_{p y}$ data, binned into time intervals, yielded an average near 1 for published data from the Archean to the late Neoproterozoic (Canfield, 2004). The results of this work suggest that during the midNeoproterozoic, sedimentary pyrite burial went from representing $~ 100 \%$ of the sulphur sink to only $\sim 30 \%$. 


\section{A) Minto Inlet Formation}

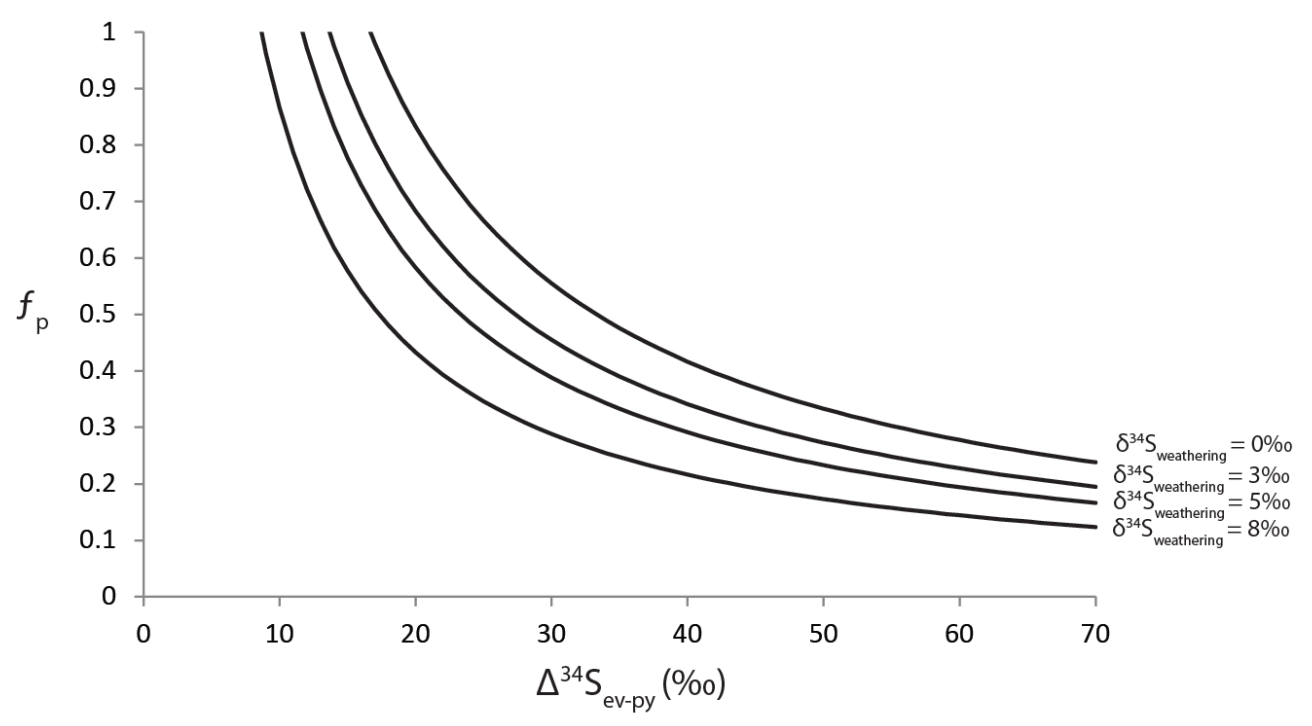

B)

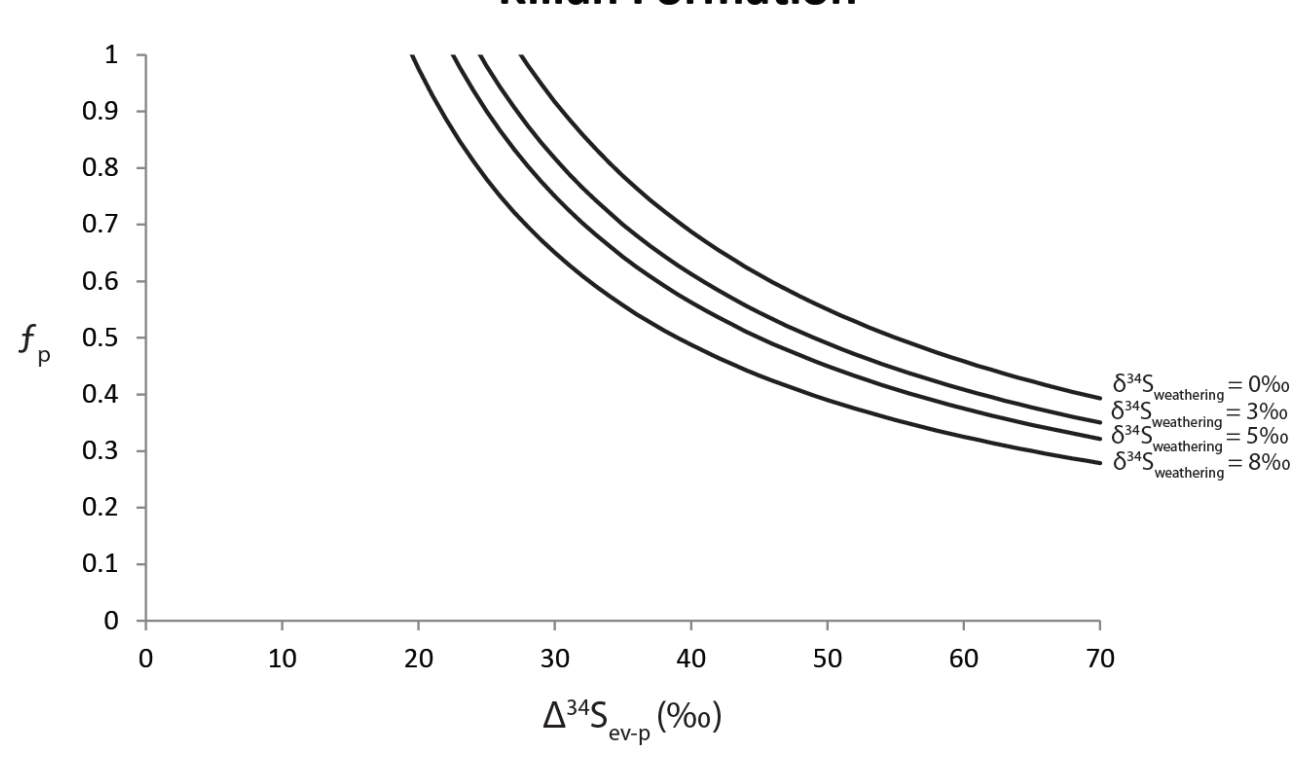

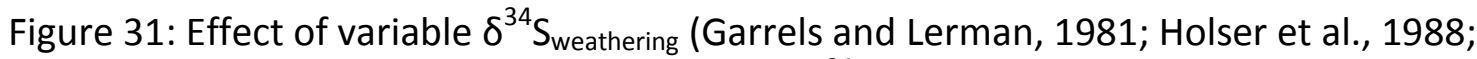
Hurtgen et al., 2002; 0-8\%; Canfield, 2004) on $\Delta^{34} S_{\text {ev-py }}$ and $f_{p}$. A) Plot constructed using the averages of the Minto Inlet Formation dataset. Because the Minto Inlet Formation data plots at generally elevated $\Delta^{34} S_{\text {ev-py }}$ (average $=50 \%$ ), varying the $\delta^{34} S_{\text {weathering }}$ parameter does not greatly alter $f_{p}$. B) Plot constructed using the averages of the Kilian Formation dataset. Data from the Kilian Formation plots at generally low $\Delta^{34} \mathrm{~S}_{\mathrm{ev}-\mathrm{py}}$ (average $=17 \%$ o) 


\subsection{Discussion}

\section{Sulphur isotopes}

Despite having similar evaporite facies preserved, the sulphur isotopes of the Minto Inlet and the Kilian formations have dramatically different $\delta^{34} S$ signatures. The consistency of the $\delta^{34} S_{\text {evap }}$ of the Minto Inlet Formation is interpreted to reflect relatively high concentrations of seawater sulphate, effectively buffered against isotopic change. These results are contrasted with high $\delta^{34} S$ variability in the Kilian Formation, which reflects low marine sulphate concentrations, more susceptible to isotopic variation due to natural perturbations (Kah et al., 2004). This implies that a significant reduction in the sulphate concentration of the oceans occurred at some point during the deposition of the intervening Wynniatt Formation. Steady state modelling of the sulphur cycle, using the multiple sulphur isotopes of evaporites from the Minto Inlet Formation and CAS from carbonate rocks of the Kilian Formation, indicate that while evaporite burial represented the primary global sulphur sink during deposition of the Minto Inlet Formation, pyrite burial was a much more significant sulphur sink during deposition of the Kilian Formation.

Recent work on Phanerozoic evaporites shows that both the deposition and dissolution of basin-scale evaporites has an important effect on the concentration of dissolved seawater sulphate (Halevy et al., 2012; Wortmann and Paytan, 2012; Wortmann and Chernyavsky, 2007). This process is considered to have been less significant during the Precambrian because seawater sulphate concentrations are 
thought to have remained low until the latest Neoproterozoic (e.g. Canfield, 2004; Canfield and Farquhar, 2009) making the formation of basin-scale evaporite deposits highly unlikely. However many thick to mid-Neoproterozoic evaporite deposits are documented (Table 4) including the Ten Stone Formation and The Coates Lake Group in the Mackenzie Mountains (Jefferson, 1983; Turner, 2009; Turner and Long, 2012), which correlate both stratigraphically (Young et al., 1979; Rainbird et al., 1996) and geochemically (Jones et al., 2010; Macdonald et al., 2010) with the Minto Inlet and Kilian formations respectively. This suggests that there was a large seawater sulphate reservoir during the middle Neoproterozoic and that it produced basin-scale sulphate evaporite deposits. While the formation of huge volumes of evaporite minerals was clearly possible, the sulphur isotope modelling suggests that this process dramatically reduced the concentration of seawater sulphate in the global oceans. 
Table 6: Locations of preserved middle Neoproterozoic evaporite deposits with their respective age and volume

\begin{tabular}{|c|c|c|c|c|c|c|c|}
\hline Name & Age & Age Reference & Location & $\begin{array}{l}\text { Arial extent } \\
\left(\mathrm{km}^{2}\right)\end{array}$ & $\begin{array}{c}\text { Thickness } \\
\text { (m) }\end{array}$ & $\begin{array}{c}\text { Volume } \\
\left(\mathrm{km}^{3}\right)\end{array}$ & Reference \\
\hline Minto Inlet Fm. & 891-762 Ma & $\begin{array}{l}\text { (van Acken et al., } \\
\text { 2012; Rayner and } \\
\text { Rainbird, 2013) }\end{array}$ & $\begin{array}{l}\text { Amundsen Basin, NW } \\
\text { Canada }\end{array}$ & 78,000 & $\sim 300$ & 23,400 & $\begin{array}{l}\text { (Young, 1981; } \\
\text { Phaneuf, 1993) }\end{array}$ \\
\hline Kilian Fm. & 795-723Ма & $\begin{array}{l}\text { (Heaman et al., 1992; } \\
\text { Rayner and Rainbird, } \\
\text { 2013) }\end{array}$ & $\begin{array}{l}\text { Amundsen Basin, NW } \\
\text { Canada }\end{array}$ & 35,000 & $\sim 600$ & 21,000 & $\begin{array}{l}\text { (Jefferson, 1985; } \\
\text { Rainbird, 1991) }\end{array}$ \\
\hline Ten Stone Fm. & $>779 \mathrm{Ma}$ & $\begin{array}{l}\text { (Jefferson and } \\
\text { Parrish, 1989; } \\
\text { Heaman et al., 1992) }\end{array}$ & $\begin{array}{l}\text { Mackenzie Mountains, } \\
\text { NW Canada }\end{array}$ & 40,000 & 550 & 22,000 & $\begin{array}{l}\text { (Aitken, 1981; } \\
\text { Turner, 2009; Turner } \\
\text { and Long, 2012) }\end{array}$ \\
\hline Redstone River Fm. & 779-723 Ma & $\begin{array}{l}\text { (Jefferson and } \\
\text { Parrish, 1989; } \\
\text { Heaman et al., 1992) }\end{array}$ & $\begin{array}{l}\text { Mackenzie Mountains, } \\
\text { NW Canada }\end{array}$ & 40,000 & $0-1200$ & $<48,000$ & $\begin{array}{l}\text { (Jefferson, 1983; } \\
\text { Jefferson and Ruelle, } \\
\text { 1986) }\end{array}$ \\
\hline $\begin{array}{l}\text { Bitter Springs Fm., } \\
\text { Gillen Member }\end{array}$ & $\begin{array}{l}>802 \mathrm{Ma} \\
\text { estimated } \\
\sim 840 \mathrm{Ma}\end{array}$ & $\begin{array}{l}\text { (Fanning et al., 1986; } \\
\text { Walter et al., 2000) }\end{array}$ & $\begin{array}{l}\text { Amadeus Basin, } \\
\text { Central Australia }\end{array}$ & 158,000 & 1000 & 158,000 & (Lindsay, 1987) \\
\hline Browne Fm. & $>800$ & (Grey, 2005) & $\begin{array}{l}\text { Officer Basin, Central } \\
\text { Australia }\end{array}$ & 525,000 & 1000 & 525,000 & Grey et al., 2005 \\
\hline Skilogalee Fm. & $<777 \mathrm{Ma}$ & (Preiss, 2000) & $\begin{array}{l}\text { Adelaide foldbelt, } \\
\text { south Australia }\end{array}$ & 50,000 & $\sim 500$ & 25,000 & $\begin{array}{l}\text { (Preiss, 1993; Preiss, } \\
2000)\end{array}$ \\
\hline $\begin{array}{l}\text { Curdimurka Sub } \\
\text { Gp. }\end{array}$ & 802-777Ma & (Preiss, 2000) & $\begin{array}{l}\text { Adelaide foldbelt, } \\
\text { south Australia }\end{array}$ & 50,000 & 1000 & 50,000 & $\begin{array}{l}\text { (Rowlands et al., } \\
\text { 1980; Preiss, 1993) }\end{array}$ \\
\hline Duruchaus Fm. & $>720$ & (Frimmel et al., 1996) & $\begin{array}{l}\text { Damara orogen, } \\
\text { Namibia }\end{array}$ & 30,000 & 500 & 15,000 & $\begin{array}{l}\text { (Behr et al., 1983, } \\
\text { cited in Evans, 2006) }\end{array}$ \\
\hline Roan Supergroup & $883-765 \mathrm{Ma}$ & $\begin{array}{l}\text { (Key et al., 2001; } \\
\text { Armstrong et al., } \\
\text { 2005) }\end{array}$ & Central Africa & 50,000 & 500 & 25,000 & (Jackson et al., 2003) \\
\hline
\end{tabular}




\section{Carbon isotopes}

The carbon isotope record through the early Neoproterozoic is characterized by

a sustained positive $\delta^{13} \mathrm{C}_{\text {carb }}$ signature punctuated by large (up to $10 \%$ ) negative excursions (Halverson et al., 2010). Deposition of the Minto Inlet Formation $(>849 \pm 49$,

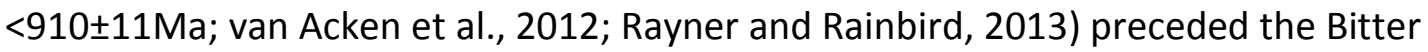
Springs anomaly, the first of several significant negative excursions (see discussions in section 3.2, above). Carbon isotopes from interstratified carbonates through the Minto Inlet Formation show the characteristic enrichment in $\delta^{13} \mathrm{C}$ with values hovering around 3-4\%o (Figure 25; Thomson et al., 2011). In the overlying Wynniatt Formation a 15\%o negative excursion in $\delta^{13} C_{\text {carb }}$ has been correlated with the Bitter Springs anomaly (Jones et al., 2010; Thomson et al., 2011). The negative excursion in the upper Kilian Formation reported here and previously discussed by Jones et al. (2010) is considered to be correlative with the globally recognized Islay anomaly which immediately precedes the first of at least 3 Neoproterozoic glacial episodes (e.g. Halverson, 2006).

Implied changes to the biogeochemical cycling of Sulphur and Carbon

The accumulation of dissolved sulphate in the ocean prior to the deposition of the mid-Neoproterozoic evaporites requires that the delivery of sulphate to the oceans exceeded the combined burial flux of both evaporite and pyrite. This in turn requires an increase in the rate of oxidative weathering of sulphur on the continents. Bartley and Kah (2004) suggest that an increase in $\delta^{13} C_{\text {carb }}$ in the late Mesoproterozoic was caused by an increase in $f_{\text {Corg }}$ driven by a reduction in suitable depositional environments for $\mathrm{C}_{\text {carb }}$ burial during supercontinent assembly. Since $\mathrm{C}_{\text {org }}$ does not sequester oxygen and 
$\mathrm{C}_{\text {carb }}$ does, an increase in $\mathrm{f}_{\text {corg }}$ would result in a net increase in $\mathrm{O}_{2}$ in the ocean, and by association, the concentration of $\mathrm{O}_{2}$ in the atmosphere. If the increase in $f_{\text {corg }}$ were sustained over 10 s to 100 s of million years, the feedback in atmospheric oxygen concentrations would result in an increase in the rate of oxidative weathering of continental rocks and therefore an increase in the delivery of sulphate to the ocean.

During the deposition of the mid-Neoproterozoic evaporites, the concentration of seawater sulphate was drawn down. Since sulphate is an important electron acceptor in anaerobic organic carbon remineralsation via bacterial sulphate reduction, a sustained decrease in sulphate availability would limit this process and therefore would be accompanied by an increase in $f_{\text {org. }}$. This is consistent with the elevated mean $\delta^{13} \mathrm{C}$ ( 5\%; Halverson et al., 2010) through the early Neoproterozoic. Sulphate reducing bacteria are also responsible for anaerobic methane oxidation, which prevents the build-up of methane hydrates in the sediment, another process which would be limited by a decrease in sulphate availability. The accumulation of large volumes of $\delta^{13} \mathrm{C}$ depleted methane hydrate in the sediment and its subsequent release is a plausible driver for the negative carbon isotope excursions of the Neoproterozoic (Bjerrum and Canfield, 2011).

\section{Connection to the Supercontinent Cycle}

The amalgamation of Rodinia during the late Mesoproterozoic would have reduced the extent of continental shelf suitable for the deposition and burial of carbonate carbon by limiting the coastline to the perimeter of the supercontinent. 
Burial of organic carbon, which occurs primarily in deep, anoxic waters, would have continued, unimpeded, in the deep ocean eventually resulting, first in the accumulation of atmospheric oxygen, followed by an increase in the delivery of sulphate to the oceans via enhanced weathering. The development of large and shallow intracratonic basins during the stable craton and early rifting stages of the supercontinent cycle (Figure 32) generated favourable conditions for the precipitation and burial of evaporite minerals. The coincident migration of Rodinia across the equator through the early-mid Neoproterozoic (Li et al., 2008; Swanson-Hysell et al., 2012) would have placed those intracratonic basins in arid climate zones (Figure 32; Evans, 2006), resulting in the deposition of huge volumes of evaporite minerals, effectively drawing down the concentration of seawater sulphate and allowing for the build-up of methane hydrates within marine substrates. 


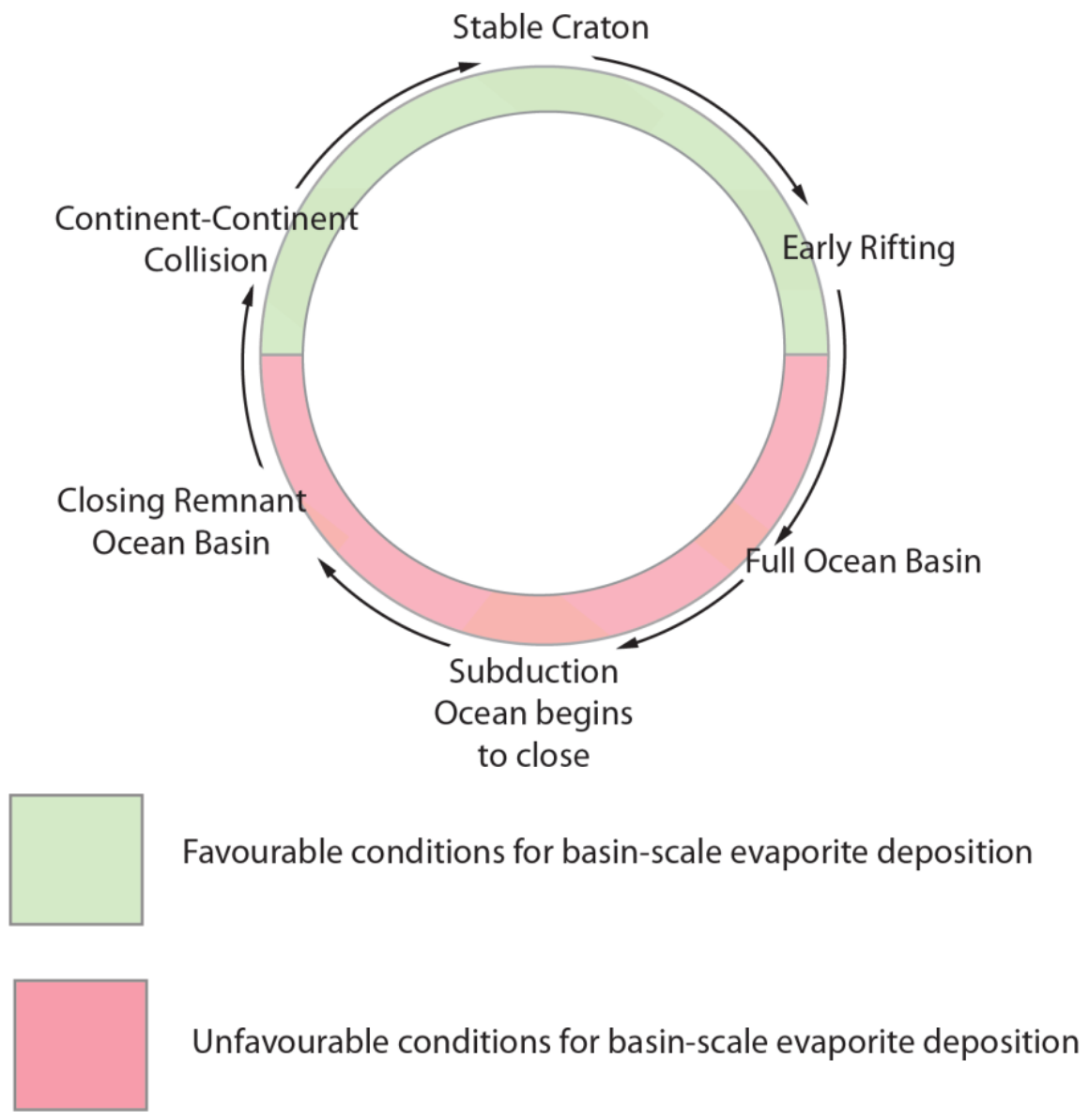

Figure 32: Super continent cycle and its connection with basin-scale evaporite deposition. Modified from Warren et al. (2010) 


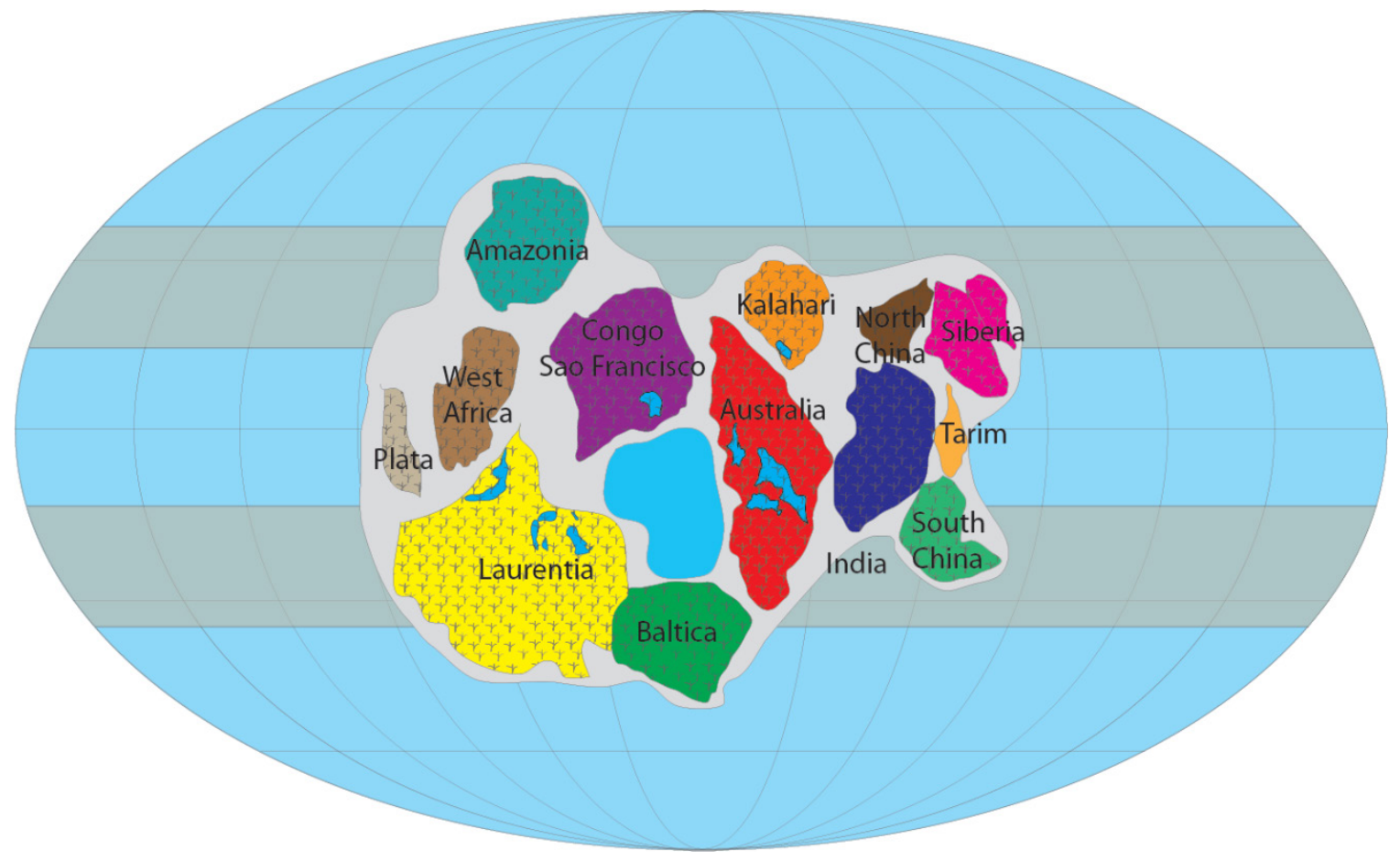

Figure 33: Rodinia reconstruction after Evans (2009) at $\sim 780$ Ma showing the locations of arid climate belts (grey) and major intracratonic evaporite basins (see Table 4, above). The migration of Rodinia across equatorial latitudes through the middle Neoproterozoic was a driver for evaporite deposition in each of the respective basins as they crossed the arid climate belts.

The proposed connection between the supercontinent cycle and seawater chemistry is consistent with studies of secular variability in major ion concentrations and with supercontinent cycling through the Phanerozoic (Holser, 1984; Lowenstein et al., 2003; Condie, 2005). Specifically, the concentration of seawater sulphate $\left(\left[\mathrm{SO}_{4}{ }^{2-}\right]\right)$ is highest during continent-continent collision and stable craton phases while the concentration of seawater calcium $\left(\left[\mathrm{Ca}^{2+}\right]\right)$ is greatest during full ocean basin and subduction phases (Figure 33; Lowenstein et al., 2003). The secular $\left[\mathrm{SO}_{4}{ }^{2-}\right]$ trend can be explained by the processes outlined above while the $\left[\mathrm{Ca}^{2+}\right]$ trend is thought to be 
related to seafloor spreading rates and the flux of hydrothermal $\mathrm{CaCl}_{2}$ brines at midocean ridges (Lowenstein et al., 2003), which are maximized during the dispersion phase of the supercontinent cycle. If the Phanerozoic trends are applied to the Neoproterozoic, it follows that the Minto Inlet Formation would have been deposited during the stable craton phase while $\left[\mathrm{SO}_{4}{ }^{2-}\right]$ was maximized while the Kilian Formation would have been deposited during the early rifting phase when $\left[\mathrm{SO}_{4}{ }^{2-}\right]$ was greatly reduced. This is consistent with evidence for plume-related uplift and early volcanism in the Kilian Formation (see chapter 2), which are interpreted to reflect the onset of rifting that accompanied the break-up of Rodinia.

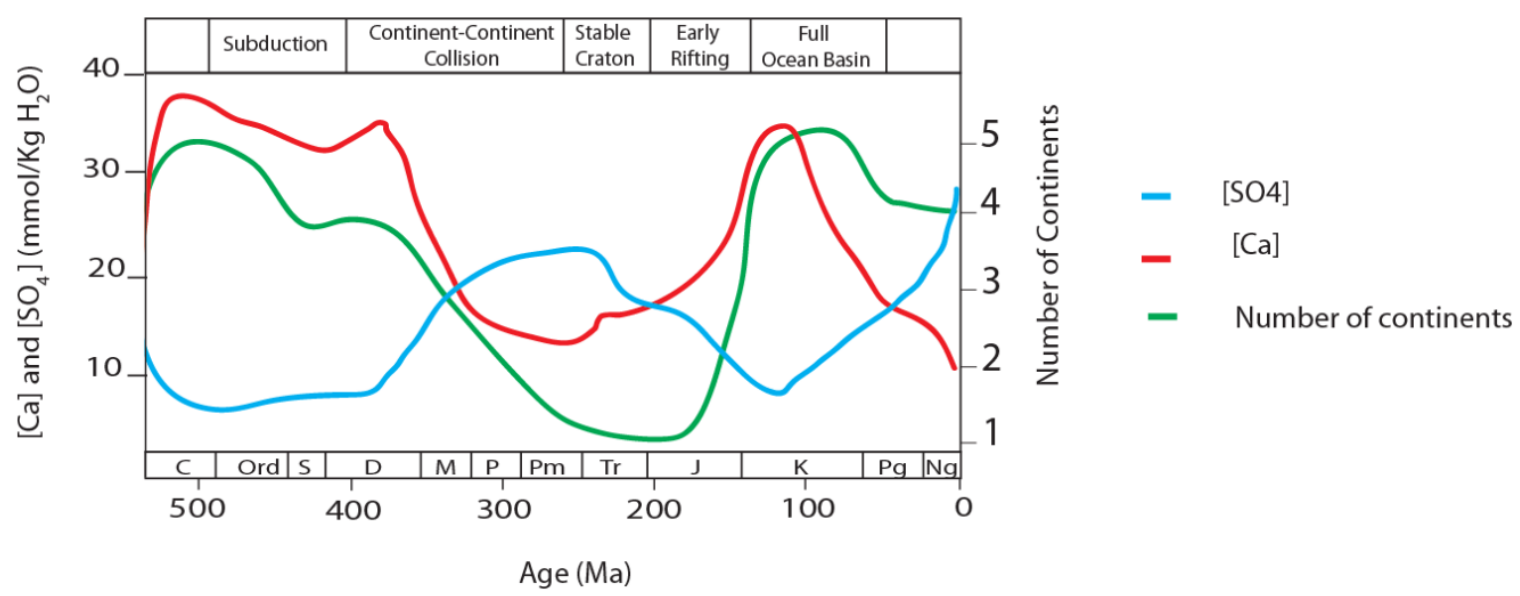

Figure 34: Plot showing the negative correlation between $\left[\mathrm{Ca}^{2+}\right]$ (red) and $\left[\mathrm{SO}_{4}{ }^{2-}\right]$ (blue) through Phanerozoic time (after Lowenstein et al., 2003). The number of continents curve (green) is modified from Condie (2005). 


\section{Chapter 6: Conclusions}

The Minto Inlet Formation is subdivided into three regionally extensive members; the lower evaporite, carbonate and upper evaporite members. The lower evaporite member is dominated by a mosaic of sabkha and salina deposits interpreted to have formed in an evaporitic mudflat setting. The carbonate member comprises inter-tidal to sub-tidal marine limestone and dolostone and reflects a rise in relative sea level from the underlying lower evaporite member. The upper evaporite member is dominated by cyclically alternating medium to thick accumulations of mudstone and gypsum/anhydrite, which are interpreted as basinal evaporites or saltern deposits.

Sequence stratigraphic analysis of the Kilian Formation reveals 4 depositional sequences B5V-I to B5-IV, each of which can be further subdivided into depositional systems tracts (LST, TST, HST and FSST). The organization of the sequences within the Kilian Formation reflects two stages of deposition; the three lowermost sequences, B5-I to B5-III outline a repetitive alternation between a supratidal, siliciclastic and evaporitedominated depositional environment and an inter- to sub-tidal, carbonate-dominated, depositional environment on a steadily subsiding ramp. The second stage of deposition is characterized by a consistent basinward progradation of intertidal carbonate facies and supratidal evaporite facies, which resulted in emergence and erosion prior to the deposition of the overlying fluvial deposits of the Kuujjua Formation. The contact between the Kilian and Kuujjua formations is marked by an erosional unconformity, 
which is overlain by volcanogenic sandstones. These are interpreted to reflect the early stages of Franklin LIP related volcanism and the onset of rifting at this location.

Significantly different sulphur isotope signatures are recorded in the Minto Inlet and the Kilian formations. The $\delta^{34} \mathrm{~S}$ values from the Minto Inlet Formation exhibit limited variability and are generally lower in magnitude than modern seawater. These results are contrasted with more highly variable and significantly enriched (with respect to modern seawater) $\delta^{34} S$ values from the Kilian Formation. Furthermore the $\Delta^{33} S$ values from the Minto Inlet Formation are positive while $\Delta^{33} S$ values from the Kilian Formation are exclusively negative. Steady and non-steady state modelling suggests that differences in the sulphur isotope signatures of the Minto Inlet and Kilian formations were caused by a temporary reorganization of the sulphur cycle. The sulphur isotopes of the Minto Inlet Formation reflect high concentrations of seawater sulphate and a low pyrite burial fraction ( 0.3), similar to the conditions of the middle Phanerozoic. Sulphur isotope trends in the Kilian Formation reflect low seawater sulphate concentrations and a high pyrite burial fraction ( 1) more typical of the Precambrian. These results require that a substantial decrease in the size of the marine sulphate reservoir and a reorganization of the sulphur flux out of the ocean occurred during deposition of the intervening Wynniatt Formation.

Diminished sulphate concentrations in the global oceans would have resulted in an increase in $f_{\text {org }}$ and in the preservation and build-up of methane hydrates in the substrate. This is consistent with the enriched mean $\delta^{13} \mathrm{C}_{\text {carb }}$ signature through the 
Minto Inlet, Wynniatt and Kilian formations, which is punctuated by two large negative excursions in the upper Wynniatt Formation and upper Kilian Formation respectively. 


\section{References}

Aitken, J., 1981. Stratigraphy and sedimentology of the Upper Proterozoic Little Dal Group, Mackenzie Mountains, Northwest Territories. Proterozoic Basins of Canada. Geological Survey of Canada, Paper: 81-10.

Alsharhan, A., Kendall, C.S.C., 1994. Depositional setting of the Upper Jurassic Hith anhydrite of the Arabian Gulf: an analog to Holocene evaporites of the United Arab Emirates and Lake MacLeod of Western Australia. AAPG Bulletin (American Association of Petroleum Geologists);(United States), 78(7).

Armstrong, R., Master, S., Robb, L., 2005. Geochronology of the Nchanga Granite, and constraints on the maximum age of the Katanga Supergroup, Zambian Copperbelt. Journal of African Earth Sciences, 42(1): 32-40.

Arthur, M.A., Sageman, B.B., 1994. Marine shales: depositional mechanisms and environments of ancient deposits. Annual Review of Earth and Planetary Sciences, 22: 499-551.

Asmerom, Y., Jacobsen, S.B., Knoll, A.H., Butterfield, N.J., Swett, K., 1991. Strontium isotopic variations of Neoproterozoic seawater: implications for crustal evolution. Geochimica et Cosmochimica Acta, 55(10): 2883-2894.

Ault, W.U., Kulp, J., 1959. Isotopic geochemistry of sulphur. Geochimica et Cosmochimica Acta, 16(4): 201-235.

Baragar, W., 1976. The Natkusiak Basalts, Victoria Island, District of Franklin. Report of Activities: Geological Survey of Canada Paper: 347-352.

Baragar, W.R.A., Donaldson, J.A., 1973. Coppermine and Dismal Lakes map areas. Geological Survey of Canada Paper, 71(39): 20.

Bartley, J.K., Kah, L.C., 2004. Marine carbon reservoir, Corg-Ccarb coupling, and the evolution of the Proterozoic carbon cycle. Geology, 32(2): 129-132.

Bathurst, R.G., 1972. Carbonate sediments and their diagenesis, 12. Elsevier Science.

Behr, H.J., Ahrendt, H., Porada, H., Rohrs, J., Weber, K., 1983. In: Miller, R.M. (Ed.), Evolution of the Damara Orogen of South West Africa/Namibia Geological Society of South Africa, Pretoria, pp. 1-20. 
Berner, R., 2005. The carbon and sulfur cycles and atmospheric oxygen from middle Permian to middle Triassic. Geochimica et Cosmochimica Acta, 69(13): 32113217.

Berner, R.A., 1987. Models for carbon and sulfur cycles and atmospheric oxygen; application to Paleozoic geologic history. American Journal of Science, 287(3): 177-196.

Berner, R.A., 1989. Biogeochemical cycles of carbon and sulfur and their effect on atmospheric oxygen over Phanerozoic time. Palaeogeography, Palaeoclimatology, Palaeoecology, 75(1-2): 97-122.

Bjerrum, C.J., Canfield, D.E., 2011. Towards a quantitative understanding of the late Neoproterozoic carbon cycle. Proceedings of the National Academy of Sciences, 108(14): 5542-5547.

Boggs, S., 2009. Petrology of sedimentary rocks. Cambridge University Press.

Brasier, M., Shields, G., 2000. Neoproterozoic chemostratigraphy and correlation of the Port Askaig glaciation, Dalradian Supergroup of Scotland. Journal of the Geological Society, 157(5): 909-914.

Briggs, L.I., 1958. Evaporite facies. Journal of Sedimentary Research, 28(1): 46-56.

Bristow, T.F., Kennedy, M.J., 2008. Carbon isotope excursions and the oxidant budget of the Ediacaran atmosphere and ocean. Geology, 36(11): 863-866.

Burdett, W.J., Arthur, A.M., Richardson, M., 1989. A Neogene seawater sulfur isotope age curve from calcareous pelagic microfossils. Earth and Planetary Science Letters, 94(3): 189-198.

Burns, S., Matter, A., 1993. Carbon isotopic record of the latest Proterozoic from Oman. Eclogae Geologicae Helvetiae, 86(2): 595-607.

Campbell, F.H.A., 1985. Stratigraphy of the upper part of the Rae Group, Johansen Bay area, northern Coronation Gulf, District of Franklin. Current Research, Part A: Geological Survey of Canada Paper 85-1A: 693-696.

Canfield, D., 2001. Biogeochemistry of sulfur isotopes. Reviews in Mineralogy and Geochemistry, 43(1): 607-636. 
Canfield, D.E., 2004. The evolution of the Earth surface sulfur reservoir. American Journal of Science, 304(10): 839-861.

Canfield, D.E., Farquhar, J., 2009. Animal evolution, bioturbation, and the sulfate concentration of the oceans. Proceedings of the National Academy of Sciences, 106(20): 8123-8127.

Cant, D.J., Walker, R.G., 1976. Development of a braided-fluvial facies model for the Devonian Battery Point Sandstone, Quebec. Canadian Journal of Earth Sciences, 13(1): 102-119.

Catuneanu, O., 2006. Principles of sequence stratigraphy. Elsevier. Amsterdam, 375p.

Catuneanu, O. et al., 2011. Sequence stratigraphy: methodology and nomenclature. Newsletters on Stratigraphy, 44(3): 173-245.

Condie, K.C., 2005. Earth as an evolving planetary system. Academic Press.

Cook, D.G., Aitken, J.D., 1969. Erly Lake (97A). Geological Survey of Canada.

Derry, L.A., 2010. A burial diagenesis origin for the Ediacaran Shuram-Wonoka carbon isotope anomaly. Earth and Planetary Science Letters, 294(1): 152-162.

Elliott, L., Warren, J., 1989. Stratigraphy and depositional environment of lower San Andres Formation in subsurface and equivalent outcrops; Chaves, Lincoln, and Roosevelt counties, New Mexico. AAPG Bulletin, 73(11): 1307-1325.

Embry, A., 2009. Practical sequence stratigraphy. Canadian Society of Petroleum Geologists, 81.

Embry, A.F., 2002. Transgressive-regressive (TR) sequence stratigraphy, Gulf Coast SEPM Conference Proceedings, Houston. SEPM, pp. 151-172.

Evans, D.A.D., 2006. Proterozoic low orbital obliquity and axial-dipolar geomagnetic field from evaporite palaeolatitudes. Nature, 444(7115): 51-55.

Fanning, C.M., Ludwig, K.R., Forbes, B.G., Preiss, W.V., 1986. Single and multiple grain analyses for the early Adeladian Rook Tuff, Willouran Ranges, South Australia, Geological Society of Australia Convention. 
Farquhar, J., Bao, H., Thiemens, M., 2000. Atmospheric influence of Earth's earliest sulfur cycle. Science, 289(5480): 756-758.

Farquhar, J., Wing, B.A., 2003. Multiple sulfur isotopes and the evolution of the atmosphere. Earth and Planetary Science Letters, 213(1-2): 1-13.

Fortier, Y.O., McNair, A.H., Thorsteisson, R., 1954. Geology and petroleum possibilities in the Canadian Arctic Islands. American Association of Petroleum Geologists Bulletin, 38: 2075-2190.

Frimmel, H.E., Klötzli, U.S., Siegfried, P.R., 1996. New Pb-Pb single zircon age constraints on the timing of Neoproterozoic glaciation and continental break-up in Namibia. The Journal of Geology: 459-469.

Garrels, R.M., Lerman, A., 1981. Phanerozoic cycles of sedimentary carbon and sulfur. Proceedings of the National Academy of Sciences, 78(8): 4652.

Garrels, R.M., Lerman, A., 1984. Coupling of the sedimentary sulfur and carbon cycles; an improved model. American Journal of Science, 284(9): 989-1007.

Gellatly, A.M., Lyons, T.W., 2005. Trace sulfate in mid-Proterozoic carbonates and the sulfur isotope record of biospheric evolution. Geochimica et Cosmochimica Acta, 69(15): 3813-3829.

Grey, K., 2005. Lithostratigraphic nomenclature of the Officer Basin and correlative parts of the Paterson Orogen, Western Australia. Geological Survey of Western Australia.

Halverson, G., 2006. A Neoproterozoic chronology. Neoproterozoic Geobiology and Paleobiology: 231-271.

Halverson, G., Hurtgen, M., 2007. Ediacaran growth of the marine sulfate reservoir. Earth and Planetary Science Letters, 263(1-2): 32-44.

Halverson, G.P., Hurtgen, M.T., Porter, S.M., Collins, A.S., 2009. Chapter 10 Neoproterozoic-Cambrian Biogeochemical Evolution. 16: 351-365.

Halverson, G.P., Wade, B.P., Hurtgen, M.T., Barovich, K.M., 2010. Neoproterozoic chemostratigraphy. Precambrian Research, 182(4): 337-350. 
Hardie, L.A., Lowenstein, T.K., Spencer, R.J., 1985. The problem of distinguishing between primary and secondary features in evaporites, Sixth international symposium on salt. Salt Institute Alexandria, pp. 11-39.

Hayes, J.M., Strauss, H., Kaufman, A.J., 1999. The abundance of $13 \mathrm{C}$ in marine organic matter and isotopic fractionation in the global biogeochemical cycle of carbon during the past $800 \mathrm{Ma}$. Chemical Geology, 161(1): 103-125.

Heaman, L., LeCheminant, A., Rainbird, R., 1992. Nature and timing of Franklin igneous events, Canada: implications for a Late Proterozoic mantle plume and the breakup of Laurentia. Earth and Planetary Science Letters, 109(1): 117-131.

Hill, A., Walter, M., 2000. Mid-Neoproterozoic ( 830-750 Ma) isotope stratigraphy of Australia and global correlation. Precambrian Research, 100(1): 181-211.

Holser, W., 1984. Gradual and abrupt shifts in ocean chemistry during Phanerozoic time, Patterns of change in Earth evolution. Springer, pp. 123-143.

Holser, W., Schidlowski, M., Mackenzie, F., Maynard, J., 1988. Geochemical cycles of carbon and sulfur. Chemical Cycles in the Evolution of the Earth: 105-173.

Hunt, D., Tucker, M.E., 1992. Stranded parasequences and the forced regressive wedge systems tract: deposition during base-level'fall. Sedimentary Geology, 81(1): 1-9.

Hurtgen, M.T., Arthur, M.A., Halverson, G.P., 2005. Neoproterozoic sulfur isotopes, the evolution of microbial sulfur species, and the burial efficiency of sulfide as sedimentary pyrite. Geology, 33(1): 41.

Hurtgen, M.T., Arthur, M.A., Suits, N.S., Kaufman, A.J., 2002. The sulfur isotopic composition of Neoproterozoic seawater sulfate: implications for a snowball Earth? Earth and Planetary Science Letters, 203(1): 413-429.

Hurtgen, M.T., Halverson, G.P., Arthur, M.A., Hoffman, P.F., 2006. Sulfur cycling in the aftermath of a 635-Ma snowball glaciation: Evidence for a syn-glacial sulfidic deep ocean. Earth and Planetary Science Letters, 245(3): 551-570.

Hurtgen, M.T., Pruss, S.B., Knoll, A.H., 2009. Evaluating the relationship between the carbon and sulfur cycles in the later Cambrian ocean: an example from the Port au Port Group, western Newfoundland, Canada. Earth and Planetary Science Letters, 281(3): 288-297. 
Jackson, M., Warin, O., Woad, G., Hudec, M., 2003. Neoproterozoic allochthonous salt tectonics during the Lufilian orogeny in the Katangan Copperbelt, central Africa. Geological Society of America Bulletin, 115(3): 314-330.

James, N.P., Narbonne, G.M., Sherman, A.G., 1998. Molar-tooth carbonates: shallow subtidal facies of the Mid-to Late Proterozoic. Journal of Sedimentary Research, 68(5).

Jefferson, C., 1983. The Upper Proterozoic Redstone Copper Belt, Mackenzie Mountains, NWT Ph. D, thesis, The University of Western Ontario, London, Ont.

Jefferson, C., 1985. Uppermost Shaler Group and its contact with the Natkusiak Basalts, Victoria Island, District of Franklin. Current Research Part A: Geological Survey of Canada Paper: 103-110.

Jefferson, C., Nelson, W., Kirkham, R., Reedman, J., Scoates, R., 1985. Geology and copper occurrences of the Natkusiak basalts, Victoria Island, District of Franklin. Current Research Part A: Geological Survey of Canada Paper: 203-214.

Jefferson, C., Parrish, R., 1989. Late Proterozoic stratigraphy, U-Pb zircon ages, and rift tectonics, Mackenzie Mountains, northwestern Canada. Canadian Journal of Earth Sciences, 26(9): 1784-1801.

Jefferson, C.W., Ruelle, J.C., 1986. The Late Proterozoic Redstone Copper Belt, Mackenzie Mountains, Northwest Territories. Mineral Deposits of Northern Cordillera. Special Volume, 37: 154-168.

Johnston, D., Farquhar, J., Canfield, D., 2007. Sulfur isotope insights into microbial sulfate reduction: When microbes meet models. Geochimica et Cosmochimica Acta, 71(16): 3929-3947.

Johnston, D.T., 2011. Multiple sulfur isotopes and the evolution of Earth's surface sulfur cycle. Earth-Science Reviews, 106(1-2): 161-183.

Johnston, D.T. et al., 2005a. Multiple sulfur isotope fractionations in biological systems: a case study with sulfate reducers and sulfur disproportionators. American Journal of Science, 305(6-8): 645-660.

Johnston, D.T. et al., 2005b. Active microbial sulfur disproportionation in the Mesoproterozoic. Science, 310(5753): 1477-1479. 
Jones, D.S., Maloof, A.C., Hurtgen, M.T., Rainbird, R.H., Schrag, D.P., 2010. Regional and global chemostratigraphic correlation of the early Neoproterozoic Shaler Supergroup, Victoria Island, Northwestern Canada. Precambrian Research, 181(1-4): 43-63.

Kah, L.C., Lyons, T.W., Frank, T.D., 2004. Low marine sulphate and protracted oxygenation of the Proterozoic biosphere. Nature, 431(7010): 834-838.

Kampschulte, A., Bruckschen, P., Strauss, H., 2001. The sulphur isotopic composition of trace sulphates in Carboniferous brachiopods: implications for coeval seawater, correlation with other geochemical cycles and isotope stratigraphy. Chemical Geology, 175(1): 149-173.

Key, R. et al., 2001. The western arm of the Lufilian Arc in NW Zambia and its potential for copper mineralization. Journal of African Earth Sciences, 33(3): 503-528.

Kirschvink, J.L., 1992. Late Proterozoic low-latitude global glaciation: the snowball Earth. In: Schopf, J.W., Klein, C. (Eds.), The Proterozoic Biosphere. Cambridge University Press, New York, pp. 51-52.

Knoll, A., Hayes, J., Kaufman, A., Swett, K., Lambert, I., 1986. Secular variation in carbon isotope ratios from Upper Proterozoic successions of Svalbard and East Greenland.

Kump, L.R. et al., 2011. Isotopic evidence for massive oxidation of organic matter following the great oxidation event. Science, 334(6063): 1694-1696.

Leavitt, W.D., Halevy, I., Bradley, A.S., Johnston, D.T., 2013. Influence of sulfate reduction rates on the Phanerozoic sulfur isotope record. Proceedings of the National Academy of Sciences.

Lewis, D.W., 1984. Practical sedimentology. Hutchinson Ross, 229 pp.

Li, Z. et al., 2008. Assembly, configuration, and break-up history of Rodinia: a synthesis. Precambrian Research, 160(1): 179-210.

Lindsay, J.F., 1987. Upper Proterozoic evaporites in the Amadeus basin, central Australia, and their role in basin tectonics. Geological Society of America Bulletin, 99(6): 852-865. 
Logan, B.W., Rezak, R., Ginsburg, R.N., 1964. Classification and environmental significance of algal stromatolites. The Journal of Geology: 68-83.

Long, D.G.F., Rainbird, R.H., Turner, E.C., MacNaughton, R.B., 2008. Early Neoproterozoic strata (Sequence B) of mainland northern Canada and Victoria and Banks islands: a contribution to the Geological Atlas of the Northern Canadian Mainland Sedimentary Basin

Geological Survey of Canada, Open File 5700: 24 p.

Loucks, R.G., Sarg, J.F., 1993. Carbonate equence stratigraphy, recent development and applications. American Association of Petroleum Geoligists Memoir(57): 545.

Lowenstein, T.K., Hardie, L.A., Timofeeff, M.N., Demicco, R.V., 2003. Secular variation in seawater chemistry and the origin of calcium chloride basinal brines. Geology, 31(10): 857-860.

Lyons, T.W., Walter, L.M., Gellatly, A.M., Martini, A.M., Blake, R.E., 2004. Sites of anomalous organic remineralization in the carbonate sediments of South Florida, USA: The sulfur cycle and carbonate-associated sulfate. Geological Society of America Special Papers: 161-176.

Macdonald, F.A. et al., 2010. Calibrating the Cryogenian. Science, 327(5970): 1241-1243.

Marenco, P.J., Corsetti, F.A., Kaufman, A.J., Bottjer, D.J., 2008. Environmental and diagenetic variations in carbonate associated sulfate: An investigation of CAS in the Lower Triassic of the western USA. Geochimica et Cosmochimica Acta, 72(6): 1570-1582.

McKirdy, D.M. et al., 2001. A chemostratigraphic overview of the late Cryogenian interglacial sequence in the Adelaide Fold-Thrust Belt, South Australia. Precambrian Research, 106(1-2): 149-186.

Murray, R., 1964. Origin and diagenesis of gypsum and anhydrite. Journal of Sedimentary Research, 34(3): 512-523.

O'Neill, J.J., 1924. The Geology of the Arctic Coast of Canada: West of the Kent Peninsula, Report of the Canadian Arctic Expedition 1913-1918. FA Aeland, King's printer, Ottawa, pp. 107.

Park, J.K., 1994. Palaeomagnetic constraints on the position of Laurentia from middle Neoproterozoic to Early Cambrian times. Precambrian Research, 69(1): 95-112. 
Pell, S.D., McKirdy, D.M., Jansyn, J., Jenkins, R.J.F., 1993. Ediacaran carbon isotope stratigraphy of South Australia An initial study. Trans. Royal Soc. S. Austral. , 117: 153- 161.

Pettijohn, F., Potter, P., Siever, R., 1975. Sedimentary Rocks Harper and Row. New York: 628.

Petty, A.J., 1995. Ferry Lake, Rodessa, and Punta Gorda Anhydrite bed correlation, lower cretaceous, offshore eastern Gulf of Mexico. AAPG Bulletin, 79.

Phaneuf, S., 1993. Stratigraphy and sedimentology of the Neoproterozoic Minto Inlet Formation, Minto Inlier, Victoria Island, Northwest Territories. , University of Ottawa, Ottawa.

Plint, A.G., Nummedal, D., 2000. The falling stage systems tract: recognition and importance in sequence stratigraphic analysis. Geological Society, London, Special Publications, 172(1): 1-17.

Posamentier, H., Jervey, M., Vail, P., 1988. Eustatic controls on clastic deposition Iconceptual framework. Sea-Level Changes: An Integrated Approach: SEPM, Special Publication, 42: 109-124.

Posamentier, H.W., Allen, G.P., 1999. Siliciclastic sequence stratigraphy: concepts and applications. SEPM (Society for Sedimentary Geology).

Preiss, W., 2000. The Adelaide Geosyncline of South Australia and its significance in Neoproterozoic continental reconstruction. Precambrian Research, 100(1): 2163.

Preiss, W.V., 1993. The Precambrian. In: Drexel, J.F., Preiss, W.V., Parker, A.J. (Eds.), The geology of South Australia. South Australia Geological Survey, Adelaide.

Raab, M., Spiro, B., 1991. Sulfur isotopic variations during seawater evaporation with fractional crystallization. Chemical Geology: Isotope Geoscience section, 86(4): 323-333.

Rainbird, R., Cawood, P., Gehrels, G., 2012. The great Grenvillian sedimentation episode: record of supercontinent Rodinia's assembly. Tectonics of sedimentary basins: recent advances: 583-601. 
Rainbird, R.H., 1991. Stratigraphy, sedimentology and tectonic setting of the upper Shaler Group, Victoria Island, Northwest Territories, University of Western Ontario, London, Ontario.

Rainbird, R.H., 1993. The sedimentary record of mantle plume uplift preceding eruption of the Neoproterozoic Natkusiak flood basalt. The Journal of Geology: 305-318.

Rainbird, R.H., Hearnan, L.M., Young, G., 1992. Sampling Laurentia: Detrital zircon geochronology offers evidence for an extensive Neoproterozoic river system originating from the Grenville orogen. Geology, 20(4): 351-354.

Rainbird, R.H., Jefferson, C.W., Hildebrand, R.S., Worth, J.K., 1994. The Shaler Supergroup and revision of Neoproterozoic stratigraphy in Amundsen Basin, Northwest Territories. Current Research, Part A: Geological Survey of Canada, Paper: 61-70.

Rainbird, R.H., Jefferson, C.W., Young, G.M., 1996. The early Neoproterozoic sedimentary Succession B of northwestern Laurentia: Correlations and paleogeographic significance. Geological Society of America Bulletin, 108(4): 454470.

Rainbird, R.H. et al., 1997. Pan-continental river system draining Grenville Orogen recorded by $\mathrm{U}-\mathrm{Pb}$ and $\mathrm{Sm}-\mathrm{Nd}$ geochronology of Neoproterozoic quartzarenites and mudrocks, northwestern Canada. The Journal of Geology: 1-17.

Rayner, N.M., Rainbird, R.H., 2013. U-Pb geochronology of the Shaler Supergroup, Victoria Island, NW Canada: 2009-2013. Geological Survey of Canada Open File, 7419.

Rosman, K.J.R., Taylor, P.D.P., 1998. Isotopic Compositions of the Elements. Pure and Applied Chemistry, 70(1): 217-235.

Rothman, D.H., Hayes, J.M., Summons, R.E., 2003. Dynamics of the Neoproterozoic carbon cycle. Proceedings of the National Academy of Sciences, 100(14): 81248129.

Rowlands, N., Blight, P., Jarvis, D., Von Der Borch, C., 1980. Sabkha and playa environments in late Proterozoic grabens, Willouran Ranges, South Australia. Journal of the Geological Society of Australia, 27(1-2): 55-68. 
Schrag, D.P., Higgins, J.A., Macdonald, F.A., Johnston, D.T., 2013. Authigenic Carbonate and the History of the Global Carbon Cycle. Science, 339(6119): 540-543.

Schreiber, B.C., Tabakh, M.E., 2000. Deposition and early alteration of evaporites. Sedimentology, 47(s1): 215-238.

Sepkoski, J.J., Jr., 1982. Flat-Pebble Conglomerates, Storm Deposits, and the Cambrian Bottom Fauna. In: Einsele, G., Seilacher, A. (Eds.), Cyclic and Event Stratification. Springer Berlin Heidelberg, pp. 371-385.

Sim, M.S., Bosak, T., Ono, S., 2011a. Large sulfur isotope fractionation does not require disproportionation. Science, 333(6038): 74-77.

Sim, M.S., Ono, S., Donovan, K., Templer, S.P., Bosak, T., 2011b. Effect of electron donors on the fractionation of sulfur isotopes by a marine Desulfovibrio $\mathrm{sp}$. Geochimica et Cosmochimica Acta, 75(15): 4244-4259.

Sonnenfeld, P., 1979. Brines and evaporites. Geoscience Canada, 6(2).

Staudt, W.J., Schoonen, M.A.A., 1995. Sulfate incorporation into sedimentary carbonates, ACS Symposium Series. ACS Publications, pp. 332-347.

Strauss, H., 1997. The isotopic composition of sedimentary sulfur through time. Palaeogeography, Palaeoclimatology, Palaeoecology, 132(1): 97-118.

Swanson-Hysell, N.L. et al., 2012. Constraints on Neoproterozoic paleogeography and Paleozoic orogenesis from paleomagnetic records of the Bitter Springs Formation, Amadeus Basin, central Australia. American Journal of Science, 312(8): 817-884.

Thode, H., Monster, J., Dunford, H., 1961. Sulphur isotope geochemistry. Geochimica et Cosmochimica Acta, 25(3): 159-174.

Thode, H., Rees, C., 1971. Measurement of sulphur concentrations and the isotope ratios 33S/32S, 34S/32S and 36S/32S in Apollo 12 samples. Earth and Planetary Science Letters, 12(4): 434-438.

Thomson, D., Rainbird, R.H., Krapez, B., 2014. Sequence stratigraphy of the Neoproterozoic (Tonian-Cryogenian) Amundsen Basin prior to Supercontinent (Rodinia) breakup. In press. 
Thomson, D.M., Rainbird, R.H., Krapez, B., 2011. Preliminary sequence stratigraphy and $\delta 13 \mathrm{C}$ data from the Minto Inlet and Wynniatt formations, Shaler Supergroup, western Minto Inlier, Victoria Island, NWT., GAC - MAC - SEG - SGA Joint Annual Meeting, Ottawa.

Thorsteinsson, R., Tozer, E.T., 1962. Banks, Victoria, and Stefansson Islands, Arctic Archipelago. Dept. of Mines and Technical Surveys.

Turner, E.C., 2009. Lithostratigraphy and stable isotope values of the early Neoproterozoic Gypsum formation (Little Dal Group, Mackenzie Mountains Supergroup), NWT. 2009-002, Northwest Territories Geoscience Office.

Turner, E.C., Long, D.G.F., 2012. Formal definition of the Neoproterozoic Mackenzie Mountains Supergroup (Northwest Territiories), and formal stratigraphic nomenclature for its carbonate and evaporite formations. Geological Survey of Canada Open File, 7112: 57.

Vail, P.R., Mitchum Jr, R., Thompson III, S., 1977. Seismic Stratigraphy and Global Changes of Sea Level: Part 4. Global Cycles of Relative Changes of Sea Level.: Section 2. Application of Seismic Reflection Configuration to Stratigraphic Interpretation.

van Acken, D., Thomson, D., Rainbird, R.H., Creaser, R.A., 2012. Rhenium-Osmium dating of black shales from the Neoproterozoic Shaler Supergroup, Victoria Island, Canada, V. M. Goldschmidt Montreal.

Van Wagoner, J. et al., 1988. An overview of the fundamentals of sequence stratigraphy and key definitions. In: Wilgus, C.K. et al. (Eds.), Sea Level Changes - An Integrated Approach. SEPM Special Publication, pp. 39-45.

Van Wagoner, J.C., Mitchum, R.M., Campion, K.M., Rahmanian, V.D., 1990. Siliciclastic sequence stratigraphy in well logs, cores and outcrops. American Association of Petroleum Geoligists, Methods (7): 45 pp.

Veizer, J. et al., 1999. 87Sr/86Sr, $\delta 13 \mathrm{C}$ and $\delta 180$ evolution of Phanerozoic seawater. Chemical Geology, 161(1): 59-88.

Walter, M., Veevers, J., Calver, C., Gorjan, P., Hill, A., 2000. Dating the 840-544 Ma Neoproterozoic interval by isotopes of strontium, carbon, and sulfur in seawater, and some interpretative models. Precambrian Research, 100(1): 371-433. 
Warren, J., 1999. Evaporites: their evolution and economics, 438. Blackwell Science Oxford.

Warren, J.K., 1991. Sulfate Dominated Sea-Marginal and Platform Evaporative Settings:: Sabkhas and Salinas, Mudflats and Salterns. Developments in Sedimentology, 50: 69-187.

Warren, J.K., 2010. Evaporites through time: Tectonic, climatic and eustatic controls in marine and nonmarine deposits. Earth-Science Reviews, 98(3): 217-268.

Warren, J.K., Kendall, C.G.S.C., 1985. Comparison of sequences formed in marine sabkha (subaerial) and salina (subaqueous) settings--modern and ancient. AAPG Bulletin, 69(6): 1013-1023.

Washburn, A.L., 1947. Reconnaissance geology of portions of Victoria Island and adjacent regions. Geological Society of America Memoir, 22.

Young, G., Jefferson, C., 1975. Late Precambrian shallow water deposits, Banks and Victoria Islands, Arctic Archipelago. Canadian Journal of Earth Sciences, 12(10): 1734-1748.

Young, G., Jefferson, C., Delaney, G., Yeo, G., 1979. Middle and late Proterozoic evolution of the northern Canadian Cordillera and Shield. Geology, 7(3): 125-128.

Young, G.M., 1974. Stratigraphy, paleocurrents and stromatolites of Hadrynian (Upper Precambrian) rocks of Victoria Island, Arctic Archipelago, Canada. Precambrian Research, 1(1): 13-41.

Young, G.M., 1981. The Amundsen embayment, Northwest Territories; relevance to the upper Proterozoic evolution of North America, Symposium on Proterozoic Basins of Canada, Halifax, Nova Scotia, Canada, pp. 203-218. 


\section{Appendix 1: Stratigraphic sections}

Table A1: Locations of stratigraphic sections and important stations

\begin{tabular}{|l|l|l|}
\hline Station & Latitude & Longitude \\
\hline 10DTS1 & $71^{\circ} 32^{\prime} 3.63^{\prime \prime} \mathrm{N}$ & $115^{\circ} 58^{\prime} 20.65^{\prime \prime} \mathrm{W}$ \\
\hline 10DTS2 & $71^{\circ} 26^{\prime} 2.14^{\prime \prime} \mathrm{N}$ & $116^{\circ} 7^{\prime} 41.04^{\prime \prime} \mathrm{W}$ \\
\hline GNME 06-03 & $71^{\circ} 37^{\prime} 41.87^{\prime \prime} \mathrm{N}$ & $115^{\circ} 53^{\prime} 46.36^{\prime \prime} \mathrm{W}$ \\
\hline 11JPS1 & $71^{\circ} 15^{\prime} 14.76^{\prime \prime} \mathrm{N}$ & $115^{\circ} 18^{\prime} 49.38^{\prime \prime} \mathrm{W}$ \\
\hline 11JPS2 & $71^{\circ} 17^{\prime} 6.02^{\prime \prime} \mathrm{N}$ & $115^{\circ} 35^{\prime} 34.09^{\prime \prime} \mathrm{W}$ \\
\hline 11JPS3 & $1^{\circ} 16^{\prime} 19.70^{\prime \prime} \mathrm{N}$ & $115^{\circ} 33^{\prime} 54.29^{\prime \prime} \mathrm{W}$ \\
\hline 11JPS4 & $71^{\circ} 8^{\prime} 54.50 " \mathrm{~N}$ & $115^{\circ} 6^{\prime} 37.38^{\prime \prime} \mathrm{W}$ \\
\hline 11JPS5 & $71^{\circ} 8^{\prime} 56.88^{\prime \prime} \mathrm{N}$ & $116^{\circ} 16^{\prime} 15.69^{\prime \prime} \mathrm{W}$ \\
\hline 11JPS8 & $72^{\circ} 7^{\prime} 51.45^{\prime \prime} \mathrm{N}$ & $112^{\circ} 15^{\prime} 25.62^{\prime \prime} \mathrm{W}$ \\
\hline 11RATRR031 & $71^{\circ} 6^{\prime} 52.14^{\prime \prime} \mathrm{N}$ & $115^{\circ} 26^{\prime} 58.18^{\prime \prime} \mathrm{W}$ \\
\hline 11RATJP048 & $71^{\circ} 9^{\prime} 5.72^{\prime \prime} \mathrm{N}$ & $115^{\circ} 8^{\prime} 23.68^{\prime \prime} \mathrm{W}$ \\
\hline
\end{tabular}


Lithologic Legend to Stratigraphic Sections

\begin{tabular}{|c|c|c|}
\hline Lithofacies & Name & Symbol \\
\hline 1 i) & $\begin{array}{l}\text { Gypsiferous claystone } \\
\text { /siltstone } \\
\text { Chickenwire } \\
\text { gypsum/anhydrite } \\
\text { Dolomitic wackestone and } \\
\text { grainstone }\end{array}$ & \\
\hline 1 ii) & $\begin{array}{l}\text { Bedded gypsarenite } \\
\text { Grainstone and dolomitic } \\
\text { grainstone with gypsum } \\
\text { pseudomorphs }\end{array}$ & 高 \\
\hline 1 iii) & Selenite beds & \\
\hline 2 & $\begin{array}{l}\text { Mudstone to grainstone } \\
\text { Dolomitic mudstone to } \\
\text { grainstone }\end{array}$ & \\
\hline 3 & $\begin{array}{l}\text { Stromatolitic carbonate } \\
\text { Finely laminated } \\
\text { limestone }\end{array}$ & \\
\hline 4 & $\begin{array}{l}\text { Rhythmically interbedded } \\
\text { mudstone and marl } \\
\text { Black shale }\end{array}$ & \\
\hline 5 & $\begin{array}{l}\text { Red/ Green Shales } \\
\text { and siltstones }\end{array}$ & \\
\hline 6i) & $\begin{array}{l}\text { Laminated siltstone with } \\
\text { halite casts }\end{array}$ & \\
\hline 6 ii) & $\begin{array}{l}\text { Dune/ ripple cross laminted } \\
\text { quartz arenite } \\
\text { Plane Bedded quartz arenite }\end{array}$ & \\
\hline 6 iii) & $\begin{array}{l}\text { Laminated couplets of } \\
\text { silt and sand }\end{array}$ & $=$ \\
\hline 6 iv) & $\begin{array}{l}\text { Massively bedded claystone/ } \\
\text { siltstone }\end{array}$ & \\
\hline 7 & $\begin{array}{l}\text { Tan carbonate } \\
\text { Flat pebble conglomerate }\end{array}$ & \\
\hline & Diabase/Gabbro & \\
\hline & Crystal tuff & \\
\hline & Covered interval & \\
\hline
\end{tabular}

$\underline{\text { Key to sedimentary structure symbols }}$

\begin{tabular}{|c|c|}
\hline Name & Symbol \\
\hline Satinspar & पाII \\
\hline Halite cast & $\square$ \\
\hline $\begin{array}{c}\text { Hummocky } \\
\text { cross-stratification }\end{array}$ & ACS \\
\hline Sand lens & \\
\hline Carbonate nodule & \\
\hline Molar-tooth structure & \\
\hline Selenite crystals & \\
\hline Dessication crack & \\
\hline Gypsum/anhydrite nodule & \\
\hline Teepee structure & \\
\hline $\begin{array}{l}\text { Elevated pyrite } \\
\text { concentration }\end{array}$ & \\
\hline Chert & $\mathrm{nt}$ \\
\hline Rip-up clasts & \\
\hline Load cast & \\
\hline Scour & \\
\hline Ripple cross-lamination & \\
\hline
\end{tabular}




\section{DTS1}

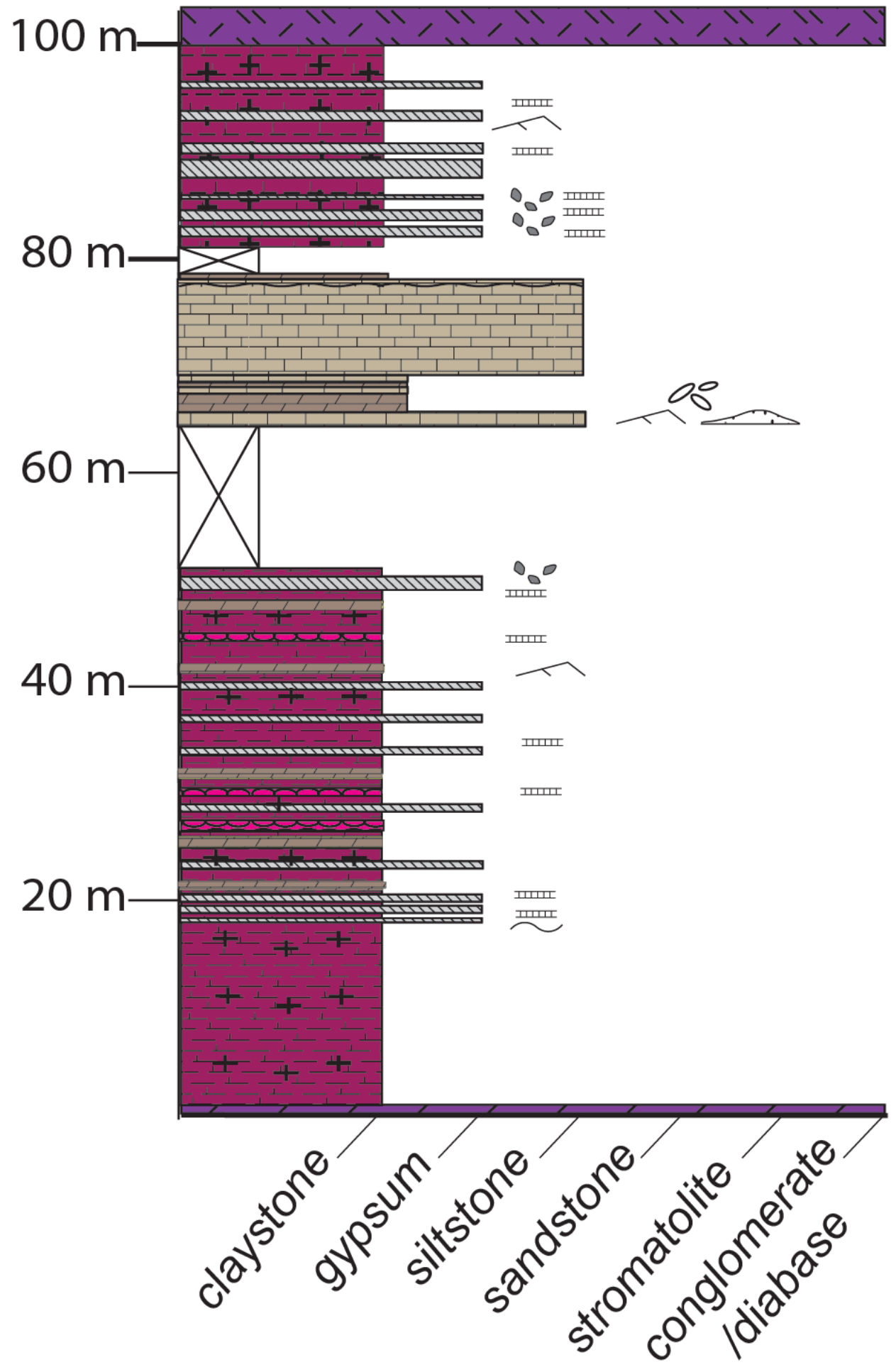




\section{DTS2}

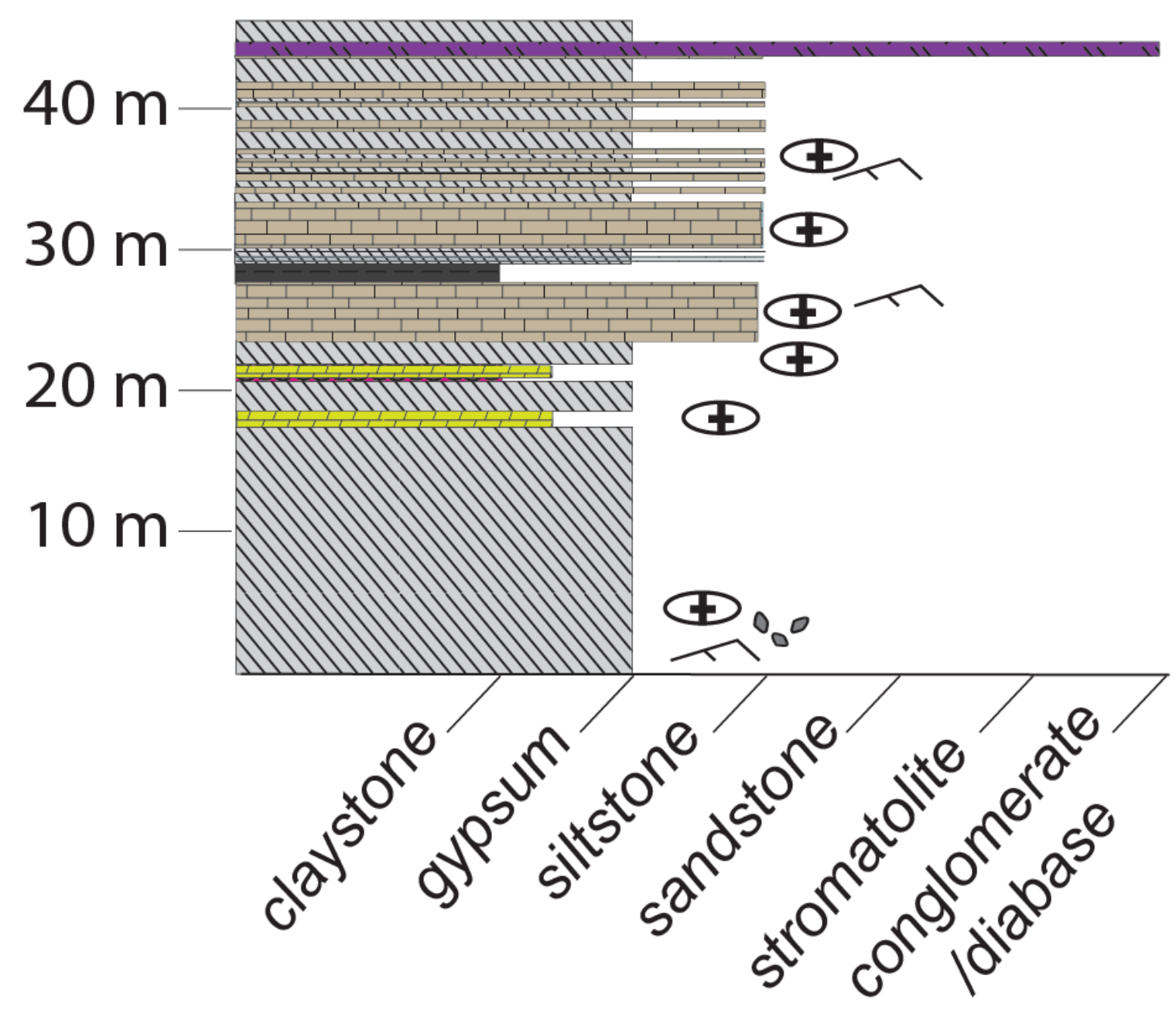


GNME 06-03

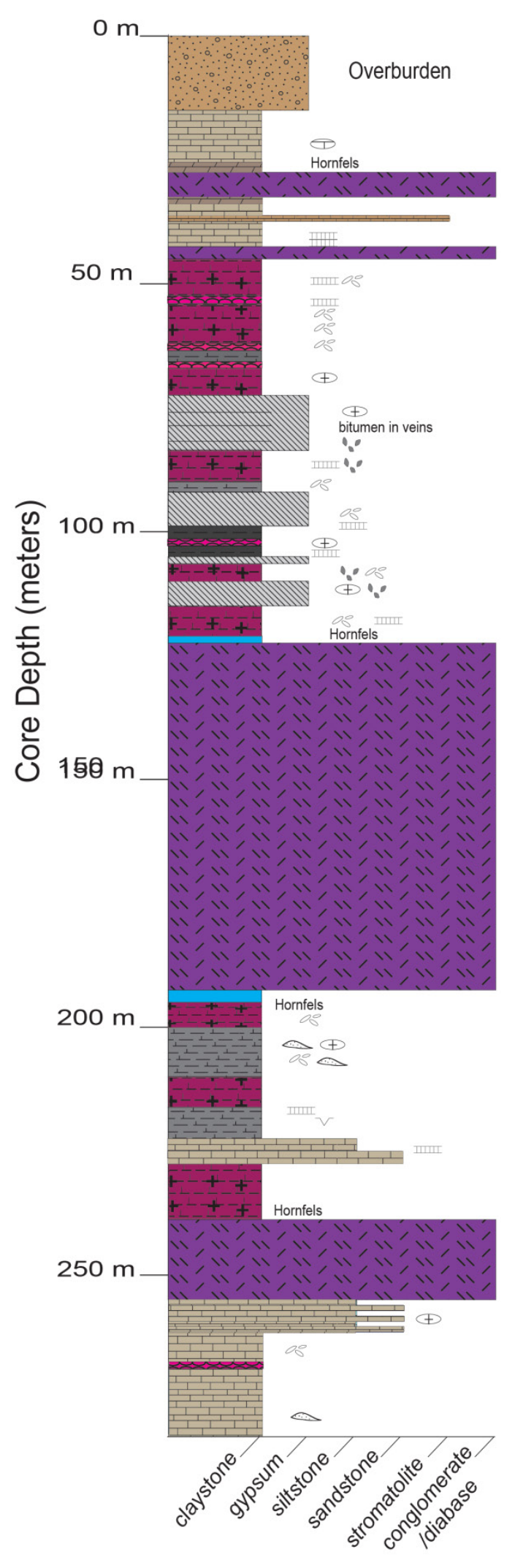




\section{JPS8}

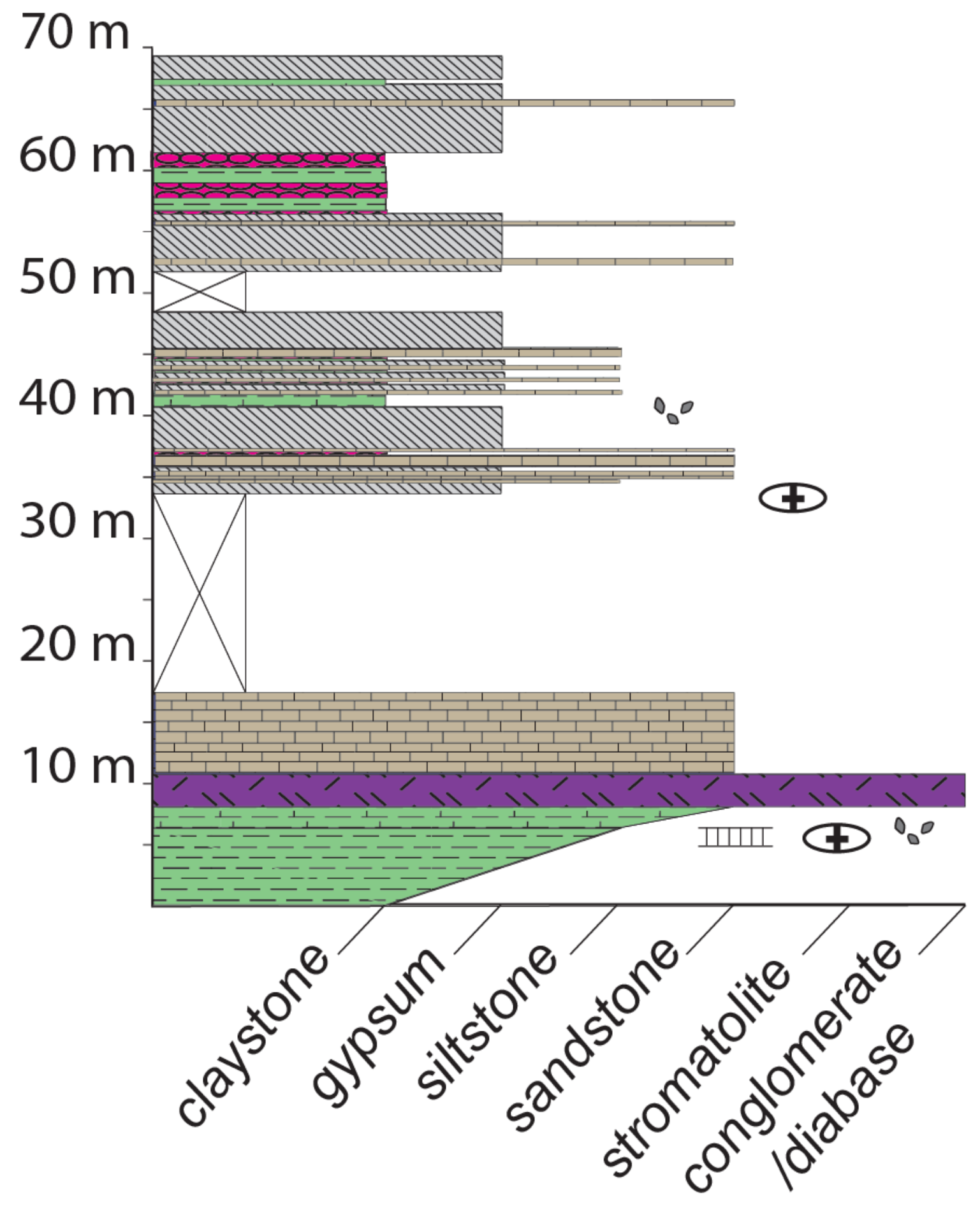




\section{JPS1}

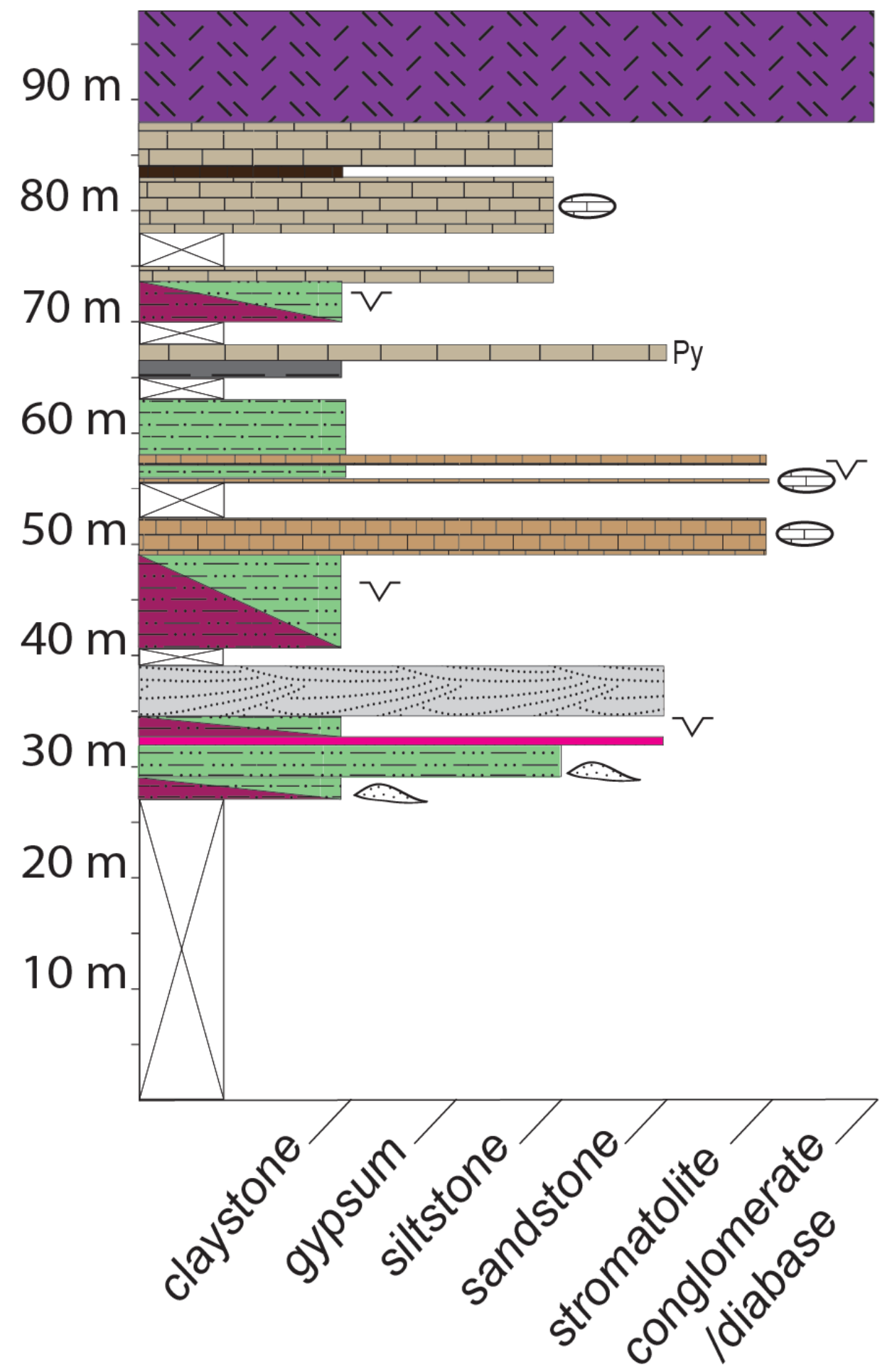


11JPS2

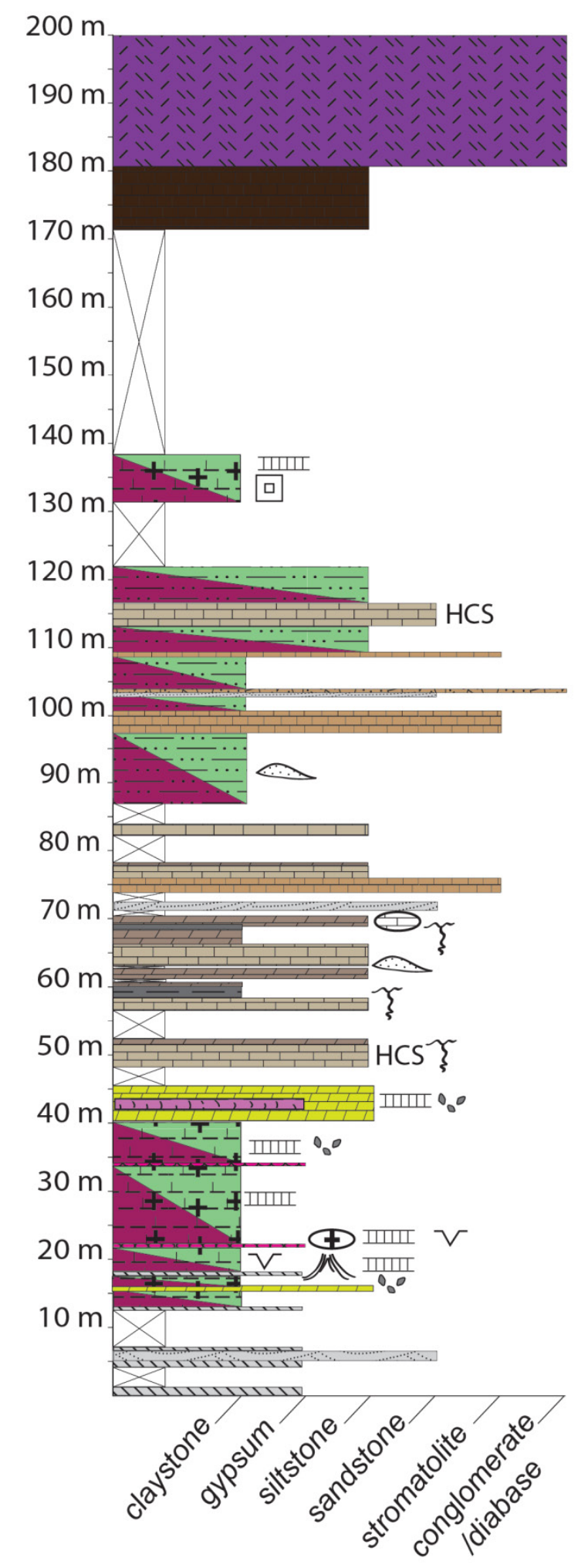




\section{JPS3}

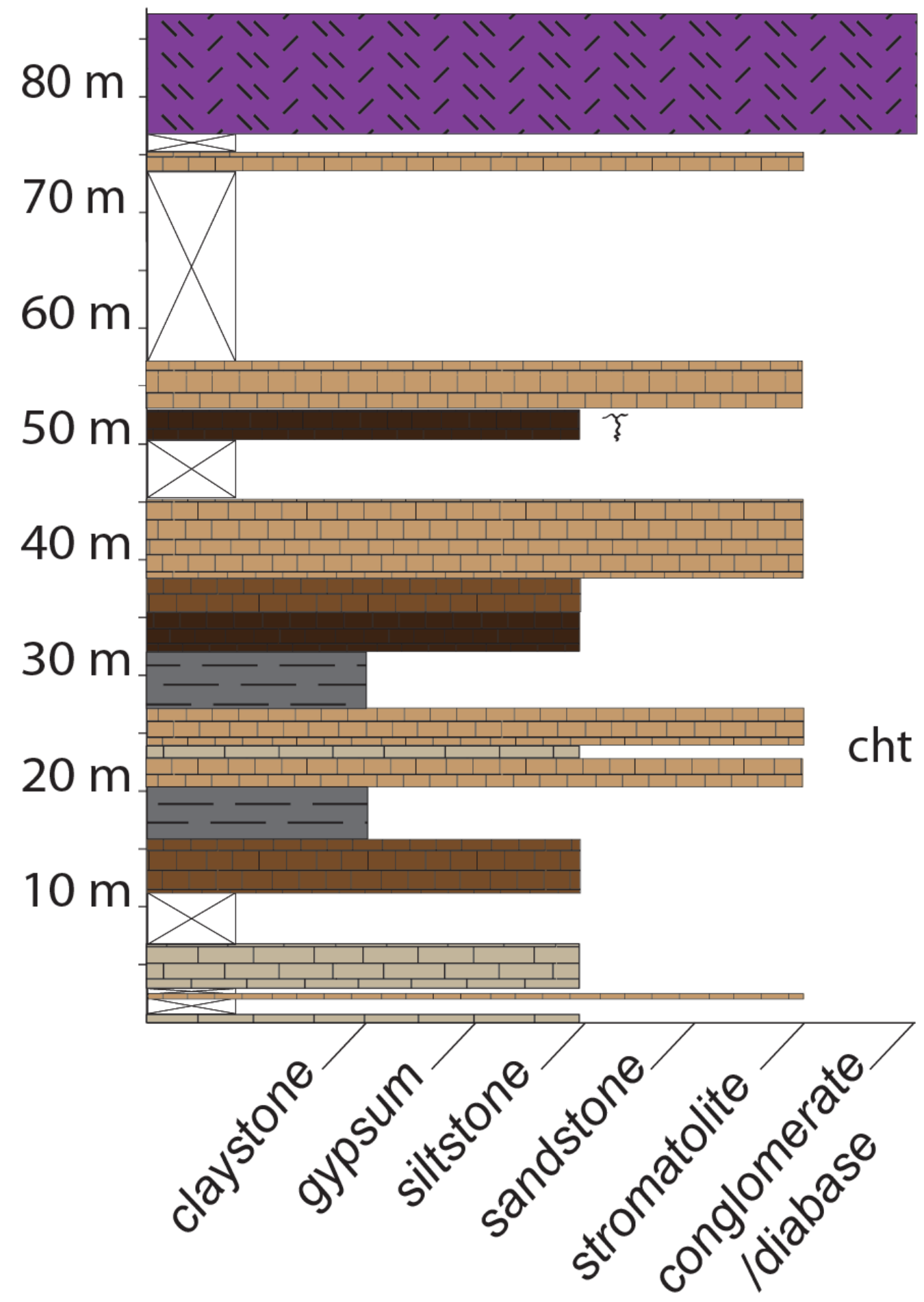




\section{JPS4}

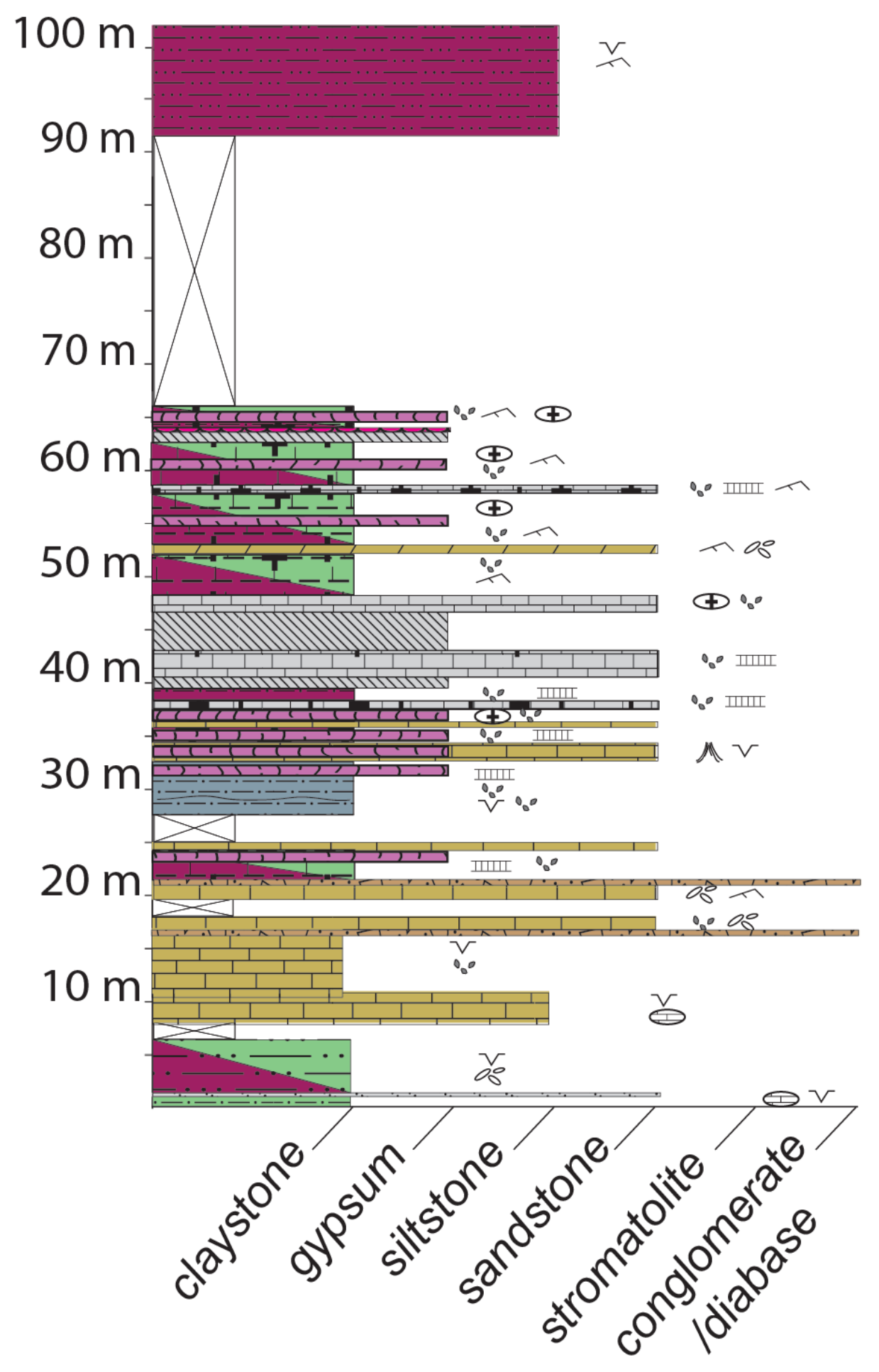




\section{JPS5}

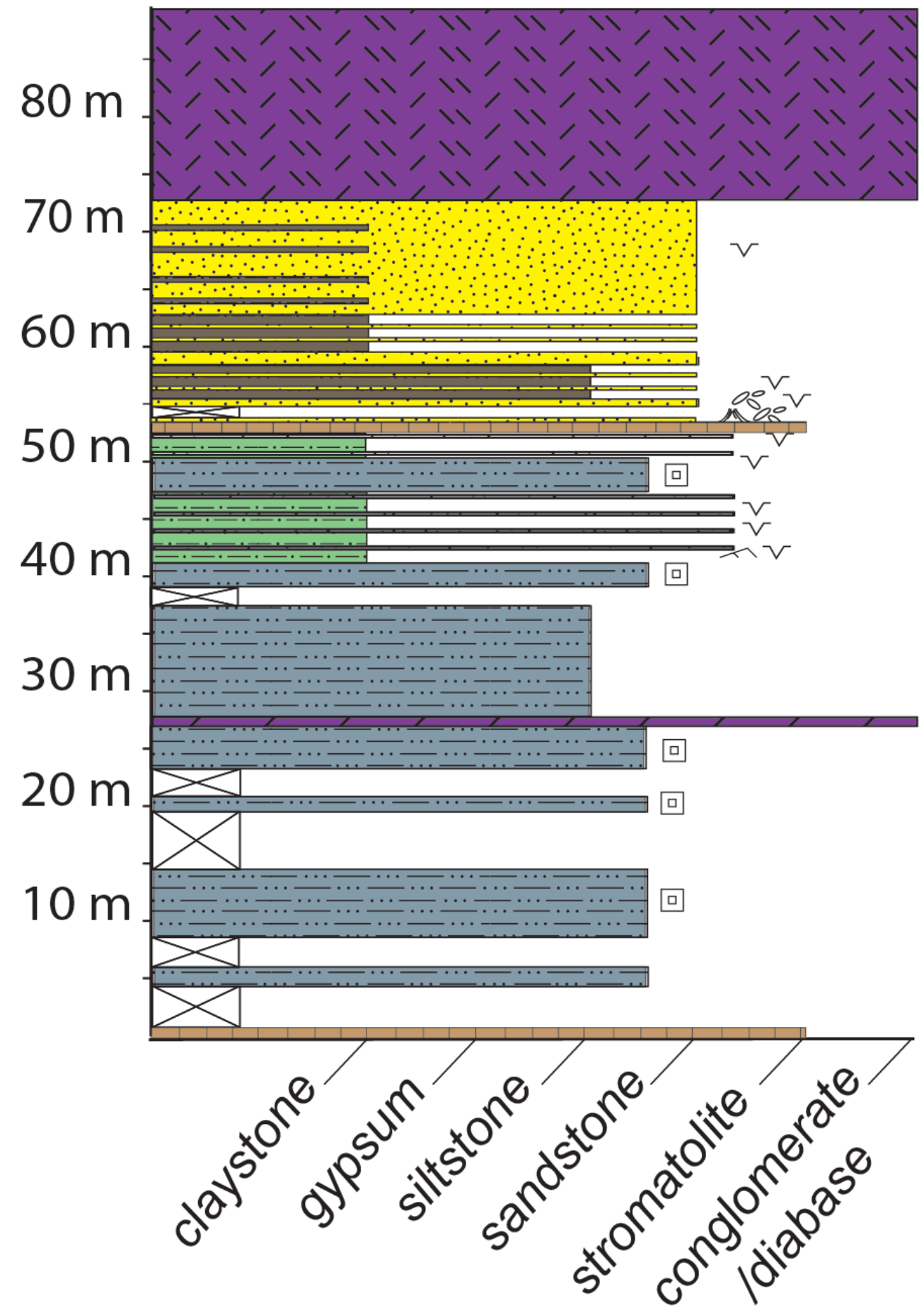




\section{JPS6}

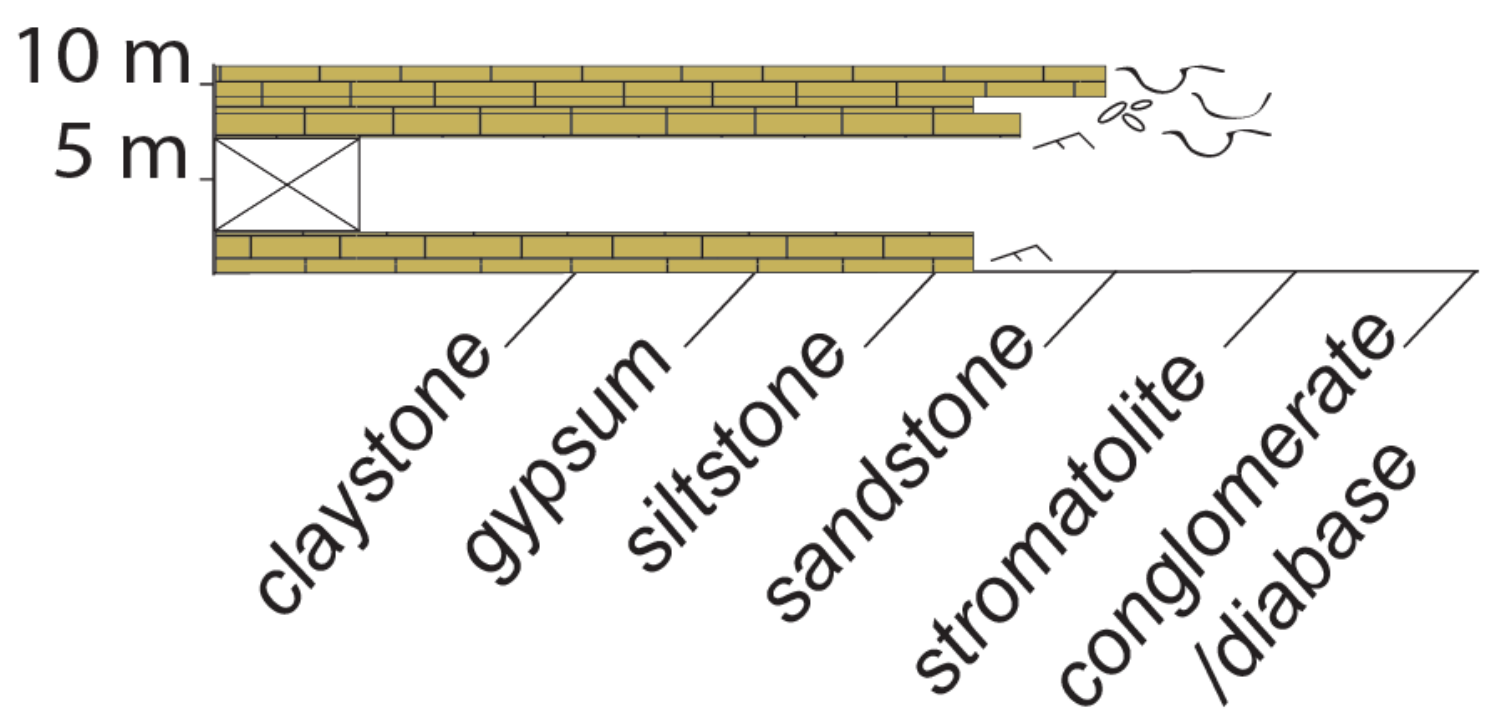




\section{Appendix 2}

\section{CAS analytical procedure}

1) Rock samples were trimmed to remove weathered surfaces and veins, cut into small pieces, rinsed with water and dried, then crushed.

2) Rock chips were rinsed once with DI water and again with mili-Q water then left to dry. The rock chips were then powdered by tungsten carbide disc grinder. Inter-sample contamination during grinding was mitigated by thoroughly cleaning the disc grinder between samples with ethanol then by running the grinder with pure quartz. A small aliquot of the next sample was then ground and discarded before proceeding.

3) Approximately $300 \mathrm{~g}$ of powder was weighed and added to an Erlenmeyer flask.

4-a) Each sample was rinsed for $24 \mathrm{Hrs}$ in a $10 \% \mathrm{NaCl}$ solution to remove any readily dissolvable $\mathrm{SO}_{4}$ (not bound in the carbonate lattice) (Kampschulte et al., 2001)

4-b) Samples were decanted before a second 24 hour rinse in $1000 \mathrm{~mL}$ of distilled water. 4-c) Any samples that had visible disseminated pyrite were subjected to an additional 24 hour rinse in an $\mathrm{H}_{2} \mathrm{O}_{2}$ solution, to oxidize any sulphide prior to sample dissolution. In these cases the samples were rinsed two more times in distilled water for 24 hours each. 
5) $6 \mathrm{~N} \mathrm{HCl}$ was slowly added to each sample and allowed to react. Flasks were stirred constantly in order to maximize the efficiency of the reaction and minimize pyrite oxidation during dissolution (Marenco et al., 2008). On average a total of $900-1000 \mathrm{ml}$ of $6 \mathrm{~N} \mathrm{HCl}$ solution was added before the reaction went to completion ( $6 \mathrm{~mol} \mathrm{HCl}$ is required to dissolve $300 \mathrm{~g}(\sim 3 \mathrm{~mol}) \mathrm{CaCO}_{3}$ according to the chemical reaction $2 \mathrm{HCl}_{(I)}+$ $\left.\mathrm{CaCO}_{3(\mathrm{~s})} \rightarrow \mathrm{CaCl}_{2(\mathrm{aq})}+\mathrm{CO}_{2(\mathrm{~g})}+\mathrm{H}_{2} \mathrm{O}_{(\mathrm{l})}\right)$. The average time for the reaction was $\sim 7$ hours 20 minutes.

6) The solution was centrifuged and filtered through a $.45 \mu \mathrm{m}$ vacuum filtration system to separate the liquid from the insoluble residue.

7) Barite $\left(\mathrm{BaSO}_{4}\right)$ was precipitated by adding $125 \mathrm{~mL}$ of $250 \mathrm{~g} / \mathrm{L} \mathrm{BaCl}$ solution to each sample. Completion of the precipitation reaction was ensured by adding excess $\mathrm{BaCl}$ solution (enough to precipitate $35 \mathrm{~g} \mathrm{BaSO}_{4}$ ). Samples were left to react for 24 hours.

8) Barite was isolated by filtering the solution, through $0.45 \mu \mathrm{m}$ filters then dried and weighed so that CAS concentrations could be calculated. If any iron chloride complexes had precipitated out of the acid solution they also were filtered out with the barite and thus an exaggerated weight of barite would be given. The percentage of barite remaining can be estimated by the $\mathrm{Ag}_{2} \mathrm{~S}$ yield in the following step.

9) The sulphate concentrated in the above steps was converted to $\mathrm{Ag}_{2} \mathrm{~S}$ following the procedure of Thode et al. (1961). Approximately 30mg of barite for the was added to a boiling flask along with 15-20ml of "Thode solution" see Thode et al. (1961). This mixture was heated to near boiling to completely reduce the sulphate (in $\mathrm{BaSO}_{4(\mathrm{~s})}$ ) to 
hydrogen sulphide gas. The $\mathrm{H}_{2} \mathrm{~S}$ gas was forced through a zinc acetate trap where the sulphur in the hydrogen sulphide bonded with zinc and was precipitated as zinc sulphide (ZnS). When the reaction had gone to completion (all $\mathrm{SO}_{4}$ had reacted to $\mathrm{H}_{2} \mathrm{~S}$ ) silver nitrate $\left(\mathrm{AgNO}_{3(\mathrm{aq})}\right)$ was added to the $\mathrm{ZnS}$ to precipitate silver sulphide $\left(\mathrm{Ag}_{2} \mathrm{~S}_{(\mathrm{s})}\right)$.

9-b) The $\mathrm{Ag}_{2} \mathrm{~S}$ was dried in an oven for $24 \mathrm{hrs}$ and weighed to verify yields. A small amount of $\mathrm{Ag}_{2} \mathrm{~S}(3 \mathrm{mg})$ was weighed and wrapped delicately in sterilized aluminum foil.

10) $\mathrm{SF}_{6}$ line (see Figure $\mathrm{A} 1$, below): The small packets of $\mathrm{Ag}_{2} \mathrm{~S}$ were placed into a "bomb", pressurized with Argon gas, which was then sealed. The Argon gas was vacuumed out and the bombs were tested for leaks. Each bomb was filled to a pressure of approximately 95 torr with Fluorine gas $\left(F_{2}\right)$ then heated to $225^{\circ} \mathrm{C}$ for $12 \mathrm{hrs}$. This allowed the $F_{2}$ to fully react with the $\mathrm{Ag}_{2} \mathrm{~S}$ to form sulphur hexafluoride gas $\left(\mathrm{SF}_{6}\right)$. Valves 4,5 and 6 were opened to allow the gas to flow through the junk trap (held at $-120^{\circ} \mathrm{C}$ ), the $\mathrm{SF}_{6}$ trap (held at $-196^{\circ} \mathrm{C}$ ) and the $\mathrm{KBr}$ trap. The junk trap allowed any unreacted $\mathrm{F}_{2}$ and $\mathrm{SF}_{6}$ product to flow through but froze any non-SF 6 product in the trap. The sample trap allowed the unreacted $F_{2}$ to flow through but froze any $S F_{6}$ product. The $F_{2}$ gas, which is highly corrosive, passed through the potassium bromide (KBr) trap where it reacted to form an inert compound $\left(\mathrm{KF}_{(\mathrm{s})}\right)$ and released bromine gas, which was subsequently frozen in the $\mathrm{Br}$ trap. When the pressure dropped to zero on P1 valves 4, 5 and 6 were closed and the $\mathrm{SF}_{6}$, held in the sample trap was heated to room temperature. In order to further purify the $\mathrm{SF}_{6}$ it was passed through a gas chromatograph (GC), valve 8 was opened to allow the sample into the GC. Initially valve 
9 was left open to allow any non-SF 6 to escape but when the $\mathrm{SF}_{6}$ peak was detected valve 9 was closed and valves 10 and 11 were opened to both trap the sample and allow any non-condensable gas (eg. Helium) through to the vacuum. When the pressure on P2 reached zero valves 10 and 11 were closed, the $\mathrm{SF}_{6}$ was heated back to room temperature and the pressure of $\mathrm{SF}_{6}$ was measured before valve 12 was opened to allow the gas into the Mass Spectrometer.

11) The samples were analyzed on a Thermo Scientific Mat 253 mass spectrometer fitted with a dual inlet (sample and standard) capable of high precision multiple sulphur isotope measurements.

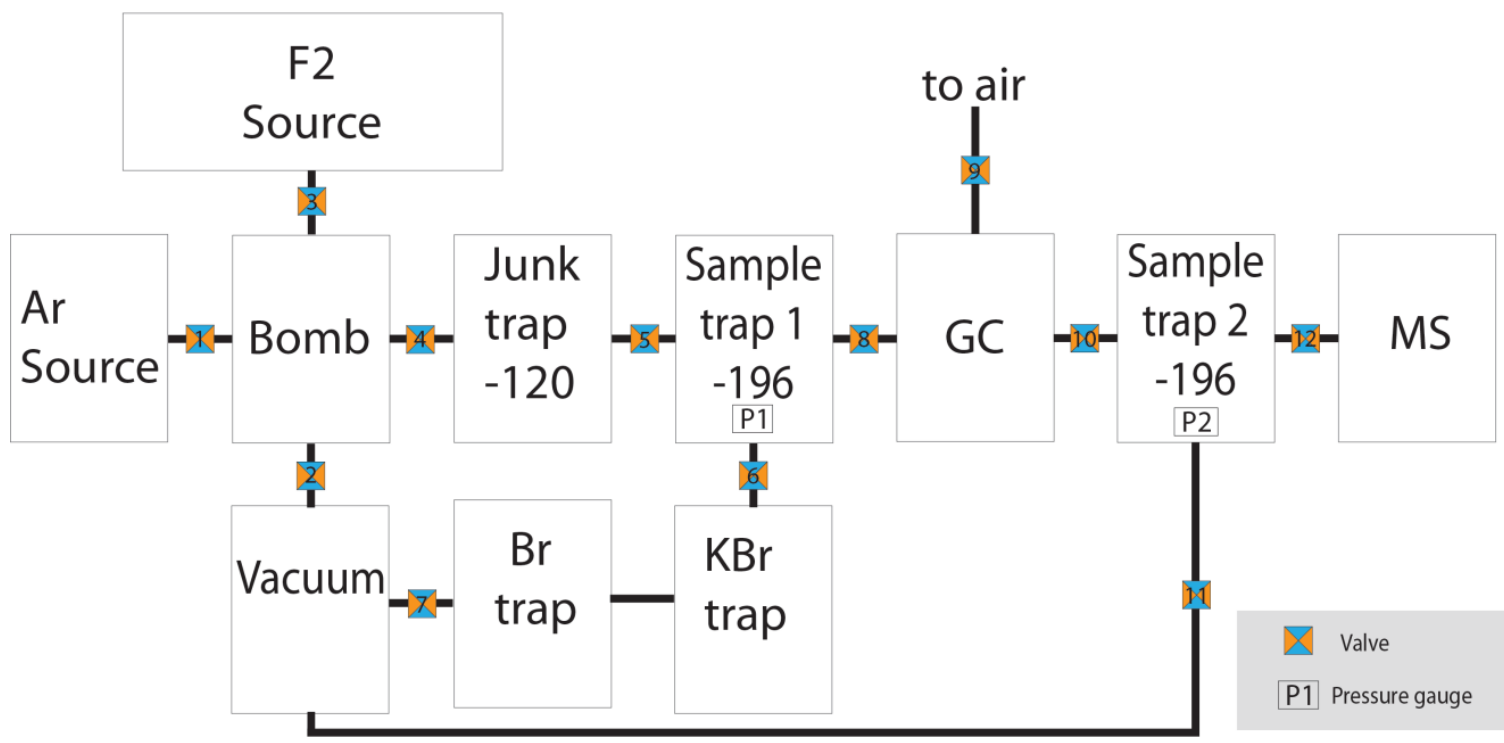

Figure $\mathrm{A} 2: \mathrm{SF}_{6}$ line 